\title{
Adriana Novaes Rodrigues
}

Incidência e fatores de risco de contaminação por fungos filamentosos na mucosa oral de trabalhadores rurais das culturas de cana-de-açúcar, laranja e abacaxi da região de Frutal-MG

Tese apresentada à Faculdade de Medicina da Universidade de São Paulo, para obtenção do título de Doutor em Ciências.

Programa de Patologia

Orientador: Prof. Dr. Alfésio Luís Ferreira Braga

EDIÇÃO CORRIGIDA 


\section{Adriana Novaes Rodrigues}

Incidência e fatores de risco de contaminação por fungos filamentosos na mucosa oral de trabalhadores rurais das culturas de cana-de-açúcar, laranja e abacaxi da região de Frutal-MG

Tese apresentada à Faculdade de Medicina da Universidade de São Paulo, para obtenção do título de Doutor em Ciências.

Programa de Patologia

Orientador: Prof. Dr. Alfésio Luís Ferreira Braga

EDIÇÃO CORRIGIDA - Original disponível na Biblioteca USP.

(ART. 5 da Resolução CoPGr - 6018 - de 13 Outubto 2911) 
Dados Internacionais de Catalogação na Publicação (CIP)

Preparada pela Biblioteca da

Faculdade de Medicina da Universidade de São Paulo

Creprodução autorizada pelo autor

\section{Rodrigues, Adriana Novaes}

Incidência e fatores de risco de contaminação por fungos filamentosos na mucosa oral normal de trabalhadores rurais das culturas de cana-de-açúcar, laranja e abacaxi da região de Frutal-MG / Adriana Novaes Rodrigues. -- São Paulo, 2016.

Tese(doutorado)--Faculdade de Medicina da Universidade de São Paulo. Programa de Patologia.

Orientador: Alfésio Luís Ferreira Braga.

Descritores: 1.Epidemiologia 2.Fungos filamentosos 3.Trabalhadores rurais 4.Saúde ocupacional 5.Patologia bucal 6.Fungos/patogenicidade 7.Infecção fúngica 


\section{DEDICO}

À minha mãe Rita Novaes Rodrigues (in memoriam) que agora sabe que a vida continua - sempre fazemos o melhor que sabemos - te amo mãe! Tudo que sou devo a você!

Às minhas filhas (Três Marias):

- Maria Luiza (in memoriam), tudo começou com um pedido de mestrado e chegamos juntas até aqui. Mar do meu mundo, sol da minha eternidade!

- Maria Fernanda, coração generoso, caridoso e afável, obrigada pelas orações nos momentos difíceis. Raio de luz vindo de Deus!

- Maria Julia, doce, caridosa e determinada, quando eu crescer, eu quero conseguir rezar como você. Preciosa harmonia no meu coração!

Ao meu marido João Maluf Franco, companheiro de todas as horas, nunca me deixou desistir, amigo de outras vidas - te agradeço por cada momento.

Ao meu querido irmão João Ozório Rodrigues Neto, meu orientador desde pequena, sem você eu não teria conseguido, abaixo de Jesus é o maior médico que já conheci: sábio, simples e dedicado.

À minha cunhada Chames Maluf - irmã que sempre pude contar, mesmo nos momentos mais loucos.

Às amigas eternas - Eunice Marques Silva, Eusamar Antunes Bernardes e Andreia Ferreira - por não terem medido esforços para me ajudar, muitos risos, muitas lágrimas, muitas histórias - irmãs de coração.

Ao Prof. Dr. Sir Arthur Eddington (in memoriam) - Compartilho de sua ideia "Sem Deus não há ciência" - Hoje podemos provar através de suas teorias, que a mediunidade está diretamente ligada à força eletromagnética. 


\section{AGRADECIMENTOS}

A Deus, pelo Amor incondicional e Paciência extrema, tornando as dificuldades insignificantes.

Meu profundo agradecimento ao meu orientador Prof. Dr. Alfésio Luís Ferreira Braga. Registro aqui em palavras o meu apreço pela oportunidade e apoio, que sempre me dedicou.

Ao Prof. Dr. Josias Andrade Sobrinho (in memoriam), meu orientador de mestrado e ao Prof. Dr. Odilon Victor Porto Dedardini, por terem me reintroduzido na pesquisa.

À Prof. Dra. Cristiane Gorgati Guidorene, que além de decifrar os enigmas mais difíceis desta pesquisa, resumiu a vida de um professor, quando disse "... ensino porque eu gosto".

Aos voluntários (anônimos) desta pesquisa, que aceitaram deixar um pedacinho de suas vidas marcadas para a ciência.

Aos amigos Wagner Guidi, Vera Lucia Farias, Rodrigo Hidalgo Mendonça e Alexandre Faria - continuamos a escrever nossa história.

Ao amigo e funcionário Thiago Luiz Vieira Rezende, por toda ajuda durante a execução desta meta junto a USP. Serei eternamente grata!

Ao editor de layout dos Cadernos UNIFOA, Laert dos Santos Andrade por me ensinar a preciosa arte dos gráficos.

Aos amigos e funcionários das usinas, dos campos de cana-de-açúcar, dos campos de laranja e de abacaxi, que colaboraram para execução da pesquisa.

Aos amigos e funcionários da UEMG - Campus Frutal.

Aos meus mentores Solano e Meimei - eu sei o quanto deve ser difícil me ajudar - Obrigada a vocês e a todos os irmãos espirituais que me auxiliam em minha jornada pele Terra. 
“Deus!

...dai ao viajor a Estrela Guia, ao aflito a consolação, ao doente o repouso..."

Prece de Caritas 


\section{SUMÁRIO}

Lista de figuras

Lista de tabelas

Resumo

Abstract

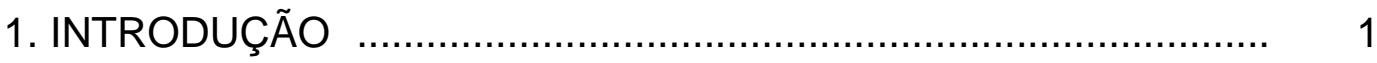

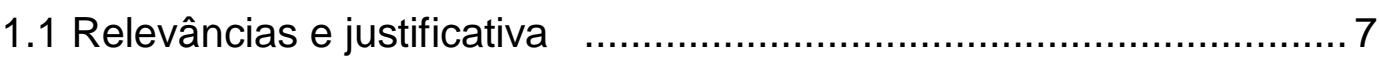

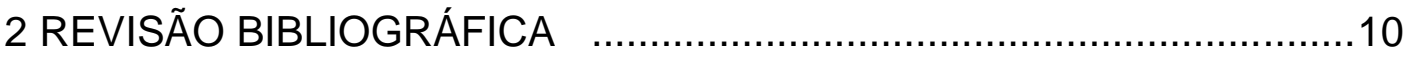

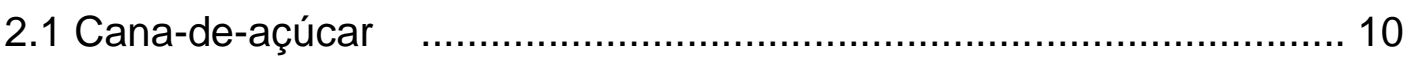

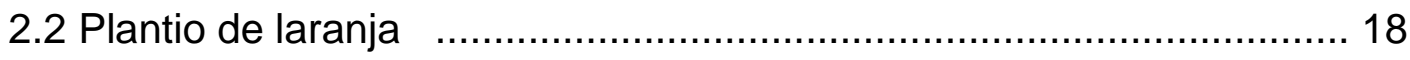

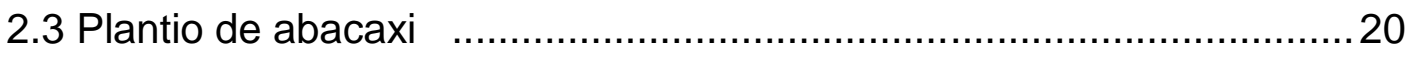

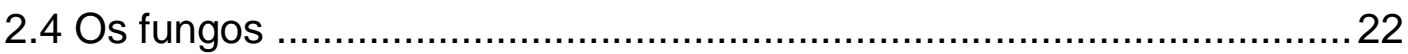

2.4.1 Alguns gêneros de fungos filamentosos de importância

Clínica

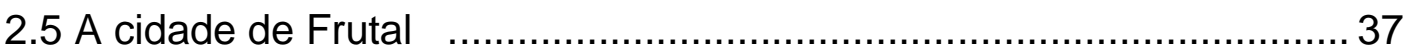

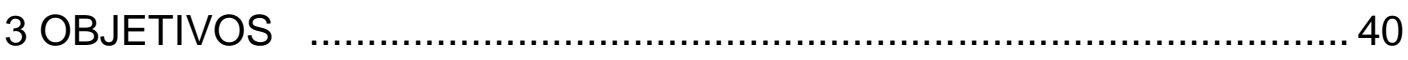

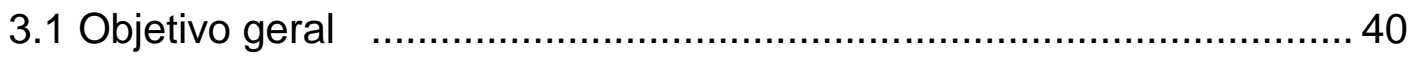

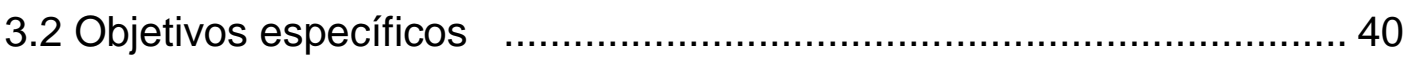

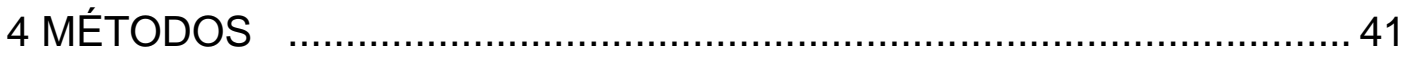

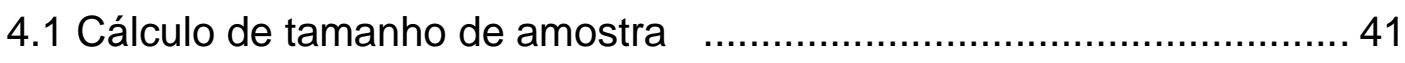

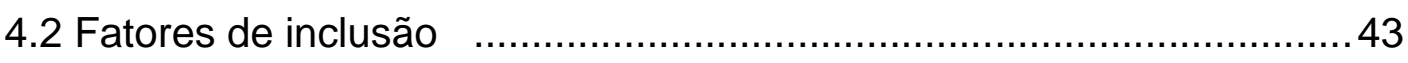

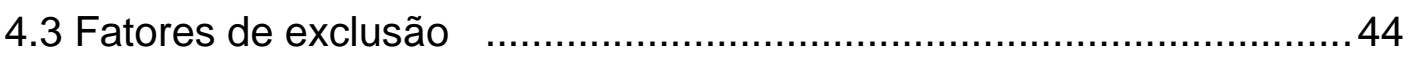

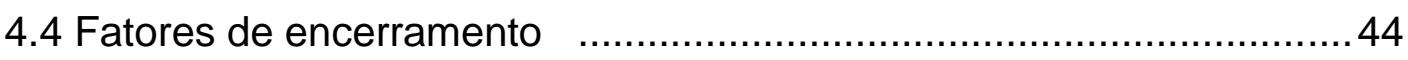

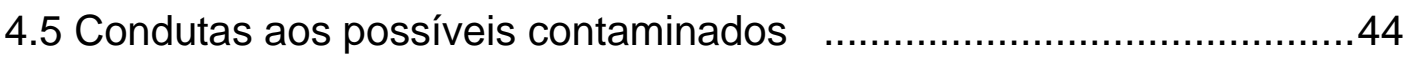

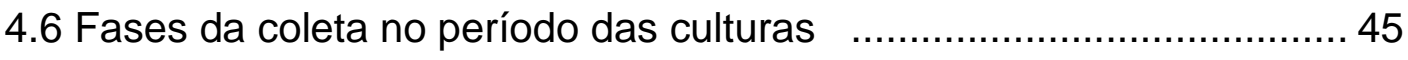




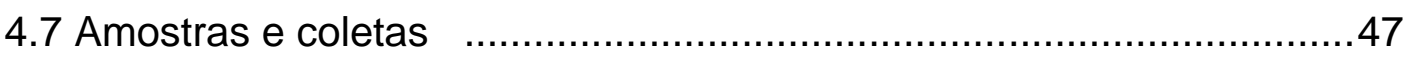

4.8 Exame do meio ambiente …........................................................... 49

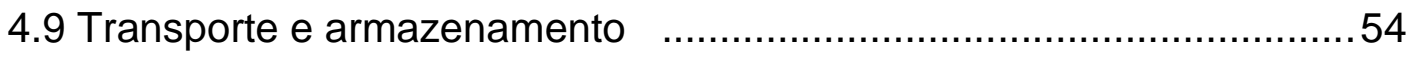

4.10 Identificação de fungos filamentosos ………...................................54

4.11 Procedimentos para cultura ………………............................... 55

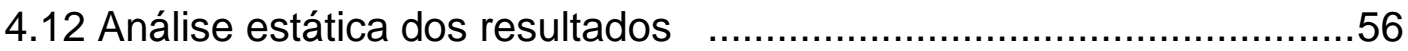

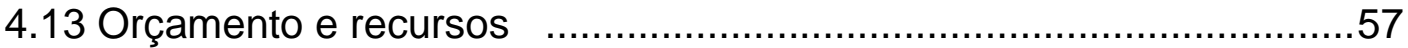

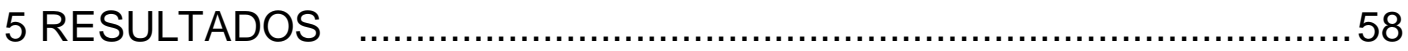

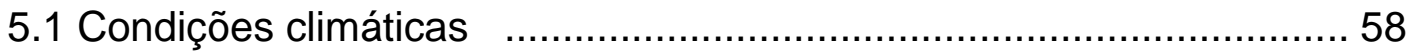

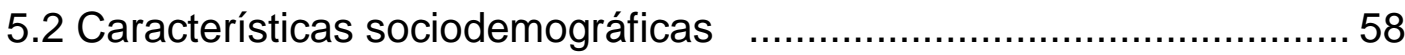

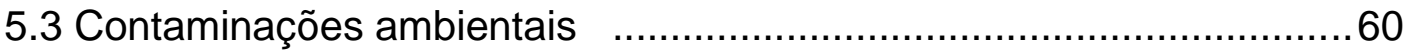

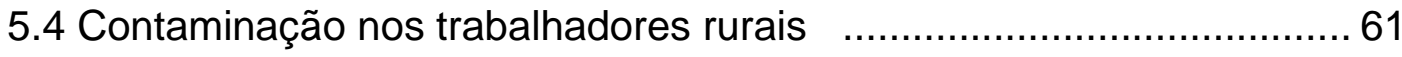

5.4.1 Riscos de contaminação nos trabalhadores rurais ...............64

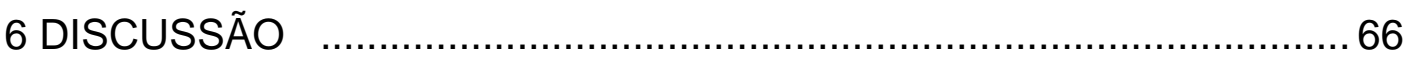

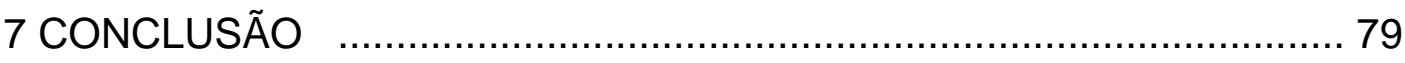

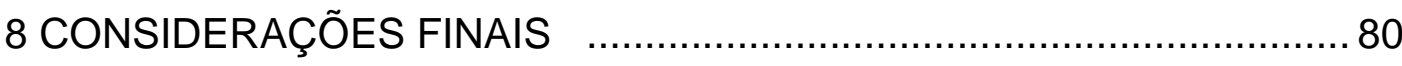

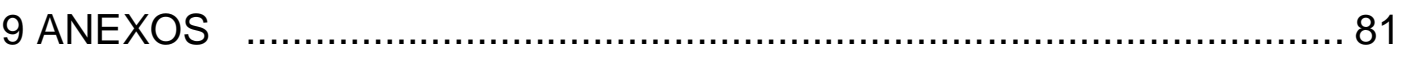

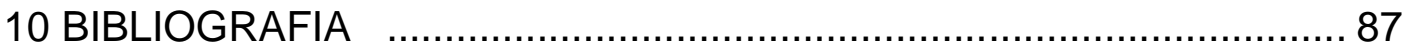




\section{LISTA DE FIGURAS}

Figura 1 Etapas do processo produtivo da cana no setor sucroalcooleiro

Figura 2 Plantadeira PMA 1800 - Wagner Guidi-2014

Figura 3 Mostra esquematicamente o ciclo de reprodução assexuada dos fungos filamentosos

Figura 4 Turma do Curso de Aplicação de 1913-1914 do Instituto Oswaldo Cruz

Figura 5 Contaminação da cana-de-açúcar em planta adulta

Figura 6 Localização da cidade de Frutal

Figura 7 Localização da cidade de Frutal na Macrorregião

Figura 8 Fluxo do estudo na linha-tempo

Figura 9 Produto usado como meio de cultura para fungos

Figura 10 Placa de exposição ambiental na cultura de laranja

Figura 11 Distribuição das placas de Petri nos campos das culturas

Figura 12 Percentagem de placas de Petri contaminadas nos tempos de estudo definidos nesta pesquisa

Figura 13 Número de colônias encontradas como contaminantes nos três tempos de análise nas culturas e no meio ambiente

Figura 14 Número de trabalhadores que apresentaram contaminação fúngica, nos referentes tempos de observação do estudo

Figura 15 Placa com Aspergillus niger, após repique

Figura 16 Placas com Frente e Verso de A. niger.

Figura 17 Aspergillus niger (X100 LPCB: Nikon) 


\section{LISTA DE TABELAS}

Tabela 1 Análise descritiva das características demográficas e renda dos trabalhadores rurais. Teste Kruskal-Walis na cana-de-açúcar e abacaxi com $p>0,05$; 2-Teste Kruskal-Walis na laranja e abacaxi com $p>0,05$.

Tabela 2 Intervalos de confiança de odds ratio e 95\% para variáveis incluídas nos modelos individuais para investigar fatores de risco para infecção fúngica da mucosa oral. 


\section{RESUMO}

Rodrigues AN. Incidência e fatores de risco de contaminações por fungos filamentosos na mucosa oral de trabalhadores rurais das culturas de cana-deaçúcar, laranja e abacaxi da região de Frutal, MG [tese]. São Paulo: Faculdade de Medicina, Universidade de São Paulo; 2016.

RESUMO: Determinadas espécies de fungos são responsáveis por diversas doenças no ser humano. Estudos epidemiológicos avaliam essas infecções tanto superficiais quanto profundas, e alguns destes avaliam em relação ao trabalho e condição de vida e saúde de trabalhadores de diversas áreas. Entretanto a contaminação por fungos filamentosos na região da cavidade oral com relação à atividade laboral rural não apresenta referência. OBJETIVOS: Avaliar a incidência de contaminação fúngica na região orofaringe normal de trabalhadores agrícolas das culturas de cana-de-açúcar, laranja e abacaxi do município de Frutal, Minas Gerais. MÉTODOS: Esse é um trabalho longitudinal, prospectivo, tipo coorte, não randomizado, em que os participantes eram migrantes vindos para trabalho temporário nas culturas referidas. Foram selecionados 60 participantes no momento das contratações após realizados os exames pré-admissionais. Avaliou-se as características sociodemográficas dos participantes. A coleta de material investigativo seguiu a ordem: região do sulco gengivo - labial, próximo à região do freio superior e freio inferior; material da mucosa jugal direita e esquerda, com um swab para cada região e dispostos na placa de Petri, respeitando a anatomia descrita. A coleta e análise do material dos trabalhadores e do meio ambiente seguiram os tempos de cada cultura, determinados de (to), ( $\left.\mathrm{t}_{1}\right),\left(\mathrm{t}_{2}\right)$. Também foram usados para caracterizar cada fase de coleta, cultura e análise das amostras. As amostras foram semeadas em meio Agar Sabouraud Dextrose. Após o crescimento dos isolados, as culturas filamentosas foram submetidas às técnicas de colônias gigantes e microcultivo. Os fungos foram identificados no microscópio com objetiva de 40 vezes. RESULTADOS: Não houve diferença entre idade e sexo nos três grupos analisados. Houve predomínio de homens afrodescendentes nas culturas de cana e laranja quando comparados ao abacaxi, que apresentou um predomínio de caucasianos. Trabalhadores de origem oriental foram detectados apenas na cultura de abacaxi. Quanto à renda, os trabalhadores de abacaxi recebem salários mais elevados do que os outros dois grupos de trabalhadores. Não houve diferença em relação ao tabagismo e a ingestão de álcool entre os três grupos analisados. Em relação à contaminação do meio ambiente, tanto na planta quanto no ar, encontrou-se um maior índice de placas de Petri contaminadas nas plantações de abacaxi e cana-de-açúcar, respectivamente. Observou-se um predominio de $F$. moniliforme na cultura de cana-de-açúcar e de F.subglutians nas culturas de laranja e de abacaxi nos tempos definidos dessa pesquisa. A contaminação dos trabalhadores ocorreu no segundo tempo da pesquisa. A respeito dos voluntários das plantações de abacaxi, 13,3\% dos trabalhadores foram infectados entre os sessenta analisados; todos os trabalhadores foram contaminados com F.subglutinans. Na cultura de cana-deaçúcar, $8,3 \%$ deles foram encontrados infectados, sendo $5 \%$ por $A$. niger e 3,3\% por F.moniliforme. Dois voluntários infectados pelo $A$. niger apresentaram 
infecção concomitante com C. albicans. Na lavoura de laranja 1,6\% foram infectados por F.subglutians. CONCLUSÕES: Esse estudo demonstrou que trabalhar na cultura do abacaxi se mostrou um fator de risco para infecção fúngica na mucosa oral quando comparado às atividades na cultura da laranja. Houve também contaminação fúngica na cultura de cana-de-açúcar quando comparado ao grupo de referência. Outros fatores como idade, ingestão de álcool, tabagismo, renda familiar ou etnia não se mostraram estatisticamente significativos para incidência da infecção.

Descritores: epidemiologia; fungos filamentosos; trabalhadores rurais; saúde ocupacional; infecção fúngica; fungos /patogenicidade. 


\begin{abstract}
Rodrigues AN. Incidence and risk factors of contamination by filamentous fungi in the oral mucosa of rural workers in sugar cane, orange and pineapple crops in Frutal, MG [thesis]. São Paulo: "Faculdade de Medicina, Universidade de São Paulo"; 2016.
\end{abstract}

ABSTRACT: Certain species of fungi are responsible for several diseases in humans. Epidemiologic studies rate those infections, both superficial and profound, and some of them rate regarding the occupation and life and health conditions of workers from several areas. However, the filamentous fungal infection in the oral cavity regarding laboral activity presents no reference. OBJETIVE: To rate the incidence of fungal contamination in the normal oropharynx of agricultural workers of sugar cane, orange and pineapple crops in the municipal district of Frutal, Minas Gerais. METHODS: This is a longitudinal, prospective and cohort work, in which the participants were migrants to temporary work in the aforesaid crops. Sixty participants were selected in the hiring moment after pre-admission examinations. The participants' sociodemographic features were rated. The gathering of investigative materials followed the order: region of the gingival sulcus, close to the upper and lower lip curb region; material from the right and left jugal mucous with a swab for each region and arranged in a Petri dish, respecting the anatomy described. The gathering and analysis from workers and environment material followed the time of each culture, determined of (to), $\left(\mathrm{t}_{1}\right),\left(\mathrm{t}_{2}\right)$. They were also used to feature each stage of gathering, culture and analysis of samples. The samples were sown amid Sabouraud Dextrose Agar. After the growth of the isolates, the filamentous cultures were subjected to the techniques of giant colonies and microcultivation. The fungi were identified in the microscope with a 40x magnification. RESULTS: There was no difference between age and sex in the three groups studied. There was a predominance of African descent men in cane and orange crops compared to pineapple, which showed a predominance of Caucasians. Oriental workers were detected only in pineapple crop. As for income, the pineapple workers receive higher wages than the other two groups of workers. There was no difference regarding smoking and alcohol intake among the three groups analyzed. Regarding the environment contamination, both in the plant and in the air, a higher rate was found in Petri dishes contamined in pineapple and sugar cane crops, respectively. There was a predominance of $F$. moniliforme in the sugar cane crop and of $F$.subglutians in orange and pineapple crops in the times defined in this research. Contamination of workers occured in the second half of the research. Regarding the volunteers of pineapple crops, $13,3 \%$ workers were infected among the sixty analyzed; all workers were contamined with $F$. subglutinans. In the sugar cane crop, 8,3\% of them were found infected, $5 \%$ by $A$. niger and $3,3 \%$ by $F$. moniliforme. Two volunteers infected by the $A$. niger presented concomitant infection with $C$. albicans. A worker of the orange crop was infected $(1,6 \%)$ by $F$. subglutians. CONCLUSIONS: This study demonstrated that working in the pineapple crop showed a risk factor for the fungal infection in the oral mucosa when compared 
to the activities in the orange crop. Also, there was a fungal contamination in the sugar cane crop when compared to the reference group. Other factors such as age, alcohol intake, smoking, family income or ethnicity were not statistically significant for the incidence of infection.

Descriptors: epidemiology; filamentous fungi; rural workers; occupational health; pathology, oral; fungi/pathogenicity; fungus diseases. 


\section{INTRODUÇÃO}

Os fungos são organismos presentes na maioria dos biomas, tais como a água, plantas e animais, além de se desenvolverem em ambientes inóspitos como na Antártica (Barato, 2014) ou regiões desérticas (Gonçalves et al., 2016), com uma estimativa de cerca de 611.000 mil espécies (Mora et al., 2011), sendo que menos de $16 \%$ são descritos de sua totalidade (Kirk et al., 2008). Normalmente, os fungos são saprófitos em relação ao homem, porém, as alterações do meio ambiente, dos hábitos alimentares, do uso indevido de medicação, do aumento da expectativa de vida e do estado imunológico podem torná-los patogênicos (Rosa, 2013). Essa patogenicidade está associada à produção de substâncias designadas de micotoxinas, que são metabólitos secundários produzidos especialmente por espécies de fungos filamentosos dos gêneros Aspergillus, Fusarium e Penicillium (lamanaka et al., 2013). Com capacidade mutagênica e carcinogênica, as micotoxinas apresentam efeitos deletérios sobre a saúde humana e animal. Mais de 300 tipos de micotoxinas já foram identificadas, sendo consideradas como problema de saúde pública devido à gravidade das doenças que causam (Pereira et al., 2015).

Os fungos filamentosos fazem parte de microbiomas dos seres vivos (Clemente et al., 2012), no entanto, na designação de microbioma, está implícito a referência aos componentes comensais e bactérias patogênicas (Moyses, Naglik, 2012). A região da cavidade oral humana abriga o microbioma mais diversificado do corpo humano, e é composto de diversas associações de microorganismos incluindo vírus, fungos, protozoários e bactérias com mais de 700 espécies já detectadas (Wade, 2013). A cavidade bucal é a principal porta de entrada dos micro-organismos existentes no meio externo para o interior do organismo (Ghannoum, Mukherjee, 2013). A contiguidade dessa região com os locais vizinhos propicia a probabilidade dos micro-organismos de colonizarem outras áreas, se espalhando através das superfícies epiteliais contínuas e contíguas (Palone et al., 2013). Quando se refere aos microbiomas fúngicos usase o termo "micobioma", usado pela primeira vez em 2010 para expressar a 
somatória das palavras "micologia" e "microbioma" (Underhill e lliev, 2014; Ghannoum et al., 2010).

Apesar de serem considerados um componente minor dos microbiomas, os fungos têm sido reconhecidos como detentores de um papel importante nessas comunidades, sendo alvo de vários estudos (Underhill e lliev, 2014). Projetos governamentais como o Human Microbiome Project (HMP) nos Estados Unidos e Metagenomics of Human Intestinal Tract (MetaHit) na Europa têm fornecido dados importantes (Tremaroli e Backehed, 2012) sobre os micobiomas normais de vários locais do corpo humano, entre eles o da cavidade oral. A cavidade oral é o local propício para o crescimento micobiano (Cui et al., 2013), e mesmo saudável pode chegar a apresentar mais de 75 gêneros de fungos diferentes (Ghannoum et al., 2010; Cuil, et al., 2010).

Objetivamente, estudar os micobiomas humanos tem como função descobrir o papel que as populações de fungos desempenham em afetar a saúde. Infelizmente, devido à limitação de métodos, dependentes de cultura em micologia, estudos mais adiantados são restritos à análise de algumas espécies como Candida albicans e fungos dimórficos (Perfect e Casadevall, 2006). O conhecimento das relações entre o trabalho e o adoecer constitui parte integrante da cultura da humanidade, e a saúde oral está inclusa nesse processo de adoecimento do ser humano (Alexander et al., 2013). Historicamente, saúde e meio ambiente sempre estiveram intimamente relacionados (Gouveia, 1999). Contudo somente a partir de 1990 essas relações vêm sendo debatidas de forma mais intensa (Mangini e Silva, 2007). As condições de trabalho geram problemas de saúde de uma forma complexa, onde apenas os serviços especializados nem sempre são capazes de resolvê-los (Vello, 2015). As rápidas e severas mudanças no equilíbrio ambiental determinam direta ou indiretamente muitas das doenças da atualidade (Brauner e Zaro, 2012; Mangini, 2010). Uma dessas mudanças pode ser observada com a chegada da cana-de-açúcar no Triângulo Mineiro.

A cana-de-açúcar (Saccharum officinarum ) possui diversas utilidades, tanto em sua forma in natura como na alimentação animal e humana, e até mesmo de forma industrializada como na fabricação de rapadura, melado, álcool 
e açúcar (Klein 2010; Marafante, 1993). Um subproduto da refinação de açúcar é o melaço, produto escuro e viscoso usado na preparação de xaropes comestíveis e para numerosos produtos industriais. Ele também é usado para a alimentação animal como fertilizantes e até mesmo na adição do tabaco para cachimbo e alguns cigarros (Serra e Araújo, 2011), além de participar na produção de rum (De Ferreira et al., 2012). O cultivo da cana estende-se às regiões tropicais e subtropicais de mais de 80 países, sendo o Brasil seu maior produtor, com estimativa de 642 milhões de toneladas colhidas em 2015/2016 (Conab, 2015). O aumento de interesse por essa atividade agrícola está ligado à utilização do etanol como biocombustível, uma alternativa que gera menos poluição em relação ao uso de combustíveis fósseis como gasolina e diesel.

A safra 2014/15 gerou aproximadamente 28,66 bilhões de litros de etanol, ou seja, 2,53\%, a mais do que os 27,96 bilhões de litros da safra 2013/14. Desse total, 11,80 bilhões de litros foram de etanol anidro e 16,86 bilhões de litros de etanol hidratado (Conab, 2015), o que demonstra a expressividade econômica dessa atividade. De acordo com o levantamento da safra 2013/14 de cana-deaçúcar, elaborado pela Conab (Companhia Nacional de Abastecimento), Minas Gerais foi a segunda maior produtora, em termos de área ocupada por essa cultura, perdendo apenas para São Paulo e superando Goiás.

A área destinada ao plantio de cana em 2015, no território mineiro, foi ampliada em 14,7\% em todo o Estado e a produção foi de 61,35 milhões de toneladas, com alta de $19,80 \%$ (Conab, 2015). Sua rentabilidade poderia ser maior, mas a perda econômica nessa atividade rural, principalmente pelas doenças fúngicas e bacteriana da planta, tem onerado os lucros agrícolas (Embrapa, 2013).

De forma análoga à economia brasileira, a economia de Minas Gerais cresceu com o desenvolvimento de usinas de álcool e aumento significativo da produção comercial, apresentando com isso transformações nas condições de vida da população diretamente ligadas à chegada de migrantes para as safras dessa cultura (Diawara et al., 2015). Os efeitos dessa expansão repercutiram também no quadro de "assoreamento" humano. O mercado de trabalho transformou as relações e tipos de vínculo empregatício, originando profundas 
repercussões sociais tanto na vida cotidiana como no processo saúde - doença (Duarte e Oliveira, 2013). Esse processo de mobilidade espacial humana, apresenta características e consequências que vão além de sua quantificação e, muitas vezes, não é possível sua estimação (Oliveira, 2014).

Os impactos ambientais causados pela cultura da cana são amplamente conhecidos, sendo sua principal causa a sua colheita (Dias, 2012). Até 2002, ela ocorria de modo manual com prática da queima em aproximadamente $60 \%$ das áreas plantadas e empregavam quase 500 mil trabalhadores em todo o país (Conab, 2015). O resíduo gerado dessa prática atingia cerca de 160 milhões de toneladas anuais, sendo 70,2 milhões de toneladas de bagaço e 87,7 milhões de toneladas de palha (Embrapa, 2002). No no fim de 2002, a Lei da Queima da Cana (Lei no 11.241/2002 com vigência no Estado de Sãulo, também usada no Triangulo Mineiro, que trata da queima controlada da cana-de-açúcar para "despalha" e de sua gradual eliminação, teve o objetivo de adequar as áreas de produção ao plano de eliminação de queimadas, sendo que um dos principais objetivos dessa lei foi a introdução do maquinário para colheita, diminuindo o risco à saúde humana (Silva, 2008). Porém, Vilela et al. (2014) contradiz essa expectativa afirmando que a "maratona" dos canaviais herdada do corte manual se revela mais veloz, e essa nova introdução do maquinário talvez, seja mais perigosa para os trabalhadores dos canaviais.

Nos trabalhadores da cana-de-açúcar, o impacto na saúde tem sido medido principalmente em relação ao esforço físico intenso, às atividades repetitivas, intempéries climáticas, utilização maciça de produtos químicos, bem como o meio ambiente relacionado com os efluentes das usinas processadoras de álcool e açúcar (Rocha et al., 2010).Observa-se que apesar da introdução do maquinário e consequente diminuição de trabalhadores contratados, a ressuspensão de partículas durante o plantio e da colheita mecanizada mantémse como a principal forma de disseminação de alergênicos nos campos dessa atividade laboral (Murray e Lopez, 2013; Lim, et al., 2012).

Paralelamente ao plantio da cana-de-açúcar, a produção de frutas no Brasil é significativa, abrangendo uma área total cultivada de 2,2 milhões de hectares distribuídos pelo país e emprega em torno de 5,6 milhões de pessoas, 
correspondendo a 34\% da mão de obra rural. Minas Gerais lidera em primeiro lugar do ranking nacional em relação à produção de abacaxi (Guimarães, 2014) e quarto colocado na produção de laranja, com quase $6 \%$ da produção nacional (Epamig, 2015).

A atividade laboral no Triângulo Mineiro tem como característica predominante o trabalho agrícola nas culturas de abacaxi, com $94 \%$ da produção nacional (Guimarães, 2014), e de laranja, com cerca de 17,48 milhões de caixas produzidas (Fundecitrus, 2016), sendo que o Munícipio de Frutal ocupa o primeiro lugar na produção do Estado nessas culturas (Ministério da Agricultura, 2010). Segundo a revista especializada Campo - Negócio (2015), só no período de plantio do abacaxi há uma demanda de cerca de dez trabalhadores por dia nessa atividade e, em relação à cultura da laranja, o período de colheita pode atingir em torno de 120 trabalhadores/dia, dependendo dos hectares plantados, com contratação de trabalhadores oriundos de diversos locais (Gestão do Campo, 2015).

Em relação à mão de obra empregada no município de Frutal na cultura do abacaxi, a contratação por período temporário é quase insignificante pelo montante do trabalho empregado, sendo que grande parte dos trabalhadores são de convívio familiar (Mendes, 2005) e o índice dessas contratações atingem menos de $10 \%$ do total de mão de obra empregada. Os acidentes de trabalho são muito frequentes nessa atividade laboral, principalmente ferimentos no corpo (olhos, mãos, barriga, pernas, região da virilha) provocados pelas folhas e espinhos do abacaxi (Gonzaga et al., 2014). O contato com as plantações é constante, sem períodos de longo afastamento dos trabalhadores (Guimarães e Matos, 2012; Mendes, 2005), o que propicia a investigação nesse grupo laboral.

$\mathrm{Na}$ cultura de laranja, por sua vez, emprega-se trabalhadores de ambos os sexos com idade entre 18 a 65 anos. A colheita manual apresenta características próprias, utilizando escada de madeira leve e arredondada, sacolas de colheita feitas de lona com capacidade de $20 \mathrm{~kg}$, tesoura ou alicate de colheita (lâminas curtas e pontas arredondadas) e cestos ou caixas plásticas com capacidade de $27 \mathrm{~kg}$ (Costa, 2013). Cada trabalhador pode colher $10 \mathrm{mil}$ frutos/dia. Esses trabalhadores permanecem com os membros superiores 
elevados por longos períodos e um dos acidentes mais comuns são as quedas das escadas (Koller, 1994).

A área de coleta da fruta é dividida em lotes para cada grupo de colhedores e o ganho financeiro é associado, em muitos casos, à produtividade do grupo. Segundo Rodrigues et al. (2010), existem três tipos principais de trabalhadores de laranja: desbrotadeiros, pragueiros e colheitadores. Trabalham por turnos de oito horas diárias, com possibilidade de mais duas horas extras por semana. As atividades são realizadas com a utilização de EPI (Equipamento de Proteção Individual) fornecido pelo empregador (Costa, 2013; Rodrigues et al., 2010).

Em relação à cana-de-açúcar na região do município em questão, somente em 2008 a região recebeu incentivo Federal para expansão do plantio (Campos Filho e Santos, 2008), o que gerou um aumento na extensão da área plantada dessa gramínea. Frutal foi um dos que mais expandiu em extensão o plantio da cana, gerando um aumento de migrantes oriundos principalmente do nordeste brasileiro (Villas-Boas, 2009). Isso acarretou cerca de $27 \%$ de aumento de atendimentos nos ambulatórios, aumento expressivo no atendimento médico - odontológico (Prefeitura Municipal de Frutal, 2010), refletindo também no ambulatório de dermatologia. O processo de crescimento na região impactou nas condições de saúde da região, com um aumento de internações hospitalares por doenças diversas. Devido às subnotificações dos agravos relacionados ao trabalho na cana-de-açúcar, não se pode avaliar o real dano à saúde desses trabalhadores (Villas-Boas, 2009).

$\mathrm{Na}$ clínica geral, as micoses dependem do agente causal, do local da infecção e da predisposição do hospedeiro. Uma das classificações práticas utilizada e baseada na localização da infecção classifica-as como superficiais, cutâneas, subcutâneas e profundas ou sistemicas (Coronado-Castellote e Jiménez-Soriano, 2013).

Em relação à especialidade dermatológica ambulatorial, as infecções fúngicas superficiais e cutâneas são encontradas com frequência, e em sua maioria, seus aspectos clínicos são bastante característicos, facilitando assim o 
diagnóstico (Pires et al., 2014; Aquino, Constante e Bakos, 2007; Brilhante et al., 2000). Muitos fatores interferem na incidência dessas micoses e, entre eles, podemos citar condições bioclimáticas favoráveis ao desenvolvimento dos fungos em vida saprofítica, promiscuidade, sudação e contato prolongado com pequenos animais (Mendes, 2014; Aquino, Constante e Bakos, 2007; Almeida et al., 2004).

Entre as diversas patologias atendidas no ambulatório de dermatologia do Munícipio, observou-se um aumento de lesões do tipo afta em região oral. Essas lesões observadas nos trabalhadores oriundos dos campos de cana-de-açúcar já haviam sido observadas em outras culturas típicas da região, porém, em menor índice. As lesões eram de difícil controle clínico havendo, muitas vezes, a necessidade da realização de biopsia. Em alguns casos, o resultado histopatológico constatou a presença de fungos filamentosos no material analisado, o que despertou interesse do pesquisador sobre o caso, buscando uma investigação mais aprimorada.

Baseando-se na literatura referendada, que relata a grande incidência de fungos nas plantações de cana-de-açúcar e outras culturas associadas a possibilidade de contaminação fúngica humana pelas condições ambientais em que os trabalhadores estão expostos, questionou-se a existência de uma relação entre atividade laboral e contaminação humana em região oral por fungos filamentosos.

\subsection{Relevâncias e Justificativa}

Desde a segunda metade do século $X X$ observa-se que determinadas espécies de fungos têm emergido de uma forma crescente, sendo responsáveis por diversas doenças no ser humano (Jesus, 2013; Abu-Elteen e Hamad, 2012; Fisher et al., 2012). Mesmo com um aumento expressivo de cerca de $200 \%$ nas últimas décadas (Robbins et al., 2011), as micoses não são doenças de notificação compulsória para a Organização Mundial de Saúde e, no Brasil, o diagnóstico é ainda mais desfavorável, especialmente em áreas onde não há um 
médico com qualificação profissional para diagnosticá-las corretamente e tratálas (Nascimento et al., 2014; Lacaz, 2002).

A atividade rural no país sempre foi expressiva, mas as condições de trabalho e de vida sempre foram muito precárias, principalmente nas monoculturas, o que têm sido fonte de desgaste e adoecimento do trabalhador mesmo com a modernização dos campos (Scopinho, 2010).

No agronegócio, os trabalhadores de cana-de-açúcar são um grupo especial de atividade laboral realizada ao ar livre, com a exposição do homem diretamente ligada às condições adversas do meio ambiente, como altas temperaturas; com roupas inadequadas e equipamentos de proteção mínima para o trabalho (Villas-Boas, 2009; Rumin, Navarro e Periot, 2008; Scopinho, Eid e Viana, 2003).

A relação trabalho-condição de vida e saúde geram diversos estudos sobre os danos para a saúde de trabalhadores de diversas áreas. Quando se associa essa relação ambiental e humana à lavoura de cana-de-açúcar (Bittencourt, Ruas e Maia, 2012), além de que, no Brasil, a saúde bucal tem sido negligenciada, não levando em consideração que qualquer problema de origem bucal pode provocar desconforto físico e emocional e prejuízos consideráveis à saúde geral (Santos e Leite, 2012), obtém-se um cenário que pode favorecer a contaminação fúngica filamentosa em mucosa oral nessa atividade laboral.

Em relação aos estudos epidemiológicos, esses mostram a distribuição dos diversos agentes etiológicos causadores de infecções fúngicas superficiais e cutâneas nos Estados de São Paulo, Goiás, Rio Grande do Sul, Santa Catarina, Minas Gerais e Distrito Federal (Barbosa et al., 2014; Ministério da Saúde, 2010).

Porém, as infecções de mucosas oral, por serem menos características, são menos reportadas, desconhecendo-se dados precisos sobre incidência e prevalência destes quadros (Neme, 2004; Brilhante et al., 2000). As poucas pesquisas realizadas em relação às mucosas avaliaram somente a mucosa ocular e nenhuma analisou especificamente quanto à possível influência fúngica 
filamentosa na região orofaringe (Dalfré et al., 2007; Novaes 2007; Scopinho, Eid, Viana, 1999).

Trabalhadores das culturas de abacaxi e laranja já vinham apresentando lesões semelhantes às dos trabalhadores recém-chegados ao município. Com o aumento da migração para a região devido ao plantio da cana-de-açúcar associado à observação empírica de aumento de lesões em região oral, gerouse a necessidade de responder ao questionamento da possível associação da atividade sucroalcooleira com o quadro dermatológico, porque não há nenhum levantamento específico realizado pelos órgãos de saúde até o momento. A comparação de trabalhadores de outras atividades poderia dar uma posição mais fidedigna na busca dessa resposta, devido à falta, na literatura vigente, de uma análise sobre a contaminação fúngica filamentosa em mucosa oral em trabalhadores das culturas de cana-de-açúcar, abacaxi e laranja.

Assim, o presente estudo pretende contribuir para o conhecimento da exposição profissional a fungos filamentosos potencialmente patogênicos à saúde dos trabalhadores dos campos de cana-de-açúcar, comparando-os ao dos campos de laranja e abacaxi, visando facultar dados para uma adequada avaliação do risco e vigilância médica aos trabalhadores. 


\section{REVISÃO BIBLIOGRÁFICA}

\subsection{Cana-de-açúcar}

\section{- Passeando pela história}

A cana-de-açúcar é uma gramínea originária do sudeste da Ásia onde é cultivada desde épocas remotas, sendo considerada uma planta silvestre e ornamental (Ribeiro,1997). Ela é constituída de um sistema radicular (colmos), onde predomina o estoque de sacarose; as folhas estão dispostas ao redor da cana, nos nódulos inter-colmos e também na parte superior da planta, onde se localiza a gema apical (palmito) (Mantelatto, 2005).

Brandes, em 1956, atribuiu à Nova Guiné o local original da cana-deaçúcar, o que é mais aceito atualmente (Irvine, 1993; Barnes, 1964).

Tomando como ponto de referência a Nova Guiné, a cana teve três principais rotas de disseminação através dos tempos: por volta do ano 8000 a.C., a cana-de-açúcar foi levada para as Ilhas Solomon, Nova Caledônia, e Novas Hébridas; dois mil anos depois, aproximadamente, no ano 6000 a.C., seguiu em direção ao leste a caminho das Filipinas, Indonésia, Bornéu, Java, Malásia, Burma e para a Índia; e, finalmente, entre os anos 550 e 1100 d.C., seguiu o caminho oeste em direção a Fiji, e de Fiji para Samoa, Taiti e Havaí, assim como para outras regiões da Oceania (Innes (Review Blackburn,1985)).

A mais antiga menção escrita sobre a cana-de-açúcar foi encontrada em arquivos indianos datados de 1400-1000 a.C. (Irvine, 1993). Ao ser levada para a Índia foi considerada uma planta dos deuses, como descrito no "Atharvaveda", o livro dos Vedas (escritura sagrada do povo indiano), através da descrição do deus Kamadeva. Esse deus é representado como um jovem bonito e alado que carrega um arco feito de cana-de-açúcar e com uma corda feita de mel de abelhas. Já nas Sagradas Escrituras cristãs, a cana-de-açúcar é reportada para 20.000 a.C., e foi citada em Isaias 42:3: "não esmagará a cana quebrada, nem apagará a torcida que fumega: em verdade, promulgará o direito..." (Cesnik e Miocque, 2004), e nessa época era usada como alimento e remédio. Era 
totalmente desconhecida no Ocidente e foi difundida através de alguns generais como Alexandre, o Grande, em 327 a.C. e mais tarde, no século XI, durante as Cruzadas, onde recebeu a importância como previsão alimentar nos grandes deslocamentos militares, sendo plantada nas trilhas de combates. Já os árabes introduziram seu cultivo no Egito no século X, pelo Mar Mediterrâneo, em Chipre, na Sicília e na Espanha (Machado, 2003).

Até o ano 500 a.C., os persas guardavam o segredo da fabricação do açúcar que era comercializado com os romanos, um açúcar de coloração escura, com tons de preto e marrom. Atribuiu-se aos egípcios o desenvolvimento do processo de clarificação do caldo da cana e um açúcar de alta qualidade para a época, mas que manteve segredo por algum tempo (Delgado e Cesar, 1977).

Nas Américas, a chegada da cana-de-açúcar ocorreu somente através da segunda expedição de Cristóvão Colombo, em 1493, que levou mudas de canade-açúcar junto às suas provisões para serem plantadas em novas terras e servirem de suprimentos às novas expedições (Cesnik e Miocque, 2004).

A cana foi descrita cientificamente por Linneu em 1753 como Saccharum officinarum e Saccharum spicatum. Essa classificação sofreu inúmeras modificações, e a mais aceita atualmente é a de Jeswiet, sendo essa: gênero: Saccharum; espécies: S. barberi, Jeswiet; S. edule, Hask; S. officinarum; S. robustum, Jeswiet; S. sinensis, (Roxb) Jeswiet e S. spontaneum (Viera, 2002).

Em 1887, em Java, Soltweld realizou o primeiro cruzamento do mundo entre duas espécies de cana-de-açúcar: Glagah e Loethers, obtendo somente toletes férteis da espécie Glagah, iniciando, assim, a viabilidade do melhoramento genético da cana-de-açúcar por intermédio de cruzamentos controlados (Cesnik, 2004). Dois anos após, Harrison e Bowell obtiveram seedlings (mudas) de sementes originárias de cruzamentos, dando origem aos primeiros programas de melhoramento genético (Gallo et al., 1988). 


\section{- No Brasil}

As primeiras mudas que chegaram ao Brasil foram trazidas da llha da Madeira por Martim Afonso de Souza, responsável pela instalação do primeiro engenho denominado de São Jorge, na vila de São Vicente - SP, no ano de 1533 (Castro, Klige, 2001). Muitos outros engenhos se proliferaram pela costa brasileira e região nordeste, principalmente nos litorais pernambucano e baiano, concentrando-se a maior parte da produção açucareira da colônia. A exploração canavieira era, no início, exclusivamente sobre a espécie $S$. officinarum, que apresentava grande teor de açúcar, perdurando por mais de um século (Machado, 2003).

A partir do litoral, a cana caminhou em direção ao agreste, chegando às regiões mais úmidas do sertão nordestino, e foi através dela que ocorreu a sustentação do processo de colonização do Brasil, tendo sido a causa de sua prosperidade nos dois primeiros séculos (Cotrim, 2005; Botelho e Reis, 1998). $O$ apoio do governo português deu ênfase ao plantio da cana-de-açúcar por diversas razões, entre elas, podemos destacar a dominação portuguesa das técnicas de plantio de cana, pois já haviam exercido tal atividade nas llhas Atlânticas de Madeira e Açores, também colônias de Portugal. Outro fator determinante foi que o açúcar era um produto de grande aceitação na Europa, tido como ouro branco e oferecia grande lucro. Por fim, também deve-se destacar o clima e o solo brasileiro como dois fatores naturais que favoreciam esse tipo de atividade. Isso tudo estava associado à necessidade de cumprimento do Tratado de Tordesilhas, com a ocupação da terra (Fausto, 2006).

A cana-de-açúcar teve influência direta nas orientações socioeconômicas da época: para melhor organizar a colônia, o rei dividiu o Brasil em Capitanias Hereditárias; o território foi dividido em faixas de terras que foram doadas a donatários que podiam explorar os recursos da terra, mas ficavam encarregados de povoar, proteger e estabelecer o cultivo da cana-de-açúcar. As plantações ocorriam no sistema de plantation, ou seja, eram grandes fazendas produtoras de um único produto, utilizando mão de obra escrava e visando o comércio 
exterior (Fausto, 2006). Com a Abolição da Escravatura, a agroindústria açucareira precisou remanejar recursos para procurar mão de obra, modernizar os equipamentos e ampliar as usinas, passando a centrifugar sua própria matéria-prima, técnica essa utilizada em Cuba e na Antilhas desde 1870 (de Oliveira, 2012).

Após a Segunda Guerra Mundial, o Brasil passou a investir maciçamente nessa produção devido à destruição dos canaviais europeus, revigorando assim a inserção dessa produção no mercado internacional (Machado, 2003).

No fim de 1973, o preço do barril de petróleo atingiu 2,94 dólares, dificultando a economia no terceiro mundo, agravada com a guerra do "Yom Kippur - o Dia do Perdão". A crise econômica sofrida pelos países ocidentais com a queda do petróleo exigiu da produção mundial um investimento em outras fontes de energia, fator decisivo para a economia global, o que propiciou ao Brasil o investimento na tecnologia do álcool (Barros, 2007).

Com o aumento dos investimentos, a agroindústria canavieira passou por um processo de modernização e diversificação, expandindo-se de uma forma intensa na década de 70 para além das regiões tradicionalmente produtoras. Essa expansão foi apoiada por investimentos internacionais e políticas nacionais que favoreceram o setor (Arbex, 2004).

No final do século $X X$, com o desenvolvimento da indústria do álcool, o plantio canavieiro se disseminou por várias regiões do país, com predomínio na região sudeste. O Brasil se tornou líder nas tecnologias de produção do etanol extraído da cana-de-açúcar no final de 2007 , sendo responsável por $45 \%$ da produção mundial feita em mais de 400 usinas e destilarias naquela época (Gonçalves, 2009).

No início do século XXI, mais precisamente entre os anos de 2001 e 2005, a produção canavieira no Brasil cresceu cerca de $21 \%$, impulsionada por fatores como a demanda do mercado externo por açúcar e pelo crescente consumo interno de álcool como combustível de veículos automotores (Alves, 2007).

A cana-de-açúcar apresenta várias doenças causadas por fungos: 
Carvão - Ustilago scitaminea

Ferrugem - Puccinia melanocephala e Puccinia kuehnii

Podridão-Vermelha - Fusarium moniliforme e Colletotrichum falcatum

Pokkah Boeng - Fusarium moniliforme

Mancha Parda - Cercospora longipes

Mancha Anelar - Leptosphaeria sacchari

Mancha Ocular - Helminthosporium sacchari

Podridão-Abacaxi - Ceratocystis paradoxa

O que compromete a produtividade da gramínea (Embrapa, 2009).

O gênero Fusarium tem uma importância relevante no agronegócio mundial, pois agride várias culturas, inclusive no Brasil (Embrapa, 2005). Na cana-de-açúcar pode ocorrer uma doença denominada de fusariose, cujo agente principal é o Fusarium moniliforme com variação subglutinans, formando uma espécie anamorfa, Fusarium subglutinans. Caracteriza-se por ser uma doença sistêmica que pode provocar o aparecimento de diversos sintomas durante 0 desenvolvimento da planta e está presente em todas as regiões produtoras (Canaoeste, 2012). O Fusarium moniliforme é um parasita obrigatório que infecta da goma até a planta adulta. Os sintomas da fusariose são variáveis e dependem das condições ambientais, do nível de resistência da variedade e do estágio de desenvolvimento da cultura (Verzignassi, 2009). A fusariose apresenta um fenômeno denominado Pokkah-boeng, ou deformação do topo da cana-deaçúcar, onde as folhas apresentam áreas cloróticas e enrugadas, tornando-se "torcidas" (Vishwakarma et al., 2013). Esse fenômeno é mais frequente em condições de alta temperatura e umidade, quando a planta está em pleno desenvolvimento. Área colhida sem queima, em solos de boa fertilidade em regiões quentes podem favorecer 0 aparecimento de Pokkah-boeng, principalmente pela grande capacidade de produzir esporos que o Fusarium $s p$ apresenta (Rumora et al., 2002). 


\section{- Cana-de-açúcar no Triângulo Mineiro}

O Triângulo Mineiro está inserido no bioma cerrado, que são formações que ocorrem no clima tropical e subtropical. Com uma vegetação variada, frutas e uma produção pecuária relevante no contexto nacional, o Triângulo Mineiro é uma das regiões mais ricas do estado com a economia voltada ao agronegócio. Essa região apresenta um extrato de gramíneas, havendo interrupções por árvores e arbustos, constituindo uma área com boas condições para a prática da agropecuária (Roslen, 2007).

As principais indústrias instaladas nesse local relacionam-se aos setores de processamento de alimentos, madeira, açúcar, álcool, fumo e fertilizantes. Nos últimos anos, o Triângulo Mineiro foi a região que mais recebeu investimentos e gerou empregos (Minas Gerais, 2010).

Por ser uma região estratégica do ponto de vista de escoamento de produção, iniciou-se em 2008 a implantação e a expansão, em Minas Gerais, de cinquenta projetos de usinas produtoras de açúcar e álcool. Os investimentos alcançaram a ordem de 3,7 bilhões de dólares e a estimativa de crescimento da moagem de cana é de $250 \%$ até 2017 , com a criação de 56 mil empregos, colocando o Estado de Minas no terceiro lugar como produtor de cana-de-açúcar e de álcool, depois de São Paulo e Paraná, e de açúcar, depois de São Paulo e Alagoas (Secretaria de Minas e Energia-MG, 2010).

Em meados de 2009, o Triângulo Mineiro concentrava 68\% da produção de cana-de-açúcar, $79 \%$ da produção de açúcar e $61 \%$ do álcool produzido no Estado, devido à implantação do Programa de Aceleração do Crescimento (PAC), incentivo esse vindo do governo federal, que compreende ações estaduais e empreendimentos de abrangência regional nos eixos denominados de infraestrutura Logística, Energética, Social e Urbana, inclusive obras de saneamento e habitação (Villas Boas, 2009).

Em 2010, aproximadamente 587 milhões de reais de investimentos foram feitos na região para a produção etanol nos municípios de Delta, Uberaba, Uberlândia e Frutal. Juntamente com o Estado do Mato Grosso, o Triângulo Mineiro recebeu e instalou 67 novas usinas de álcool e mais 20 foram 
programadas para serem construídas até 2015, um investimento estimado em 15 bilhões de reais. Em um período de 19 anos, a safra de cana do Estado de Minas Gerais cresceu em torno de 400\% (Única, 2009).

O crescimento da cultura da cana fez crescer também a migração de trabalhadores do nordeste do país para as regiões produtoras do sudeste e centro-oeste (Minas Gerais, 2009).

\section{- Cana-de-açúcar, saúde humana e os fungos.}

Se voltarmos na história, pesquisadores como Andreae (1991) atribuiu como uma das causas do desaparecimento dos grandes répteis no período Cretáceo a mudança do clima causada pelas queimadas e pelas fuligens produzidas por elas, o que enfatiza a necessidade de se ter uma visão mais humanista dessa atividade laboral.

Desde o começo do século XXI já era verificada a presença de bactérias e esporos de fungos, incluindo os gêneros Alternaria, Cladosporium, Fusariella e Curvularia em fumaça proveniente da queima de biomassa (Ribeiro, 2008;Mims e Mims III, 2004).

Há uma tendência de diminuição dos impactos físicos nos trabalhadores da cana-de-açúcar com a mecanização, mas o índice de poluição e da biomassa liberada é muito alta devido à poeira do tráfego de veículos e colheitadeiras na cultura. Além disso, há uma associação térmica com temperaturas elevadas, proporcionando outros danos físicos (Ripoli, 2005). Com a ressuspensão de partículas no meio ambiente, há um favorecimento à disseminação de esporos fúngicos e micro-organismos. Ao encontrar um substrato propício ao seu desenvolvimento, esses micro-organismos proporcionam a produção de substâncias com grande potencial para uso farmacológico, na agricultura e em biotecnologia, mas os micro-organismos em associações com as plantas produzem metabólitos que podem ser de extrema ação patogênica aos seres humanos, podendo apresentar efeitos mutagênicos, estrogênicos e carcinogênicos, havendo consequências futuras (Schimit,1997). 
A produtividade possui correlação imediata com as condições de trabalho e os processos de adoecimento do trabalhador, e para cada etapa da produção de derivados da cana (Figura 1) existem patologias associadas, o que determina um campo exploratório bastante expressivo. Como as interações entre microorganismos e plantas são bastante conhecidas, elas constituem um campo de estudo bastante prolífico devido à exposição constante dos trabalhadores dessa atividade laboral (Faria, 1987).

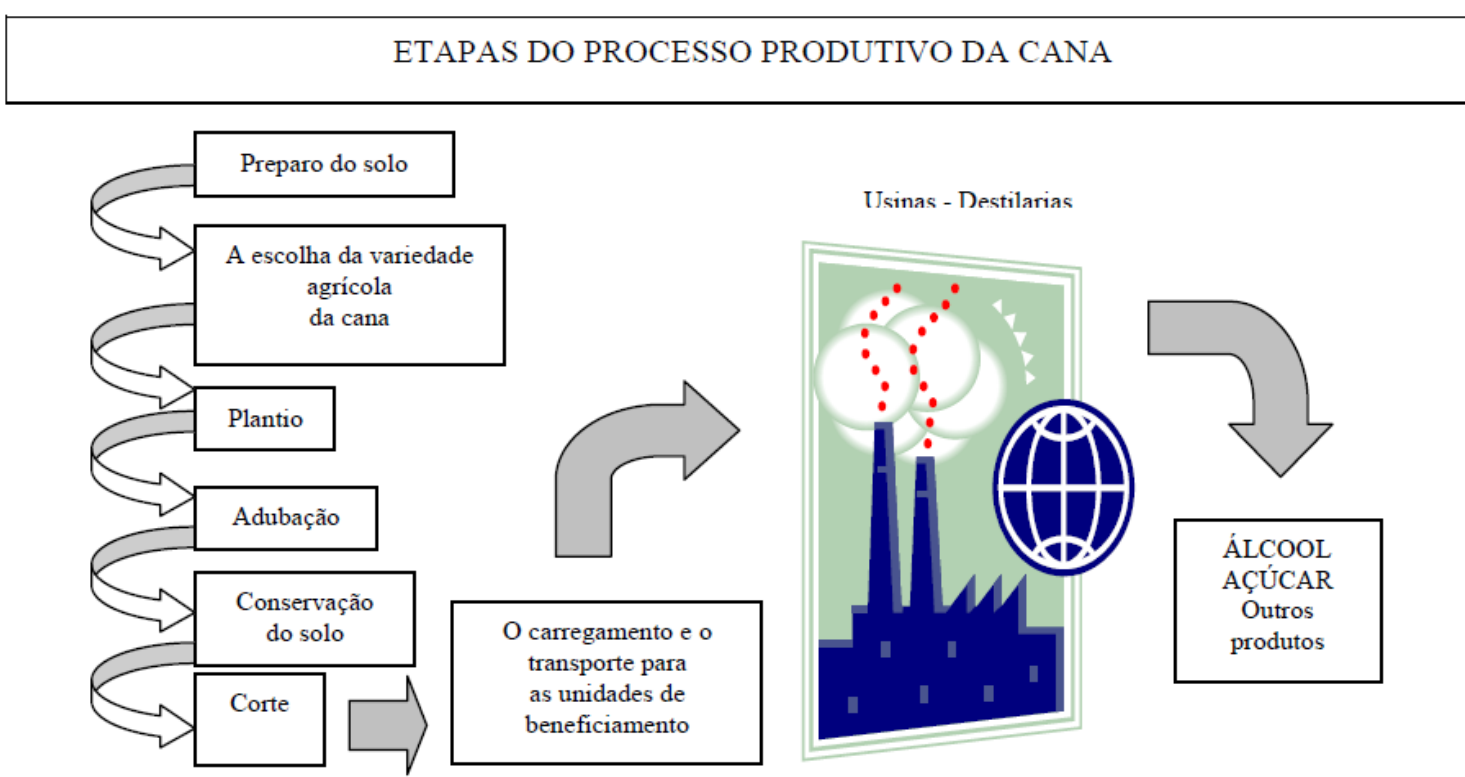

FONTE: Modificado da Plataforma BNDES. Impactos da indústria canavieira no Brasil. Versão Preliminar. - Modificada por Villas-Boas, 2009.

Figura 1 - Etapas do processo produtivo da cana no setor sucroalcooleiro.

Existe uma boa documentação sobre os efeitos adversos para os sistemas respiratório e cardiovascular provocados pela queima da biomassa (Arbex, 2001) e alguns fungos, como do gênero Alternaria, que são descritos como responsáveis por causarem reações alérgicas e crises de asma brônquica. (Ribeiro, 2008 e Mims e Mims III,2004 ). As alergias respiratórias e cutâneas têm em comum a mesma forma fisiopatológica, assim, as formas fúngicas causadoras de problemas respiratórios também podem acarretar problemas cutâneo-mucosa (Godinho et al., 2003). Esses patógenos podem ser disseminados através da fumaça e da poeira de partículas, aumentando, assim, o alcance da ação dos efeitos adversos deles para além dos campos de cana- 
de-açúcar, o que pode gerar a contaminação de pessoas que não possuem ligação direta com essa cultura (Arbex, 2001).

Sendo assim, a interação do trabalhador com o ambiente em que exerce suas atividades, bem como o contato direto com as gramíneas, podem trazer riscos à saúde, levando em consideração que as infecções fúngicas que ocorrem no homem são adquiridas essencialmente através do ambiente em que está exposto (Villas Boas, 2004).

\subsection{Plantio da laranja}

A trajetória da laranja pelo mundo é conhecida apenas de uma forma aproximada. Os cítricos teriam surgido no leste asiático, onde a primeira descrição aparece há 2000 a.C. na literatura chinesa, tendo como nome científico Citrus sinensis. Seu registro foi feito pelo imperador Ta Yu, (Fernades, 2010), e teria sido levada da Ásia para o norte da África e de lá, para o sul da Europa, onde teria chegado na Idade Média. Da Europa foi trazida para as Américas na época dos descobrimentos, por volta de 1500 (CitrusBr, 2015).

Historicamente, a laranja foi trazida através do oceano atlântico em 1493 por Cristóvão Colombo. Ele transportou mudas de laranja e limão das Ilhas Canárias espanholas para o Haiti e República Dominicana. As mudas chegaram ao Panamá através dos espanhóis em 1516 e no México dois anos depois. $\mathrm{Na}$ mesma época, os portugueses trouxeram as primeiras mudas de laranjas doces para o Brasil (CitrusBr, 2015; Afeira, 2015).

A decadência do cultivo do café devido às geadas de 1918 e 1929 fez com que o Estado de São Paulo abrisse espaço para outras culturas, principalmente para o cultivo de citros, dando ênfase na laranja (Fernades, 2010). É um negócio significativo para a economia brasileira e uma importante parte da economia de vários países e regiões europeias, sendo o Brasil o primeiro produtor mundial (Embrapa, 2011).

O cultivo se dá no período chuvoso típico da região ou em qualquer época com auxílio da irrigação, escolhendo-se dias nublados sem ventos e com 
temperatura amena. Entre o plantio e a primeira florada significativa leva-se em torno de três anos, com produção crescente nos anos subsequentes. Considerando-se o início de produção, aos quatro anos de vida colhe-se 100 frutos por laranjeira/ano, 150 frutos ( $5^{\circ}$ ano), 200 frutos ( $6^{\circ}$ ano), 250 frutos ( $7^{\circ}$ ano), 300 frutos ( $8^{\circ}$ ano). Pés safreiros (10 anos) podem produzir 350 frutos (Bahia), 420 frutos (Baianinha) e 580 frutos (Pera) (Embrapa, 2011).

O clima favorável ao seu plantio está na faixa de temperatura para vegetação entre $22^{\circ} \mathrm{C}$ e $33^{\circ} \mathrm{C}$ (nunca acima de $36^{\circ} \mathrm{C}$ e nunca abaixo de $12^{\circ} \mathrm{C}$ ) com média anual em torno de $25^{\circ} \mathrm{C}$; sob altas temperaturas a laranjeira emite, ao longo do ano, vários surtos vegetativos seguidos de fluxos florais que possibilitam maturação de frutos em várias épocas. O ideal anual de chuvas está em $1.200 \mathrm{~mm}$ bem distribuídos ao longo do ano; déficit hídrico deve ser corrigido com irrigação artificial. Devido a estas características a plantação de laranja no município de Frutal é tão significativa. (Epamig, 2007)

Em 2014, a produção no Triângulo Mineiro destinada à indústria de suco atingiu cerca de 8,4 milhões de caixas de $40,8 \mathrm{~kg}$, e a produção destinada à mesa foi estimada em 1,5 milhões de caixas de $40,8 \mathrm{~kg}$, totalizando uma produção comercial de aproximadamente 9,9 milhões de caixas de laranja de 40,8 kg (Conab, 2015).

A colheita se inicia em junho com pico em setembro/outubro, porém, até dezembro ocorre no município a "safrinha", segunda grande produção do ano. Assim, a colheita se dá no período de junho a dezembro com alguns pomares tendo a colheita até janeiro, dependendo da idade dos pés (Conab, 2013).

No Estado de Minas Gerais observa-se que os meses de maior colheita são setembro, outubro e novembro, totalizando $54 \%$ da colheita da atual safra (Conab, 2013).

Dentre as doenças das plantas cítricas, a verrugose é a mais frequente tanto em sementeiras e viveiros como em pomares, afetando somente frutos de laranjas doces. A doença pode ser causada pelos fungos Sphaceloma fawcetii; S. fawcetii var. scabiosa, e pelo S. australis. Ela aparece nas sementeiras e viveiros, afetando os principais porta-enxertos utilizados na citricultura. Os 
sintomas iniciais nas folhas ainda transparentes são pequenas manchas pontuais brilhantes e aquosas (Embrapa, 2003).

Outra importante doença da cultura da laranja é a gomose de Phytophthora, causada pelos fungos $P$. parasitica e $P$. citrophthora. Em plantas adultas os sintomas incluem: exsudação de goma, escurecimento dos tecidos localizados abaixo da casca. Os frutos mais próximos ao solo podem ser contaminados apresentando podridão seca de cloração marrom-parda que apresentam forte cheiro acre (Embrapa, 2003).

\subsection{Plantio do Abacaxi}

O abacaxi é uma planta de clima tropical, monocotiledônea, herbácea e perene da família Bromeliácea, com caule (talo) curto e grosso, ao redor do qual crescem folhas estreitas, compridas e resistentes, quase sempre margeadas por espinhos e dispostas em rosetas. A planta adulta, das variedades comerciais, tem de 1 a 1,20m de altura e 1 a 1,5m de diâmetro. No caule insere-se o pedúnculo que sustenta a inflorescência e depois o fruto. Cada planta produz um único fruto saboroso e de aroma intenso (Embrapa, 2005).

De acordo com Sampaio (1914), a palavra "abacaxi" é provavelmente oriunda de "ibacaxi", que significa fruto cheiroso, da língua Guarani. Segundo a maioria dos naturalistas e historiadores, o abacaxi é originário da América tropical e subtropical (Medina et al., 1978), na região das bacias dos rios Paraná e Paraguai (Bertoni, 1919). Foi levado pelas tribos tupis-guaranis para a América Central e região do Caribe (Bertoni, 1919). Após o descobrimento da América, foi levado para a Europa, Ásia e África e se disseminou pelos vários países rapidamente (Ctenas e Quast, 2000).

Historicamente, em 4 de novembro de 1493, ocorreu o primeiro encontro entre os europeus e o abacaxi quando Cristóvão Colombo, em sua segunda viagem para a região do Caribe, ancorou em Guadalupe, nas Pequenas Antilhas, conhecendo os frutos de abacaxi (Simão, 1998). 
O Brasil é o principal produtor mundial da fruta do abacaxi, sendo responsável por 53\% (IBGE, 2011) da produção mundial, sendo o Estado de Minas Gerais o que apresenta maior destaque, principalmente no Triângulo Mineiro. Do total de 7.203 hectares plantados em Minas Gerais, 6.492 hectares estão naquela região (Guimarães e Matos, 2012). A produção somou 206,2 milhões de frutos contra os 222,28 milhões dos demais estados em 2010 (IBGE, 2010). O município de Frutal conta com dois ciclos num período de 12 meses nos campos de abacaxi, com sua colheita nos meses de junho a dezembro (Embrapa, 2005).

A pesquisa de desenvolvimento de maquinário para plantio, colheita e pulverização tem sido desenvolvido por um produtor da região (Figura 2), no intuito de melhorar a produção que se encontra em declínio devido à fusariose do abacaxi, responsável por grandes prejuízos causados aos lavradores de todos os estados brasileiros onde se cultiva essa fruta (Ventura et al., 1993).

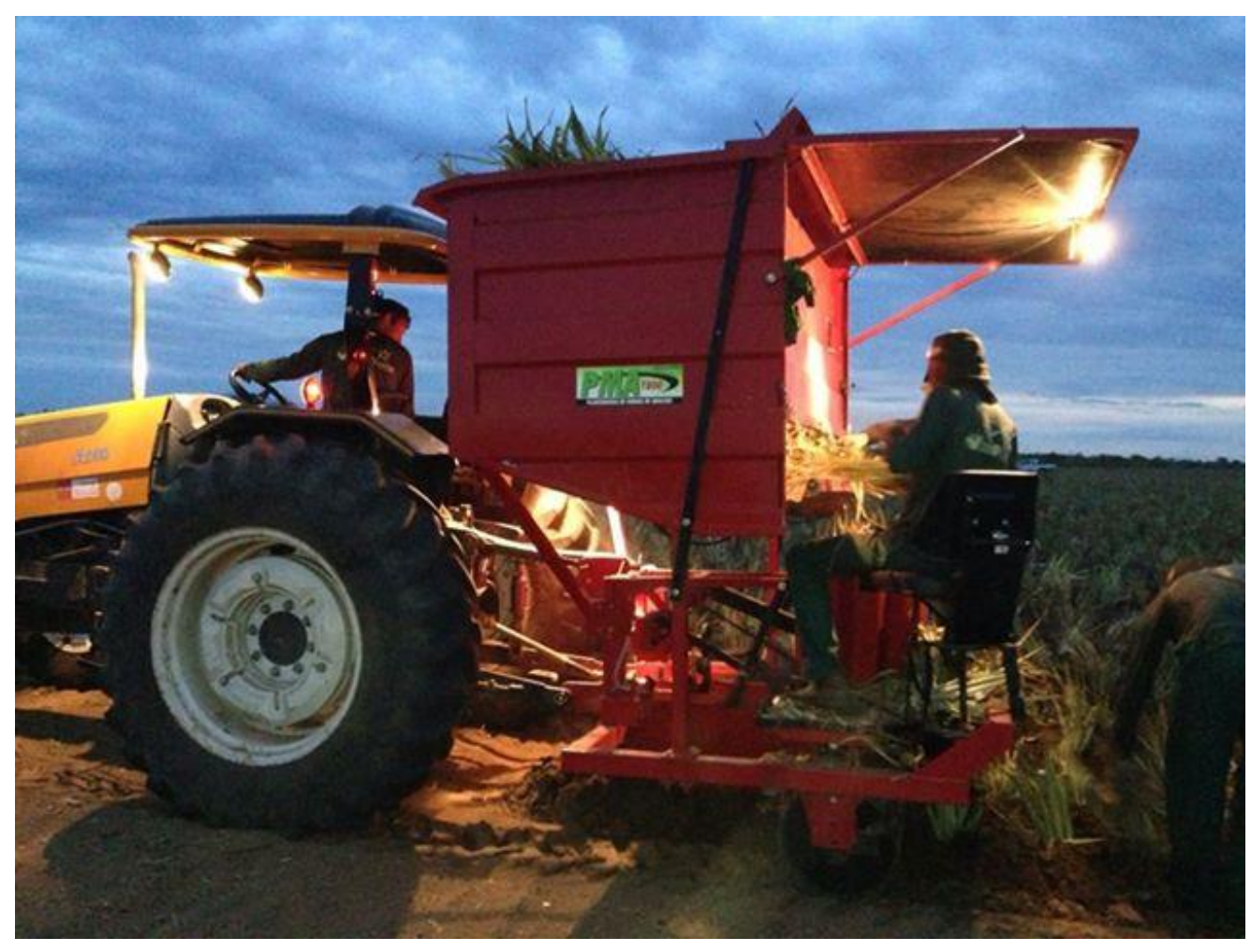

Figura 2 - Plantadeira PMA 1800 - Wagner Guidi-2014.

A fusariose é considerada a principal doença da cultura do abacaxi no Brasil, sendo considerada como a doença de maior importância econômica, com 
uma estimativa de perdas situada em torno de $30 \%$ para o caso de frutos e cerca de $20 \%$ para mudas. No abacaxi, a disseminação da fusariose se dá através de mudas infectadas, correntes de ar e chuvas, o que dificulta seu controle. É causada pelo Fusarium subglutinans e, atualmente, a doença ocorre praticamente em todas as regiões produtoras do país, com predomínio nos dois principais cultivos - pérola e Smooth cayenne - por serem muito suscetíveis à doença (Kimati, 2005). A podridão de fusarium passa então a ter expressão em saúde pública pela possibilidade de contágio dos trabalhadores presentes nessa cultura (Tokeshi, 1997).

\subsection{Os fungos}

A palavra portuguesa fungo deriva do termo latino fungus, que significa cogumelo, usado nos escritos de Horácio e Plínio, o Velho. Mas buscando na história, fungus é derivado do grego sphongos ("esponja"), que se refere às estruturas e morfologia macroscópicas dos cogumelos e bolores (Simpson, 1979).

Os fungos exercem uma importância fundamental na vida diária da população, sendo introduzidos de uma forma indireta na vida humana através das histórias infantis, como no clássico livro "Alice no País das Maravilhas", escrito por Lewis Carroll em 1865 (Moraes, 2012), em jogos como Super Mario Bros, e no filme Fantasia da Disney de 1940, que descreve o fungo Amanita muscaria.

Estima-se que cerca de um milhão e meio de espécies de fungos existam no mundo, com apenas sessenta e nove mil espécies descritas dos mais variados tamanhos. Apresentam uma capacidade em utilizar substratos muito diferentes e naturais, como a água, solo e vegetais, além dos industrializados pelo homem, incluindo tecidos, couro e produtos derivados do petróleo como combustíveis e lubrificantes (Alexopoulous et al., 1996).

Com a introdução dos métodos moleculares de análise filogenética, os fungos deixaram o reino Plantae por suas características próprias, sendo criado 
um reino exclusivo para eles (Bruns, 2006; Bacon e White Jr., 2000) - o reino Fungi. É grupo de organismos eucariotas, distribuídos amplamente pelos ecossistemas existentes, quer de uma maneira saprófita, comensal ou parasita, e se apresentam com formas e tamanhos variados. Esses organismos são aclorofilados e obtêm alimento através de absorção com acúmulo de glicogênio (Schlegel, 1993).

Para que fosse criado esse novo reino, os taxonomistas consideravam que algumas espécies crescem como leveduras unicelulares, que se reproduzem por gemulação ou por fissão binária e que os fungos dimórficos podem alternar entre uma fase de levedura e uma fase com hifas, em função das condições ambientais (Ainsworth, 1976), além de que a sua parede celular é composta por glicanos e quitina, sendo que os glicanos são também encontrados em plantas e a quitina no exosqueleto dos artrópodes (Bowman, 2006). Os fungos são os únicos organismos que combinam estas duas moléculas estruturais na sua parede celular (Hanson, 2008).

A reprodução efetua-se por germinação de esporos. Os esporos maduros são liberados dos aparelhos esporíferos e disseminados. Um esporo germina e emite um filamento, ou hifa, que cresce, alonga-se e ramifica-se para dar um novo micélio. Os esporos assexuados nascem da amputação de pequenos fragmentos citoplasmáticos uni ou multinucleados que se separam na extremidade das hifas (Figura 3) (Guerra et al., 2012). Na reprodução sexuada, o zigoto ou uma célula vegetativa passa por uma divisão meiótica, seguida de uma ou várias divisões mitóticas, que permitem a formação de esporos sexuados haplóides (Scriban, 1985). 


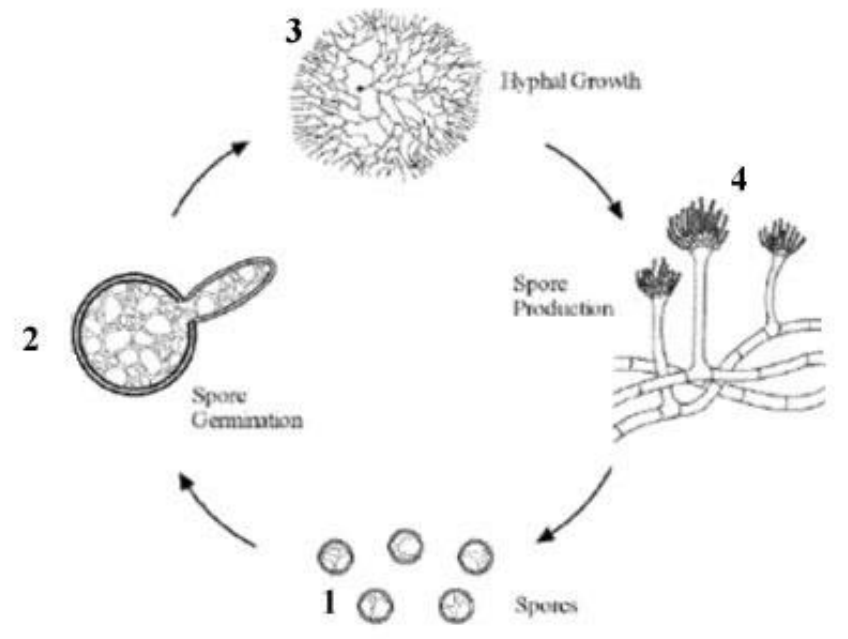

Fonte: Environmental Contrating Restoration (2012).

Nota: Legenda:

1: Esporos (conídeos) - estruturas microscópicas que podem estar dispersas no ar;

2: Germinação do esporo - crescimento de filamentos que formarão as hifas;

3: Micélio - conjunto de hifas que compõem uma massa visível macroscopicamente; e

4: Produção de novos esporos - formação dos conídeos (estruturas de reprodução).

Figura 3 - Mostra esquematicamente o ciclo de reprodução assexuada dos fungos filamentosos (Guerra et al., 2012).

O reino Fungi inclui cinco filos: Chytridiomycota, Zygomycota, Ascomycota, Basidiomycota e Deuteromycota (Freitas, 2000).

O filo Zygomycota integra os fungos saprófitas do solo e parasitas dos mamíferos e plantas. As hifas são cenocíticas; a sua reprodução assexuada fazse por aplanósporos (transportados pelo vento); a reprodução sexuada, quando conhecida, faz-se normalmente por fusão de isogametângios, da qual resulta um zigosporângio contendo um zigósporo (Freitas, 2000).

Já o filo Ascomycota, integra fungos saprófitas, simbiontes e parasitas do Homem, dos animais e plantas, que pode ser unicelular, mas na maioria dos casos é filamentoso e septado. Os septos podem ser fechados por elementos especiais, denominados corpos de Woronin. Sua reprodução é assexuada por conídios e sexuada através dos ascósporos produzidos em ascos, estruturas semelhantes a sacos (Murray, Rosenthal e Pfaller, 2006; Freitas, 2000). 
Os Basidiomycota, constituída por fungos saprófita, simbiontes e parasitas, cujo soma pode ser unicelular ou, como sucede na maioria dos casos, formado por micélio septado. Neste caso, os septos têm a forma especial e característica de barril. Podem também ter estrutura leveduriforme. A sua reprodução sexuada faz-se por basidiósporos, implantados exteriormente em basídios, cujas formas e tipos são importantes em taxonomia (Murray, Rosenthal e Pfaller, 2005; Freitas, 2000).

Quando se refere ao filo Deuteromycota, que inclui os fungos que podem ser saprófita, simbiontes ou parasitas. Seu soma pode ser unicelular ou filamentosa septado e os poros septais podem ser fechados por corpos de Woronin. A única reprodução conhecida, a assexuada e faz-se através de conídios provenientes de diferentes células conidiogéneas. Tanto estas como o tipo de conídios são dois elementos decisivos no posicionamento taxonômico deste filo (Murray, Rosenthal e Pfaller, 2005; Freitas, 2000).

Já o Chytridiomycota é uma divisão onde se encontram organismos com esporos móveis, sem importância clínica devido ao fato de serem parasitas de algas, porém, as evidências que comprovam serem espécies fúngicas devemse à parede celular, enzimas e rotas metabólicas (Murray, Rosenthal e Pfaller, 2005; Freitas, 2000).

Alguns historiadores consideram que, no período pré-histórico, os fungos comestíveis e venenosos, incluindo os alucinogênicos, já eram conhecidos, mas os primeiros relatos sobre os fungos são datados na Grécia cerca de 3.500 anos a.C. (Klyve e Oakley, 1989).

Por muitos séculos na época dos Faraós, os cogumelos eram utilizados como alimento apenas pela "divindade maior" - Faraós - e como veneno pelos sábios e pelos bruxos (Becker, 1997).

Somente nos séculos XVI e XVII o teor místico dos fungos deu lugar aos achados científicos. Foi o alemão Johann Jakob Dillenius (1684-1747) que catalogou 160 espécies de fungos em 1718, em sua obra Catalogus Plantarum circa Gissam sponte nascentium. Mas nos trabalhos de Taylor (1996) que a descrição sobre o registro fóssil de fungos e líquens tomaram vulto com o relato 
de hifas filamentosas intimamente associadas a cianobactérias ou algas; essas estruturas foram preservadas em fosforita marinha na formação Doushantuo (entre 551 e 635 milhões de anos) em Weng'an, sul da China. Todos os fósseis de Doushantuo são aquáticos, microscópicos e conservados com grandes detalhes. Esses fósseis indicam que os fungos desenvolveram parcerias simbióticas com fotoautótrofos antes da evolução de plantas vasculares (Taylor, 1996).

Antônio Micheli, em 1729, fez a primeira descrição compreensiva sobre um fungo na sua obra intitulada Plantarum genera. Christian Hendrik Persoon (17551837) publica Icones pictae specierum rariorum fungorum in synopsi methodica descriptarum em 1803, determinando uma nova visão e perspectivas para a micologia. Em 1835, Bassini relacionou pela primeira vez os fungos como causadores de doenças cutâneas, chamadas de muscardines e, dois anos após, em 1837, Joseph Henri Léveillé (1796-1870) publica Sur Le hymenium des champignons, definindo basídios e cistídios (Tortora et al., 2002).

Apesar de todos os relatos, Elias Magnus Fries (1794-1878) é considerado o pai da micologia moderna, descrevendo mais de três mil formas de fungos com detalhes de sua reprodução e colocações em diversos ambientes. Fries publicou três volumes de sua obra intitulada System Mycologicum, ponto de partida para muitos grupos de fungos (Oliveira, 2014).

O ciclo vital desses organismos é atribuído aos irmãos franceses Charles Tulasne (1818-1884) e Louis René Tulasne (1815-1885), que realizaram desenhos ilustrativos de estruturas microscópicas dos fungos, abrindo condições para melhor esclarecimento desses ciclos (Hibbet et al., 1997).

Uma grande obra sobre os Ascomycetes foi realizada por Giacomo Bresadola (1847-1929), que publicou extensos trabalhos sobre o filo, e sua exatidão das descrições é mantida até os dias de hoje com acréscimos sem, no entanto, ter sido modificado nenhum dos seus escritos (Denison e Carrol, 1966).

Nos séculos XVIII e XIX houve um aumento, por toda Europa, de sociedades iniciadas por amadores da micologia, cujas coleções foram base para estudos científicos acerca dos fungos. A sociedade Micológica da França foi 
fundada em 1884, com grande acervo de literatura especializada, sendo um marco importante para a micologia mundial (Camara, 2008). Os fungos são os primeiros microrganismos a serem reconhecidos como patogênicos, e doenças como a cólera eram suspeitas desses microrganismos. Hoje, sabe-se que a doença é causada por bactéria (Ainsworth, 1993).

Entre 1920 e 1929, a micologia norte-americana passou por transformações significativas com a criação do primeiro laboratório de micologia médica, estabelecido por dermatologistas e não mais por bacteriologista. (Ana Espinel-Ingrof, 1996). Em meados do século XIX, os avanços obtidos foram extraordinários, com desenvolvimento dos métodos de precisão para o estudo em laboratório (Benchimol, 2004, p. 47).

No Brasil, a pesquisa teve início com pesquisadores estrangeiros, entre eles o padre jesuíta Johannes Rick (1896-1946), que se estabeleceu no Rio Grande do Sul (Watling, 1988), porém, as pesquisas realizadas no país eram encaminhadas a outros centros como americano, francês e alemão. Os relatos de Fidalgo (1968) descreviam o conhecimento dos índios brasileiros sobre alguns tipos de fungos comestíveis e alguns alucinógenos.

De interesse mais específico, a micologia brasileira tem Silva Araújo como "o pai da micologia médica no Brasil". Ele realizou diversos estudos de micoses do homem e de animais, porém, foram as pesquisas de Adolph Lutz, na mesma época, que alavancaram essa área da micologia em nosso país (SchoenleinCrusius e Paula, 2004).

Os estudos realizados por Lutz tiveram uma influência direta na dermatologia brasileira, como descreve Benchimol (2004), quando nos fala sobre Lutz: “...e colocou seu vasto saber e sua mania de precisão a serviço dos que atuavam, agora mais diretamente na produção de conhecimentos originais sobre doenças de pele" (Benchimol, 2004, p.130-131).

$\mathrm{Na}$ dermatologia, os fungos cutâneos são denominados fungos dermatófitos. Sua descoberta foi intensa nas duas primeiras décadas do século XX, sobretudo na região norte do país. 
Um grande marco na micologia nacional foi a descrição, em 1919, por Parreiras Horta, da Madurella oswaldoi, o que revolucionou a dermatologia nacional, mantendo o Brasil como um grande centro de pesquisa em fungos (Schwartzman, 2001).

No início de 1913, foi instituída a disciplina de fungos patogênicos nas aulas de aplicação do Instituto, ministrada por Henrique Vasconcellos e frequentado por Olympio da Fonseca. Em 1922, juntamente com Arêa Leão, que descreveu espécies de fungos e publicou muitos trabalhos com Olympio da Fonseca, foi criada a seção de micologia do Instituto Oswaldo Cruz (Figura 4) (Camara, 2008).

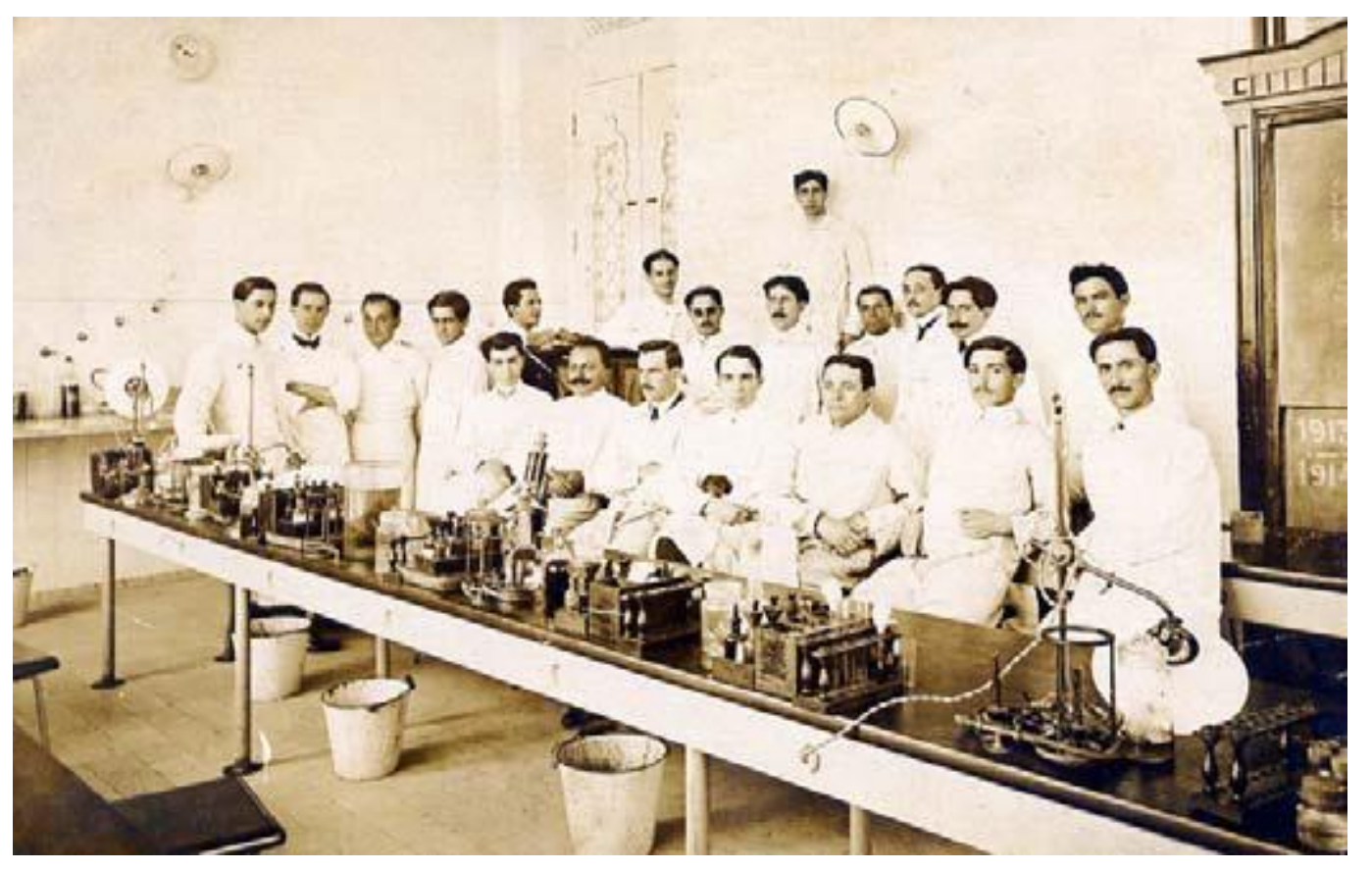

Figura 4 - Turma do Curso de Aplicação de 1913-1914 do Instituto Oswaldo Cruz. Olympio da Fonseca é o segundo da primeira fila, da direita para esquerda (Camara, 2008).

Foi durante a gestão de Carlos Chagas (1917-1934) que a coleção de fungos teve um grande incentivo, sendo que Olympio da Fonseca chefiou o laboratório de micologia até 1937, quando foi afastado por problemas políticos (Camara, 2008). A Seção de Micologia do Instituto Oswaldo Cruz ficou sob a 
chefia de Arêa Leão. A principal atividade do laboratório nesse período consistia na manutenção das culturas vivas, método esse que, até hoje, consiste na troca de meio de cultura, que fornece nutrição necessária para a manutenção do fungo vivo (Camara, 2008).

Em 1950, o V Congresso Internacional de Microbiologia foi realizado no Rio de Janeiro e contou com a participação de pesquisadores de todas as partes do mundo, entre eles, Alexander Fleming, e uma vasta produção de artigos. Em 1953 foi publicado um catálogo sobre fungos brasileiros e a produção científica foi mantida até a década de 60, até que, em 1970, o Instituto Oswaldo Cruz enfrentou um dos episódios mais dramáticos de sua história com a perda de incentivo governamental e perseguição política a vários pesquisadores (Camara, 2008).

Quanto aos fungos filamentos, o Instituto Oswaldo Cruz, em 2005, recebeu uma coleção destes, onde estão depositadas onze cepas de amostras do patrimônio genético nacional, coletadas em dípteros (moscas) na Amazônia (Camara, 2008).

Em 2012 a coleção de fungos filamentosos completou 90 anos, com um acervo com 2,1 mil cepas fúngicas dividido em 179 gêneros e 418 espécies, dentre elas 35 cepas tipo, algumas delas de grande importância histórica, como a cepa original de Alexander Flemining de Penicillium notatum, cedida pelo Instituto Butantã (Fiocruz, 2015).

Em relação às patologias desenvolvidas por fungos filamentosos, a Organização Mundial de Saúde (OMS) determinou que 150 unidades formadoras de colônias (UFC) por metro cubico (m3) é o limiar do qual pode-se desenvolver efeitos adversos na saúde humana, principalmente quando nos referimos às espécies patogênicas, relação esta que pode se agravar quando em ambientes de alta produção (Goyer, Lavoie e Lazure, 2001).

Um meio de propagação de fungos patogênicos ocorre pela dispersão no meio ambiente através do ar atmosférico ou por outras vias secundárias como água, insetos, homem e animais. O elemento fúngico disperso através do ar atmosférico é denominado de esporos (propágulos), assim, uma microbiota 
fúngica anemófila pode ser semelhante ou diferente em cada cidade ou região (Becker, 1994) A disseminação dos esporos depende de suas dimensões e características biológicas, além da temperatura do ar, disponibilidade de oxigênio, presença de nutrientes e da textura (Gomes, 2013; Lugauskas e Krikstaponis, 2004). A transmissão homem a homem não é comum, porém ocorre em aglomerados como creches, asilos, seminários (Becker, 1994).

Segundo a OMS, os fungos se encontram entre os cinco parasitas causadores de morte de origem microbiana no mundo, tornando-os um grupo de expressão nas patologias humanas (Tortora et al., 2002). Existem grupos desse microrganismo que vivem em meio ambiente vegetal e que podem contaminar a espécie humana (Esposito e Azevedo, 2010).

Os fungos também contribuem de forma positiva para os seres humanos, através de pesquisas de novos antibióticos, imunossupressores, antineoplásicos, herbicidas, antihelmínticos e inseticidas (; Esposito e Azevedo, 2010; Li et al., 2007).

No Brasil, os trabalhos em relação aos fungos e os seres humanos são em menor número e voltados à parte respiratória e em relação ao meio ambiente (Mezzari, 2003). No setor agropecuário os fungos estão presentes, sendo que na cana-de-açúcar eles podem trazer prejuízos expressivos tanto financeiros como em humanos (Embrapa, 2009).

Entre as doenças fúngicas da cana que trazem preocupações clínicas estão a Podridão-de-Fusarium e Pokkah-Boeng (Fusarium moniliforme e Fusarium moniliforme var. subglutinans) (Tokesshi, 1997). Essas patologias foram registradas em várias regiões do país e esses fungos podem eventualmente colonizar a espécie humana, tornando-se importantes agentes em algumas patologias, principalmente a de fundo alérgico (Figura 5) (Ribeiro, 2008). 


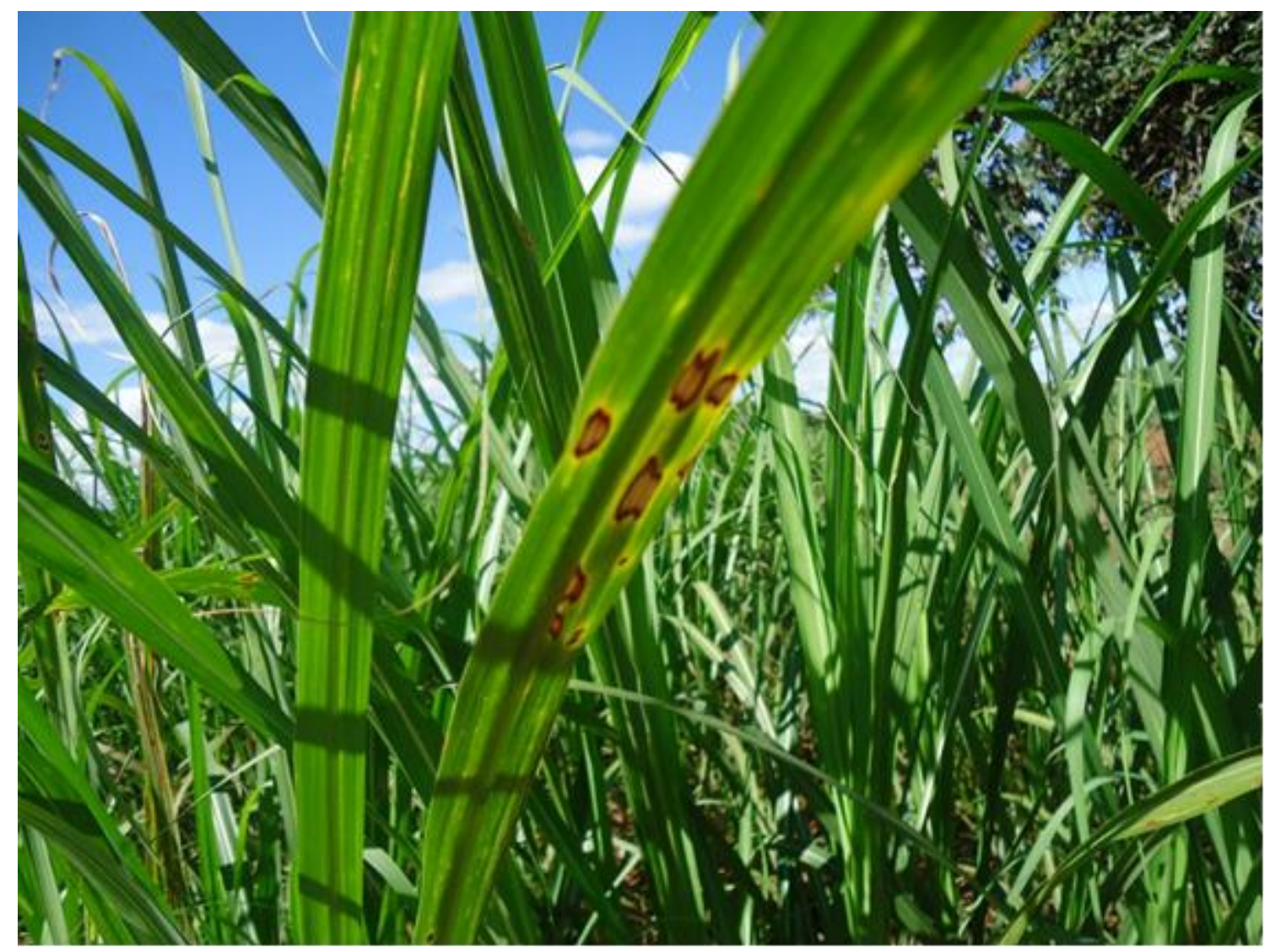

Figura 5 - Contaminação da cana-de-açúcar em planta adulta.

\subsubsection{Alguns gêneros de fungos filamentoso de importância clínica}

Considerando apenas os aspectos morfológicos, os fungos são separados em leveduriforme e em filamentosos (Murray, Rosenthal e Pfaller, 2006). Nos fungos filamentosos, que são os de interesse desta pesquisa, a estrutura vegetativa é constituída por filamentos ou hifas, que do crescimento resulta o micélio (Fischer e Cook, 1998). Em meio sólido denominam-se hifas vegetativas, quando em crescimento vertical e quando o crescimento é projetado por cima da superfície do meio, denominam-se hifas aéreas. As hifas aéreas podem produzir conídios (elementos da reprodução assexuada), que são facilmente transportados pelo ar e servem para disseminarem os fungos (Murray, Rosenthal e Pfaller, 2006; Esteves, Cabrita e Nobre, 1990; Fischer e Cook, 1998). 
A microbiota fúngica sofre alterações no campo quantitativo e qualitativo em função de vários fatores e, entre eles, os de âmbito ambiental como industrialização, aumento da densidade demográfica, desenvolvimento urbano, fatores geográficos associados às condições climáticas, temperatura, fatores sociais, observando a higiene, estado nutricional, pré-disponibilidade orgânica e sistema de saúde (Aquino et al., 2007). Através da secreção de enzimas no meio ambiente, interferem nos ciclos biológicos ambientais sendo responsáveis por deterioração de vários materiais naturais, processados ou refinados (Bennett, 1998).

No Estado de Minas Gerais, Faria, em 1987, identificou fungos no meio ambiente com uma frequência disposta em: Cladosporium (90,3\%), Penicillium (64,7\%), Aspergillus (58,6\%), Curvularia (33,3\%), Pullularia $(31,9 \%)$ e Epicoccum (31\%). Mas o fato que mais chamou atenção caracterizou-se quando, pela primeira vez, se encontrou frequência elevada de sensibilização ao gênero Alternaria $(21,1 \%)$ fato que, até então, não havia sido relatado no Brasil (Faria, 1987).

Apesar da exposição aos fungos serem, na maioria das vezes, acidental, muitos destes organismos desenvolveram mecanismos que facilitam a sua sobrevivência e reprodução num ambiente hostil (Sousa, Franco e Rodrigues, 2001). Devido a essa diversidade ambiental, os fungos filamentosos, segundo Costa et al., (2002), aumentam na população o risco de contaminação em 15\% de desenvolver alguma patologia fúngica durante sua vida. Alguns gêneros apresentam uma prevalência maior no meio ambiente e, por sua vez, em contato com a população, aumentando ainda mais o risco de doenças:

\section{A - Fusarium}

O gênero Fusarium possui diversidades em todo o planeta, e pode sobreviver por longos períodos de forma saprófita em material orgânico (Gupta, Baran e Summerbell, 2000). É uma das espécies com maior relevância, sendo considerada uma das mais importantes na fitopatologia mundial (Marin et al., 2004). É classificado como fungos mitospóricos da classe Hyphomycetes da 
subdivisão Deuteromicotina, uma vez que não possui o estágio sexuado identificado, o que é necessário para uma distinção taxonômica (Marin et al., 2004). Possui uma ampla distribuição geográfica, podendo ser encontrado em praticamente todos os ambientes. As colônias são geralmente de crescimento rápido, pálido ou coloridos (dependendo da espécie) e podem ou não ter um cotanilhoso micélio aéreo. A cor do talo varia de esbranquiçada a amarelo, marrom, rosa, avermelhada ou tons de lilás. Espécies de Fusarium normalmente produzem tanto macro quanto microconidia de fiálides delgado. Macroconídios são hialinos, dois a vários unicelular, fusiform - a forma de foice - e, na sua maioria, com uma célula apical alongada e pedicellate basocelular. Microconïdios são de 1 a 2 unicelular, hialina, piriforme, fusiforme a ovóide, em linha reta ou curva (Domsch et al., 1980).

Caracteriza-se por apresentar um crescimento rápido e colônias com coloração pálida ou colorida (violeta à púrpura escura ou creme à laranja), com micélio aéreo e difuso (Domsch et al., 1980). As colônias de Fusarium sp apresentam colônia filamentosa algodonosa branca e reverso lilás. Estes fungos dispersam seus propágulos no ambiente por ação da água da chuva, ventos e insetos. A maior parte das espécies do gênero parasita sementes de cereais, plantas, colmos e outros frutos do campo, causando danos à agricultura (Mills, 1989).

Até a década de 70 era considerado apenas causador de patologias superficiais. A partir desse momento, sua importância aumentou consideravelmente com a contaminação em pacientes imunossuprimidos (Guarro e Gene, 1995).

Algumas espécies podem causar infecções em mucosas, onicomicoses e também atingir a camada córnea do olho causando ceratite (Rocha et al., 2014; Gupta, Baran e Summerbell, 2000; Walsh e Dixon, 1996). Esse gênero também pode produzir uma ampla quantidade de toxinas, sendo que algumas delas são substâncias que têm sido relacionadas a vários efeitos adversos em animais e em seres humanos (Rocha et al., 2014; Sweeney e Dobson, 1996), agindo como neurotoxinas, agentes carcinogênicos, estrogênicos e uterotrópicos (Sorensen e Elbaek, 2005). Uma das mais importantes toxinas produzidas por esse grupo é 
a fumonisinas, embora já tenha sido detectada e isolada a partir de fungos do gênero Alternaria (Soriano e Dragacci, 2004). É a mais encontrada como contaminante natural de produtos alimentícios, causadora de edemas pulmonares em porcos e pode apresentar efeitos hepatocarcinogênicos em animais e humanos (Rocha et al., 2014; Rumor et al., 2002).

\section{B - Alternaria}

O gênero Alternaria consiste do fungo ascomiceto, conhecido por sua ampla distribuição e por suas características saprófitas e parasitárias, sendo associado a vários tipos de patologias (Pavon et al., 2012). Apresenta colônias de cores escuras, cinza, oliváceos, marrom ou preto. Seus conidióforos são macronematosos, mononematous, simples ou ramificada, marrom claro ao escuro. A célula conidiogênese é integrado, terminal ou intercalar, geralmente simpodial. Os conídios são muito característicos por sua forma longitudinal, transversal ou septados. Sua superfície pode ser lisa ou áspera (Index Fungorum, 2010).

Dentro desse gênero, a espécie de maior interesse é a Alternaria alternata, considerada um agente patogênico comum em safras de alimentos (Kosiak et al., 2004). A presença desse microrganismo também tem sido considerada um dos fatores etiológicos para o desenvolvimento de câncer de esôfago em humanos (Kosiak et al., 1996).

Considerado um alergênico importante da parte respiratória, também está associada à febre e reações de hipersensibilidade incluindo pruridos e dermatites inespecíficas. É um fungo que atinge com maior freqüência as mucosas (Pati et al., 2008). Grant, em 1998, descreveu em seus estudos a contaminação doméstica da Alternaria, principalmente na boca, nariz e olhos. 


\section{C - Cladosporium}

O gênero Cladosporium é um dos mais comuns, com ocorrência em todas as partes do mundo. Possui 734 espécies registradas válidas na literatura, apresentando 73 variedades e 40 formas especiais (Index Fungorum, 2010). No Brasil são conhecidos 26 gêneros de Cladosporium (Embrapa, 2010).

Formam colônias de coloração cinza ou marrom, às vezes da cor de azeitona; aveludadas, flocosas ou peludas. Seus conidióforos são macronematosos simples ou semimacronematosos ou pouco ramificada, com uma coloração marrom-esverdeada, e superfície lisa ou ligeiramente granulado em algumas espécies (Index Fungorum, 2010).

O fungo é encontrado como saprófita, contaminante do ar e alimentos, endofítico com função biológica importante na decomposição de matéria orgânica, sendo também forte competidor com outros microrganismos (Samson et al., 2000). Com frequência é encontrado em meio cosmopolita, o que reforça sua disseminação em micro e macro ecossistemas, principalmente quando associados ao clima de regiões temperadas (Al-Subai, 2002). São considerados importantes alergênicos, inclusive da parte cutânea. Cerca de $20 \%$ da população do EUA desenvolvem doenças alérgicas, como a asma e a rinite em alguma fase da vida, sendo atribuídos a este gênero (San Miguel et al., 2006). São raramente patogênicos aos seres humanos, mas foram relatados às infecções de pele e das unhas dos pés e sinusite e infecções pulmonares (Rivas e Thomas, 2005).

\section{D - Aspergillus}

Aspergillus é um gênero muito vasto com mais que 339 espécies, sendo um fungo filamentoso aeróbico, cosmopolita e ubiquitário (Prakash e Jha, 2014).

Foi catalogado em 1729 pelo padre italiano e biólogo Pietro Antonio Micheli. Observando o fungo no microscópio, Micheli lembrou-se da forma de um aspergillum (borrifador de água santa), e nomeou a espécie de acordo com o objeto. As espécies de Aspergillus são aeróbicas e encontradas em ambientes 
ricos em oxigênio, onde geralmente crescem na superfície onde vivem (Denison e Carroll, 1966).

O gênero Aspergillus sp. apresenta anamorfos (fases assexuada ou mitótica) de ascomicetos da ordem Eurotiales, subgênero Circumdati, classe dos hyfomicetes, seção niger (Index Fungorum, 2010). Segundo Chalfoun e Batista (2003), os gêneros são caracterizados pela produção de fiálides e conídio em cadeia seca, sendo seu conidióforo simples, sem ramificação, terminando em uma vesícula onde ficam inseridas as fiálides. Sua forma teleomórfica é considerada Eumycota, subdivisão Ascomycotina na ordem Eurotiales, produzindo através da reprodução sexual os ascósporos.

As espécies de Aspergillus contaminam restos de comidas (como pães e batatas) e crescem em muitas plantas e árvores. Esses fungos filamentosos são saprófitas, sendo utilizados na produção de alimentos e produção comercial de ácido cítrico, glucônico e gálico. Existem mais de 200 espécies encontradas na natureza (Kaneko e Sagara, 2006). Trabalhos como o de Kumar, em 1999, demonstram que esses fungos também participam do mecanismo de biodeterioração de rochas calcárias e arenitos (Kumar e Kumar, 1999).

O gênero Aspergillus é um fungo cujos conídios estão presentes no ar e possui mais de 200 espécies, 11 variedades e 9 formas especiais válidas na literatura e distribuídas na natureza (Index Fungorun, 2010). São ubiquitários, têm tendência para crescer em matéria orgânica de até $37^{\circ} \mathrm{C}$ (Anaissie et al., 2009). Os conídios ou esporos existentes nesses fungos são facilmente libertados na atmosfera e possíveis fontes de transmissão da doença (AbuElteen, Hamad, 2012). Normalmente não causam doenças muito sérias, entretanto, um indivíduo com um status imunológico debilitado pode apresentar reação com manifestações clínicas que vão desde reações de hipersensibilidade (aspergilose alérgica) até formas pulmonares e cerebrais (aspergiloma ou bola fúngica), culminado em morte (Amorin et al., 2004).

Uma das mortes mais famosas por Aspergillus do gênero nigrans foi de membros da equipe do arqueólogo Howard Carter, descobridor da tumba do Faraó Tutancâmon, cheia de mistérios e atribruições à maldição do Rei Tuti. $O$ 
que comprovou as mortes foi o diagnóstico de Charriel Manson, portadora de Linfoma Hodgkin que faleceu três semanas após ter colocado as mãos nas pinturas da tumba. David Silverman, também da equipe, através de biopsia pulmonar, constatou que ele fora contaminado por fungo - Aspergillus niger desmistificando a maldição (Winstone, 1991).

Muitas outras funções são realizadas por esse gênero de fungos das quais podemos citar a formação de compostos para refrigerantes, que, quando o amido de milho é misturado com uma enzima segregada por um bacilo - uma bactéria em forma de haste - e outra enzima segregada por um fungo a fermentação ocorrida cria um gosto sui generis, agradando ao paladar de grande parte da população (Baker e Benneth, 2008).

\subsection{A cidade de Frutal}

\section{- Origem do nome}

Em 4 de outubro de 1887, através da Lei № 3.436, Carmo do Fructal foi "emancipada" do município de Uberaba e elevada à categoria de "cidade" com o nome de Frutal, graças ao trabalho do Comendador Gomes, já eleito Deputado e Senador conhecido como Senador Gomes da Silva (Prefeitura de Frutal, 2016).

O topônimo Frutal está ligado à abundância, nas margens dos ribeirões, de uma fruta semelhante à jabuticaba e que era conhecida simplesmente por "fruta", dando-se à região, inicialmente, reconhecimento como Patrimônio das Frutas e, posteriormente, como Carmo do Fructal. Hoje é conhecido como município de Frutal - MG (City Brasil, 2015).

O desenvolvimento das culturas de abacaxi e laranja teve uma relevante contribuição para que o município recebesse o título de "Cidade das Frutas", influenciando diretamente no desenvolvimento socioeconômico da cidade com uma oferta significativa de empregos (Oliveira e Mendes, 2014). Porém o crescimento demográfico ocorreu apenas a partir da década de $1990 \mathrm{com}$ a 
expansão da área cultivada no município. A maior demanda foi observada nessas duas culturas, baseada na produção de laranja (517.725 toneladas de laranjas/ano) e abacaxi (127.000 toneladas/ ano), mesmo após a introdução da cana-de-açúcar, que produziu cerca de 416.000 toneladas de frutas em 2010 (Secretaria da Agricultura, 2011).

\section{- Dados gerais sobre o município de Frutal - MG}

O município de Frutal localiza-se na região oeste do Estado de Minas Gerais (Figura 6). Na divisão administrativa de Minas, está na Região Administrativa Triângulo e Alto Paranaíba, pertencente à Macrorregião de Planejamento IV, à Mesorregião do Triângulo Mineiro e à Microrregião de Frutal.

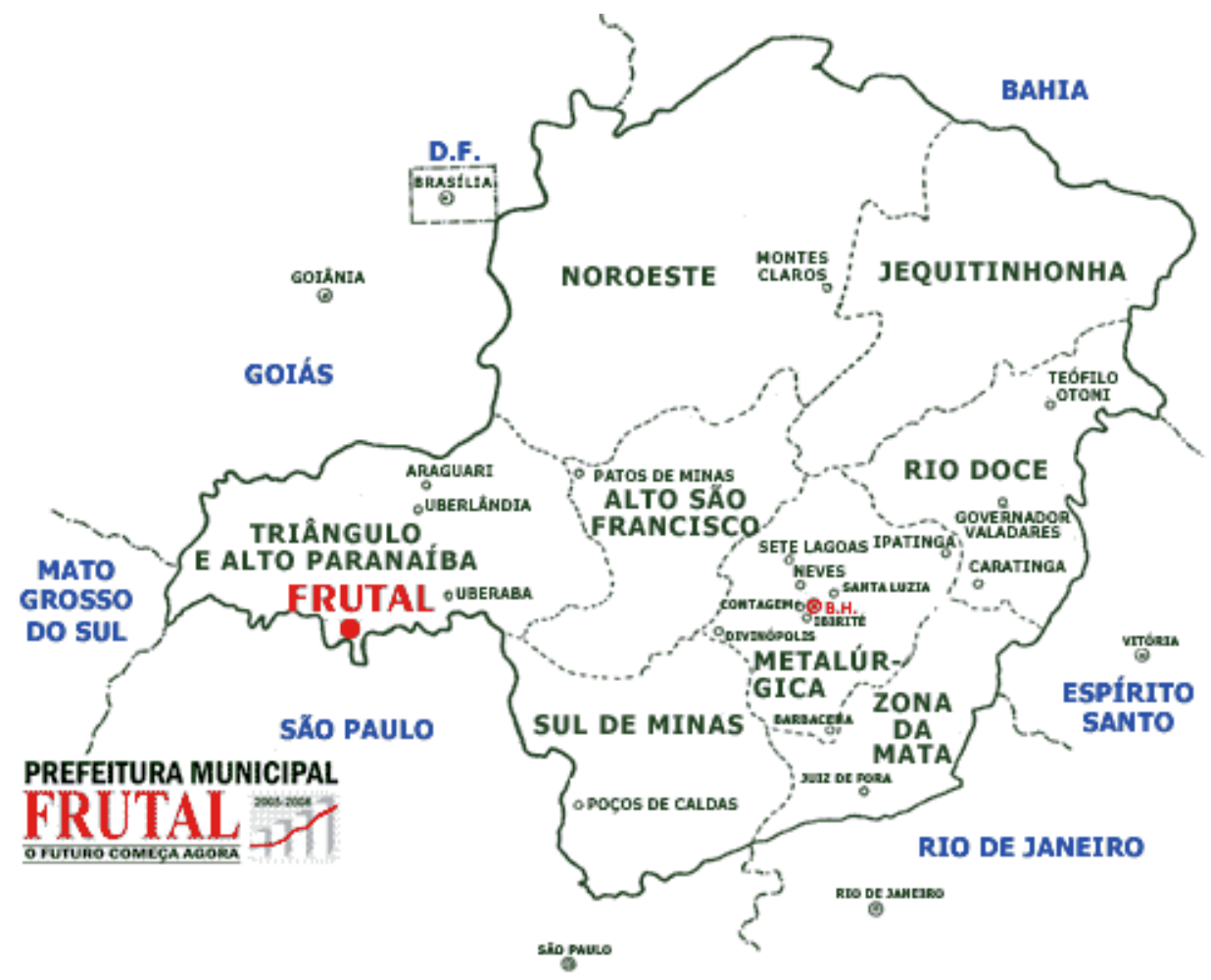

Fonte: Prefeitura Municipal de Frutal, 2009.

Figura 6 - Localização da cidade de Frutal.

A região do Triângulo Mineiro, onde Frutal está localizada, compreende 33 municípios distribuídos entre as Microrregiões de Itutiutaba, Uberlândia, Frutal e Uberaba. A Microrregião de Frutal conta com os municípios de Campina Verde, Carneirinho, Comendador Gomes, Fronteira, Frutal, Itapagipe, Iturama, 
Limeira do Oeste, Pirajuba, Planura e São Francisco de Sales. O município de Frutal se localiza a oeste do Planalto da Serra Geral, que separa as águas do Rio Grande e São Francisco na parte sul da macrorregião, fazendo divisa com o estado de São Paulo.

Com uma área de $2.430 \mathrm{Km}^{2}$, o município se localiza a $20^{\circ} 01^{\prime} 29^{\prime \prime}$ de latitude sul e a $48^{\circ} 56^{\prime} 25^{\prime \prime}$ de longitude oeste (Figura 7). A população total é de aproximadamente 53.474 habitantes, baseado na estimativa da população para 2011 (Senso parcial de 2010 - IBGE), sendo 27.074 homens e 26.400 mulheres.

O clima dominante na região é o tropical com uma estação de seca e média anual de temperatura de $25,2{ }^{\circ} \mathrm{C}$. A média máxima anual é de $31,7^{\circ} \mathrm{C}$ e a média mínima anual é de $18,2 \stackrel{\circ}{\circ}$. O índice médio pluviométrico anual é de 427 $\mathrm{mm}$.

O relevo tem uma topografia com $50 \%$ de área plana e $50 \%$ de terreno ondulado, propícios ao plantio da cana-de-açúcar.

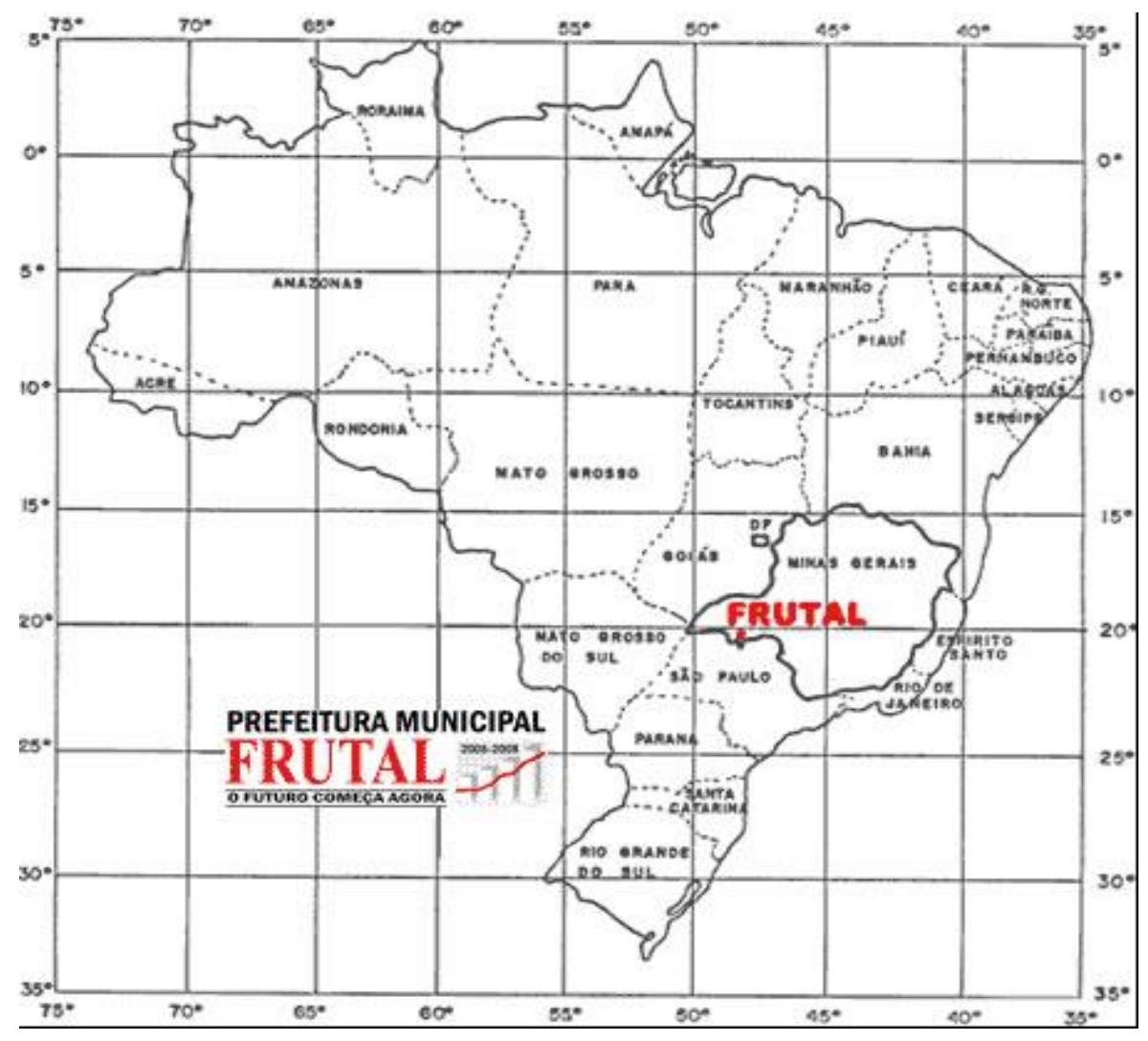

Fonte: Prefeitura Municipal de Frutal, 2009.

Figura 7 - Localização da cidade de Frutal na Macrorregião. 


\section{OBJETIVOS}

\subsection{Objetivo Geral}

Avaliar a incidência de fungos filamentosos na mucosa oral normal de trabalhadores rurais das culturas de cana-de-açúcar, abacaxi e laranja da região de Frutal - MG.

\subsection{Objetivos Específicos}

Descrever demograficamente os participantes do estudo em relação ao sexo, raça e condição socioeconômica;

Avaliar a incidência de fungos filamentosos na mucosa oral de trabalhadores da cana-de-açúcar ao longo do período de trabalho de sua colheita;

Avaliar a incidência de fungos filamentosos na mucosa oral de trabalhadores da laranja ao longo do período de trabalho de sua colheita;

Avaliar a incidência de fungos filamentosos na mucosa oral de trabalhadores do abacaxi ao longo do período de trabalho de sua colheita;

Investigar fatores associados à presença de infecções fúngicas filamentosas nos trabalhadores das três culturas;

Identificar os fungos filamentosos no meio ambiental das três culturas analisadas. 


\section{MÉTODOS}

Este é um trabalho longitudinal, prospectivo, tipo coorte, não randomizado, para avaliar a incidência de contaminação fúngica em mucosa oral normal em três populações agrícolas distintas do município de Frutal, Minas Gerais. As culturas analisadas foram cana-de-açúcar, abacaxi e laranja.

\subsection{Cálculo de tamanho de amostra}

Pela importância do agronegócio e das culturas de cana-de-açúcar, abacaxi e laranja na região do município de Frutal - MG, optou-se em analisar trabalhadores migrantes dessas atividades agrícolas para que pudesse ocorrer uma diminuição na interferência ambiental por exposição profissional a longo prazo. Além disso, o trabalhador migrante tem como característica a jovialidade, o que não significa apenas ter força e resistência física, fator indispensável para enfrentarem a rotina e a disciplina no trabalho (Rosa e Navarro, 2014).

Devido à falta absoluta de estudos avaliando a incidência de infecção fúngica filamentosa em mucosa oral de trabalhadores rurais, o cálculo do tamanho da amostra foi baseado na experiência profissional do pesquisador executante, a única dermatologista na experiência clínica na região administrativa do município em questão. Como o cálculo da amostragem depende de apenas duas proporções e foi percebido na clínica diária que a infecção fúngica na mucosa oral dos trabalhadores do abacaxi era três vezes mais frequente que entre os trabalhadores da laranja, portanto, uma diferença de incidência de trinta para dez por cento (30\% em oposição a 10\%), adotou-se um teste bicaudal com poder de $80 \%$ e nível de significância de $5 \%$, estimandose um número de 60 trabalhadores em cada grupo analisado. Portanto, foram convidados a participar do estudo 60 trabalhadores provenientes do nordeste brasileiro para trabalho temporário nos campos de cana-de-açúcar de ambos os sexos, 60 trabalhadores de laranja e 60 de abacaxi também de ambos os sexos, contratados temporariamente para o período da safra, provenientes de outras regiões do Triângulo Mineiro. 
Os trabalhadores que concordaram em participar do estudo após a explicação dos objetivos e dos procedimentos envolvidos no estudo assinaram o termo de consentimento livre e esclarecido (ANEXO C).

\section{A - Raça}

Usamos os critérios baseados em Fitzpatrick (2011) que classifica em leucodérmicos os que se definem como brancos; faiodérmicos os mulatos e melanodérmicos os negros, segundo o tom da pele.

\section{B - Ingestão alcoólica e tabagismo}

Estudos populacionais brasileiros sobre o alcoolismo mostram que ele está negativamente associado com a situação socioeconômica, educação, ocupação e renda (Brasil, 2012). Essa ingestão é considerada um fator de risco para o desenvolvimento de patologias na cavidade bucal, principalmente se 0 uso for combinado com o tabaco (Brasil, 2016; Longo et al., 2013). O tabagismo, por sua vez, altera os microbiomas da região de orofaringe (Morris et al., 2013), sendo considerado um grave problema de saúde pública (Brasil, 2012). O hábito de fumar ocasiona importante aumento no risco de desenvolvimento de doenças em diversos sistemas do organismo, inclusive na região de orofaringe (Messner e Bernhard, 2014).

Apesar do uso do tabaco, consumo excessivo de álcool, má alimentação e falta de atividade física aumentarem o risco de desenvolvimento de doenças cardiológicas, pulmonares, entre outras (Ezzati e Riboti, 2013), as avaliações sobre o uso delas apresentam uma limitação em diversos estudos, pois essas informações sobre o consumo são frequentemente autorreferidas, sendo assim, é possível algum grau de subestimação, onde a boa confiabilidade não garante a validade (Stelmac et al., 2015; Lima et al., 2013; Chor et al., 2003).

Neste estudo optou-se, então, por considerar uma variável dicotômica exploratória apenas de exposto e não exposto para estes dois itens, sem levar 
em consideração a quantidade de tabaco e/ou de álcool consumidos (Giolo, 2012; Lemos, 2010; de Bragança, 1977).

\subsection{Fatores de inclusão}

Para todos os participantes:

- Ter idade entre 21 e 40 anos;

- Serem migrantes vindos para atividades laborais nas referidas safras. Acredita-se que seria uma avaliação mais fidedigna, pois se os participantes estivessem estabelecidos no município em questão por um tempo mais prolongado o contato ambiental poderia influenciar e comprometer os resultados;

- Não apresentar doenças na mucosa oral no momento da seleção;

- Não apresentar doenças imunodebilitantes diagnosticadas durante anamnese e/ou por exames de rotina solicitados pelas empresas no período admissional pré-safra, os quais foram fornecidos espontaneamente pelos participantes do estudo. Os indivíduos que não forneceram os exames não foram incluídos neste estudo, dado à dificuldade de se comprovar alguma doença debilitante diagnosticável pelos resultados;

- Não estar usando medicações como: anti-inflamatórios não hormonais e hormonais, antibióticos, antifúngicas, medicações de bochecho e imunossupressores (Ortiz et al., 2011; de Hoog et al., 2001);

- Não ter realizado tratamento dentário até três meses antes do início do estudo (possível contaminação instrumental ou por reação secundária) (Oliveira et al., 2011);

- Não ter tido internação hospitalar em período de até seis meses antes do início do estudo;

- Já ter realizado exames admissionais, pelas empresas, na présafra, como hemograma completo, glicemia, urina 1 (EAS). 


\section{A - Fatores de inclusão para trabalhadores da cana}

- Trabalhadores migrantes do nordeste brasileiro que se encontram estabelecidos na cidade há, no máximo, três meses antes do início do trabalho.

B - Fatores de inclusão para os trabalhadores de laranja e abacaxi

- Trabalhadores que se encontram na cidade para a safra dessas culturas e que sejam provenientes do Triângulo Mineiro;

- Terem permanecido no município por, no máximo, três meses antes do início do trabalho.

\subsection{Fatores de exclusão}

- Ter sido desligado da empresa durante a fase da pesquisa;

- Todo indivíduo que, após concordar com o estudo, desistisse desta participação.

\subsection{Fatores de encerramento}

A pesquisa teria seu encerramento prematuro se o número da amostra se tornasse inexpressiva.

\subsection{Condutas aos possíveis contaminados}

Os participantes que por ventura apresentavam qualquer alteração em orofaringe antes da seleção dos participantes ou durante a investigação da mucosa oral foram encaminhados aos serviços de referência para as condutas clínicas adequadas. 


\subsection{Fases da coleta no período das culturas}

Todos os trabalhadores das três culturas foram contactados e admitidos nesta pesquisa após terem sido admitidos como trabalhadores temporários nas culturas a que se destinavam.

\section{A - Trabalhadores da cana}

As amostras foram colhidas em três tempos:

- Tempo zero (to): durante o período admissional; fevereiro a março de 2013;

- Tempo um ( $\left.\mathrm{t}_{1}\right)$ : dois meses após o início dos trabalhos nos campos de cana realizados no período de abril a maio de 2013;

- Tempo dois ( $\left.\mathrm{t}_{2}\right)$ : quatro meses após o início dos trabalhos nos campos realizados no período de junho e julho de 2013.

\section{B - Trabalhadores da laranja}

As amostras foram colhidas em três tempos:

- Tempo zero (to): durante o período admissional; abril a junho de 2013;

- Tempo um ( $\left.\mathrm{t}_{1}\right)$ : dois meses após o início dos trabalhos nos campos de laranja realizados entre julho e agosto de 2013;

- Tempo dois ( $\left.\mathrm{t}_{2}\right)$ : quatro meses após o início dos trabalhos nos campos realizados entre setembro e outubro de 2013.

\section{C - Trabalhadores do abacaxi}

As amostras da mucosa oral foram colhidas também em três tempos:

- Tempo zero (to): durante o período admissional, nos meses de abril a junho de 2013; 
- Tempo um ( $\left.\mathrm{t}_{1}\right)$ : dois meses após o início dos trabalhos nos campos de abacaxi realizados nos meses de julho e agosto de 2013;

- Tempo dois ( $\left.\mathrm{t}_{2}\right)$ : quatro meses após o início dos trabalhos nos campos realizados nos meses de setembro e outubro 2013.

Este fluxo pode ser melhor visualizado na figura 8.

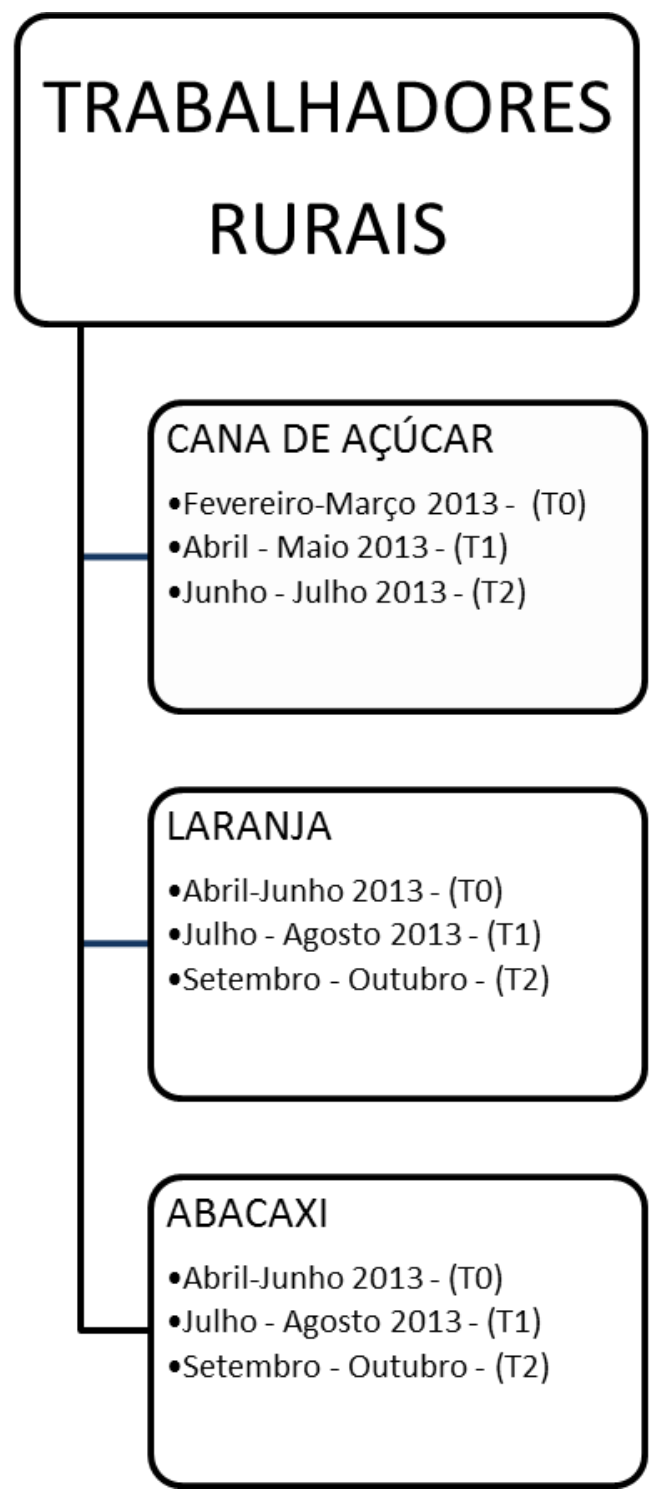

Figura 8 - Fluxo do estudo na linha-tempo. 


\subsection{Amostras e coletas}

A solicitação de agendamento com o laboratório se processou por telefone com conhecimento dos empregadores dos profissionais das três culturas. O número de exames diários dependeu da disponibilidade dos trabalhadores, do número agendado com o laboratório e da condição física do pesquisador. $\mathrm{O}$ exame clínico de todos os trabalhadores foi realizado por um único examinador. Foram utilizadas espátulas de swabs estéreis e iluminação direta em sala arejada para melhor visualização dos tecidos da cavidade bucal e suas possíveis alterações. Essa fase foi anotada em uma ficha específica (ANVISA, 2012; Danfré, 2007), (ANEXO A). Foi solicitado aos participantes que não realizassem escovação dentária e/ou bochechos antes do procedimento para que não houvesse perda de possível material contaminado. Aos participantes tabagistas e etilistas, tiveram esses dados anotados em seus relatórios.

Antes da coleta de material para análise, realizou-se uma inspeção da mucosa bucal e dos tecidos moles no interior da boca da seguinte ordem: mucosa labial e sulco labial superiores e inferiores; área labial das comissuras e mucosa bucal nos lados direito e esquerdo; margens alveolares; gengivas superior e inferior; palato; língua e assoalho bucal (Cruz et al., 2014; Castro et al., 2009) afim de decção de alguma lesão prévia à coleta.

A coleta de material investigativo baseou-se nas pesquisas de Arango e Castañeda (1995); Arendorf, Walker (1979), tendo sido colhido material da mucosa oral na região do sulco gengivo-labial, próximo à região do freio superior e freio inferior; material da mucosa jugal direita e esquerda, com um swab para cada região e dispostos na placa de Petri, respeitando a anatomia oral. $\mathrm{O}$ conteúdo foi semeado em placas de Petri com movimentos em estrias em zigzag para isolamento de possíveis contaminações, contendo um meio de cultura para fungos enriquecida com antibiótico - cloranfenicol (ASD). Foi utilizado um swab para cada meio, seguindo sempre a mesma sequência para cada coleta (Muñoz Burillo, Bouza, 2001). Após a coleta os swabs foram descartados no próprio laboratório. Foram usadas, em todas as fases da pesquisa, placas de 
Petri em vidro com medidas de $100 \times 15 \mathrm{~mm}$. A identificação das placas de Petri se deu com a colocação na tampa da data e nome do grupo.

\section{A - Agar Sabouraud Dextrose (ASD)}

O ASD é um meio básico em laboratório de micologia, também denominado simplesmente de Ágar Sabouraud. Trata-se de meio com nutrientes que, devido às altas concentrações de carboidratos, favorece o crescimento de diversos fungos leveduriformes e filamentosos (Pires, 2014; Tsai, Yang e Crandal, 2001; Sabouraud, 1892; Haley, Trandel, Coyle, 1980).

Em regra, usa-se um antibiótico para impedir o crescimento de bactérias que poderiam prejudicar $O$ isolamento de fungos. O cloranfenicol é o mais indicado, pois resiste à autoclavação. Pode ser colocado tanto no ASD como em outros meios de cultura para fungos (Pires, 2014; Colakoglu, 2004; Chao, Schwartz e Milton, 2002; Tsai, Yang e Crandal, 2001; Lugauskas e Krikstaponis, 2004; Lorian, 1991).

Nesta pesquisa, o meio de cultura para fungos foi adquirido através da importação do laboratório NEOGEN, 7306 A lote104, 985B (Figura 9). Após a hidratação conforme instruções do fabricante, o meio foi distribuído em placas de Petri em vidro com medidas de $100 \times 15 \mathrm{~mm}$ pela maior facilidade em adquirilas e esteriliza-las por autoclavação ( $121^{\circ} \mathrm{C}$ por 15 minutos a $1 \mathrm{~atm}$.). 


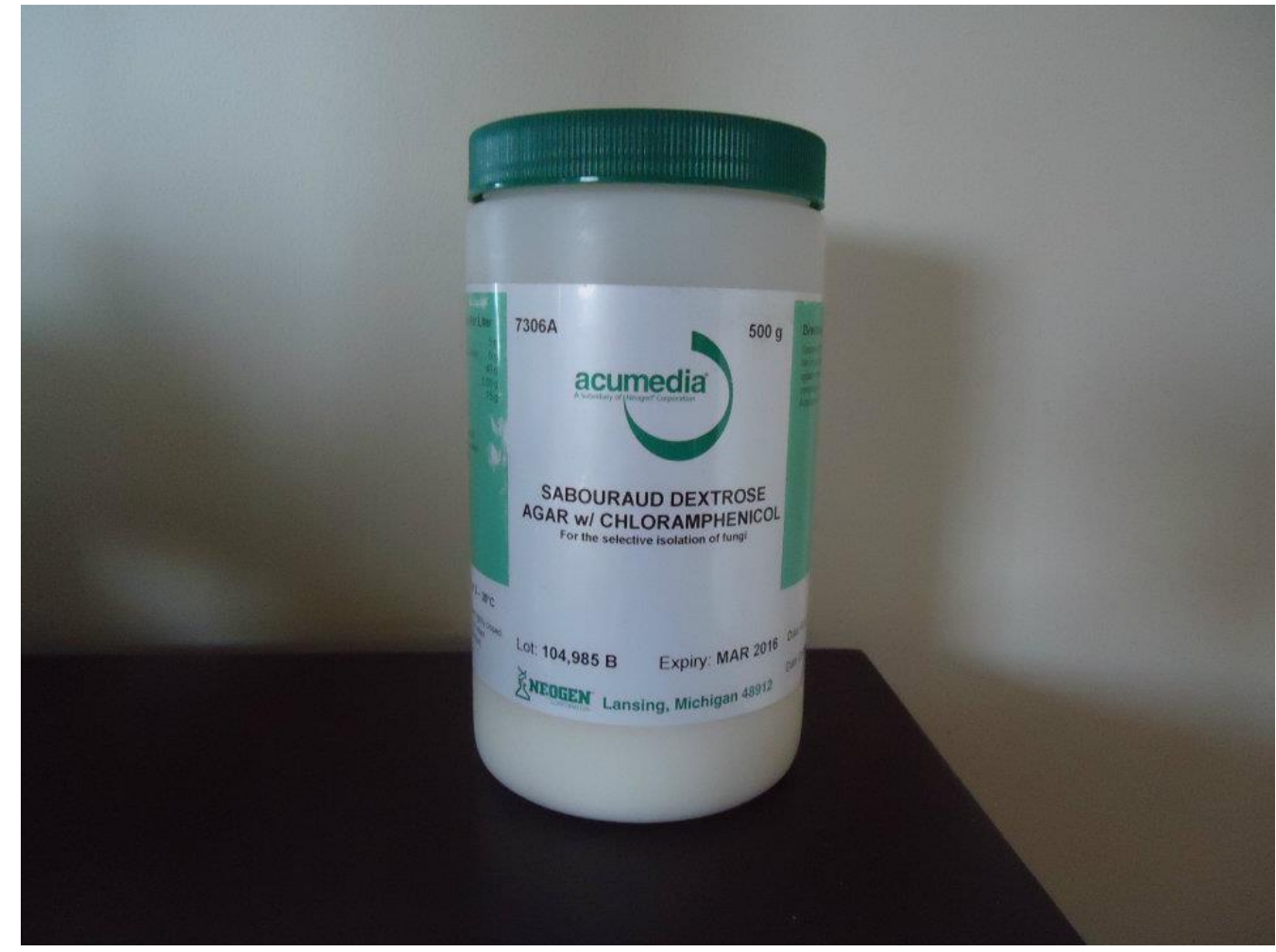

Figura 9 - Produto usado como meio de cultura para fungos.

\section{B - Identificação das amostras}

Cada indivíduo participante recebeu um número sequencial em algarismo arábico que o acompanhou durante toda a pesquisa. Essa determinação numérica foi de acordo com a concordância em participar da pesquisa. Além disso, as letras $\mathbf{C}$ foram utilizadas para definir os trabalhadores de cana-deaçúcar, L para os trabalhadores da laranja e A para os trabalhadores do abacaxi; os tempos definidos para colheita de material de estudo em ( $\left.\mathrm{t}_{0}\right),\left(\mathrm{t}_{1}\right)$, ( $\left.\mathrm{t}_{2}\right)$ também foram usados para caracterizar cada fase de coleta de cultura e análise das amostras.

\subsection{Exame do meio ambiente}

O exame do meio ambiente permite uma monitorização da exposição do trabalhador ao risco de contaminação, possibilitando estudos epidemiológicos e desenvolvimento de estratégias de controle da exposição (Sadhra e Gardiner, 
1999; Oliveira, 2010). O risco à saúde só pode ser medido quando avaliado o ambiente em que se encontra a população em estudo, pensamento esse confirmado por Prista e Uva (2006). Para que houvesse uniformidade nos parâmetros da pesquisa, no exame do meio ambiente e no exame das plantas foram utilizadas placas de Petri também em vidro com medidas de $100 \times 15 \mathrm{~mm}$, sempre realizados no período da manhã e nunca ultrapassando as dez horas, para que a interferência da temperatura e movimento humano pudesse influenciar os resultados. As condições climáticas do período eram anotadas para análise posterior.

Para que houvesse uma condição favorável e uniforme à pesquisa ambiental, foram escolhidos 4 alunos de graduação do grupo sucroalcooleiro da Universidade do Estado de Minas Gerais (UEMG) da iniciação científica, já previamente autorizado pela Universidade (ANEXO B).

Para o êxito dessa etapa houve um treinamento desses voluntários baseados em Carvalho e Nascimento (2012), Moscovici (1995) e Torello (1980), que descrevem a necessidade de treinamento do pessoal envolvido em atividades laborais. Assim, foi realizado um treinamento com os voluntários nas coletas ambientais descritas a seguir.

No mês de novembro de 2012, foram contactados os alunos residentes no município de Frutal e que faziam o curso acima descrito, sendo anotados os dados pessoais e contatos telefônicos, bem como e-mails para que no mês de janeiro e fevereiro de 2013, os que tivessem interesse pudessem realizar o treinamento proposto. A escolha e treinamento desses alunos se processaram da seguinte maneira: foram escolhidos dez voluntários do curso, moradores do município de Frutal e, após exposição do propósito da pesquisa e função dos participantes, procedeu-se o treinamento em campo para coleta do material. Foi escolhido um campo de cana-de-açúcar que não faria parte da área da pesquisa e com a supervisão de um funcionário técnico da usina, porém sem sua interferência na explanação e procedimento, demonstrou-se como seria a coleta em cada etapa. Esse treinamento funcionou como teste piloto e dos dez participantes iniciais os quatro que melhor se destacaram após o treinamento e que dispunham de tempo para a atividade proposta foram escolhidos para 
participar nesta pesquisa. Esse treinamento foi realizado nos meses de janeiro e fevereiro de 2013 - período de menores atividades estudantis, porém um período favorecido pela facilidade de acesso à cana-de-açúcar.

\section{$A-A r$}

A verificação ambiental da presença de fungos no ar tem sido descrita em diversos artigos, como os de Kozak, Gallup e Cummins (1980), Quezada e Lange (2004), Martins-Diniz, da Silva e Miranda (2005), Rodrigues e Araújo (2007), Sanchez, Munoz e Gonzalez (2009), entre outros, demonstrando a importância para a prevenção das contaminações. Como um método simples, mas eficiente, as colheitas de ar podem estimar a concentração de partículas fúngicas viáveis, viabilizando identificação dos locais de contaminação e as possíveis fontes (Tavora, Gambale e Heins-Vaccari, 2003).

Procurou-se observar as condições climáticas para que pudessem ser sempre dentro do mesmo padrão em temperatura e umidade do ar antes do início das atividades laborais, baseando-se em Piteira (2007). No dia das coletas foram expostas ao ar 10 placas de Petri contendo o meio de Sabouraud-glicose acidificado (SGA) em vários locais do canavial e nos campos de laranja e abacaxi, mas com uma distância aproximada de 500 metros cada um, a uma altura de 1,20 metros do solo, em repouso, por um período de 30 minutos em posição horizontal (Figura 10) (Lacaz et al., 1991; Oliveira et al., 1993). 


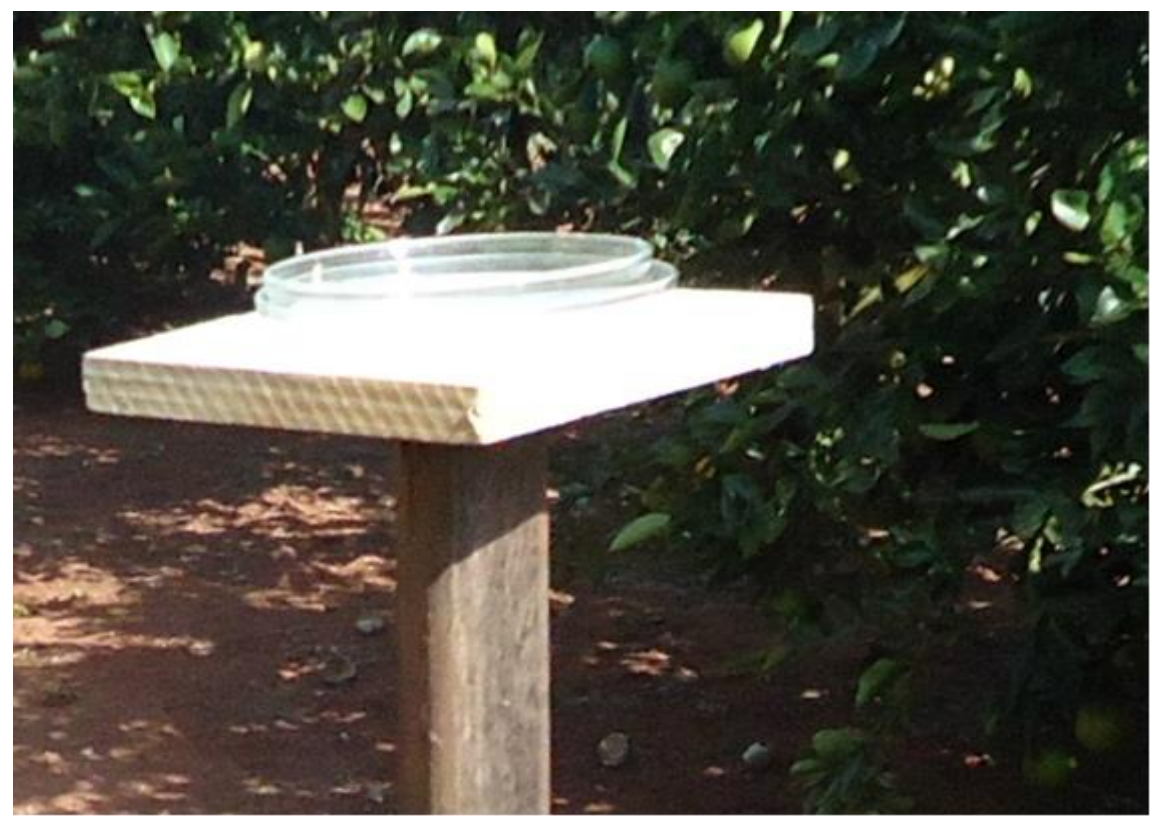

Figura 10 - Placa de exposição ambiental na cultura de laranja.

A primeira placa foi colocada em um ponto de fácil acesso no campo, nunca exposta em área de tráfego de veículos ou passagem de trabalhadores. Após a instalação da primeira, mediu-se um raio de 500 metros em torno da primeira placa, distribuindo as nove placas restantes seguindo o raio. Usou-se essa técnica no intuito de abranger uma maior região dentro da cultura a ser analisada (Figura 11). 


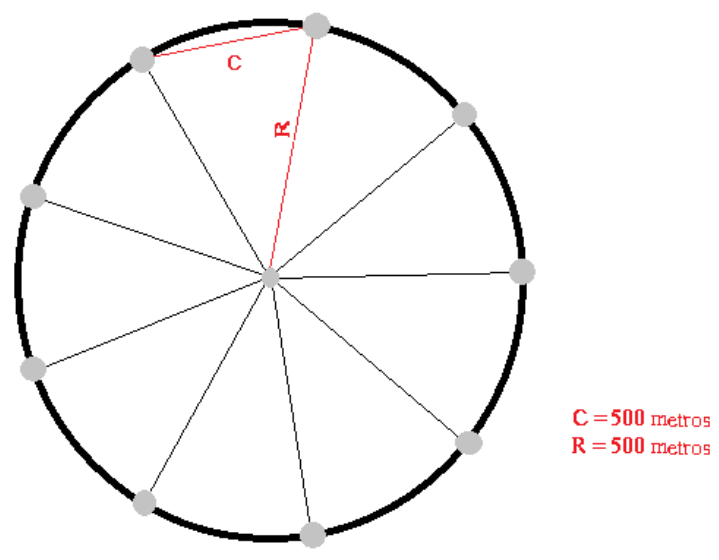

Figura 11 - Distribuição das placas de Petri nos campos das culturas.

Essa etapa foi repetida nos mesmos períodos em que foram realizadas as coletas nos trabalhadores de cana-de-açúcar, recebendo a mesma designação quanto aos tempos: ( $\left.\mathrm{t}_{0}\right),\left(\mathrm{t}_{1}\right),\left(\mathrm{t}_{2}\right)$. Levou-se em conta o número absoluto de colônias de fungos encontradas em cada placa, independente do tamanho da colônia (Silva e Junqueira, 1995). Essa exposição foi para estudo comparativo entre o material encontrado nos trabalhadores pesquisados e as possíveis interferências ambientais.

\section{B - Pesquisa nas folhas e colmos}

A pesquisa direta nas plantas pode identificar em torno de $17 \%$ dos fungos em um meio de cultivo simples (Tortora, et al., 2015; Nannipierri et al., 2003). Essa fase serviu para comparação do material encontrado nos pacientes colhidos e as possíveis contaminações da cana-de-açúcar.

Fez-se a opção de colocar numa mesma placa um fragmento de folha e de um talo do caule da mesma planta, porém de lados opostos, com tamanho 
aproximado de 0,2 cm cada (Nannipierri et al., 2003). As plantas em que foram colhidas as amostras estavam afastadas cerca de um metro da placa exposta do ambiente. A planta escolhida foi sempre a que se encontrava à direita do pesquisador quanto à posição anatômica. Se caso esta planta apresentasse algum indício de estar contaminada, era escolhida a do lado esquerdo do pesquisador, mantendo-se o padrão de análise.

Os fragmentos retirados das folhas e dos colmos das plantas foram semeados na superfície do meio SGA diretamente, sem nenhum tratamento prévio (Stuart, 2006). De cada planta, os fragmentos foram retirados com material previamente esterilizado.

Também se realizou em três tempos ((to), ( $\left.\left.\mathrm{t}_{1}\right),\left(\mathrm{t}_{2}\right)\right)$ a colheita de fragmentos da cana-de-açúcar para comparação com os resultados das outras etapas em três tempos ((to), ( $\left.\left.\mathrm{t}_{1}\right),\left(\mathrm{t}_{2}\right)\right)$ para as culturas da laranja e abacaxi.

Essa fase foi acompanhada pelo responsável técnico das plantações, porém sem interferência na coleta. Especificamente sobre a laranja, procuramos campos onde existiam as três fases, ou seja, pés adultos jovens já na primeira florada, pés em atividade e pés em última safra, o que na região ocorre com certa frequência devida sua característica frutífera. A renovação dos pés ocorre dentro dos padrões ambientais.

\subsection{Transporte e armazenamento}

Todas as amostras foram transportadas através de caixas térmicas previamente climatizadas, de uso comum, até o laboratório.

\subsection{Identificação de fungos filamentosos}

A identificação de fungos filamentosos tem como fundamento a observação da morfologia da colônia e aspectos microscópicos. A análise da colônia visa observar: cor, textura, superfície e pigmento difusível no meio de cultura e as estruturas microscópicas, forma e cor da hifa, presença ou não de 
septos, tipo e arranjo de esporos (Domsch et al., 1993; Pitt e Hocking,1985). Para realizar a leitura, as placas foram colocadas em suporte contendo espelho, permitindo a observação clara do reverso das mesmas.

\subsection{Procedimentos para cultura}

O material foi colocado apenas aderido à superfície do meio, $A S D$, que é o meio mais utilizado por ser relativamente barato e permitir o crescimento de todos os fungos com raríssimas exceções, sendo utilizadas placas de Petri com medidas de $100 \times 15 \mathrm{~mm}$.

A temperatura de incubação recomendada para todas as amostras é de $25^{\circ} \mathrm{C}$. Essa temperatura é verificada, mais facilmente, durante muitas horas do dia, o que favorece a adaptação dos fungos ao crescimento (Brasil, 2012).

Após o crescimento dos isolados, as culturas filamentosas foram submetidas às técnicas de colônias gigantes e microcultivo (Domsch et al., 1993; Steele e Stowers, 1991), para permitir melhor observação das colônias e de suas estruturas reprodutivas e, assim, poder identificá-los (Brasil, 2012; Trabulsi, Altathum, Gompertz, Candeias, 1999).

Baseando-se em Olbrich (2010), a colônia predominante foi semeada com o auxílio de uma agulha de níquel-cromo no ponto central da placa de Petri, que foi coberta com lamínula esterilizada num ângulo de 45 graus. $O$ conjunto foi colocado em estufa à temperatura de $25^{\circ} \mathrm{C}$ por sete dias. $\mathrm{O}$ crescimento foi anotado, e poderia variar de forma rápida (< 7 dias), intermediária (8 a 14 dias) ou lenta (> 15 dias). Essa etapa é fundamental para a identificação presuntiva do fungo.

Inativou-se a esporulação adicionando $1 \mathrm{ml}$ de formol ao algodão e vedando a placa com fita adesiva durante $24 \mathrm{~h}$ à $48 \mathrm{~h}$ no oitavo dia de incubação. O vapor de formol, além de inativar o fungo, auxiliou na fixação das estruturas microscópicas. Após, retirou-se a lamínula com auxílio de uma pinça, uma vez que nela estavam aderidas as hifas e esporos do fungo. Pingou-se uma gota de corante azul de lactofenol-algodão e montou-se sobre uma lâmina para visualizar 
os esporos. Observou-se em microscópio ótico Coleman NLCD 120 ® com objetiva de 10, 20 ou 40 X, o tipo e cor da hifa, forma, disposição e formação de esporos e, em seguida, fotografadas. Nessa fase foram observadas as estruturas reprodutivas ou outras estruturas fúngicas (Lacaz,1998).

Para a identificação dos fungos filamentosos foi realizada uma análise descritiva das características morfológicas dos cultivos tendo em vista os seguintes aspectos: textura, topografia, superfície, cor da colônia, pigmento, cor do pigmento, tempo de crescimento e diâmetro da colônia, estruturas do micélio reprodutivo, presença de macroconídeos ou microconídeos, ascocarpos, picnídios, conidióforos e uma classificação foi utilizada para identificação das espécies dos gêneros fúngicos isolados (Brasil, 2012; Hoog et al, 2000).

Para a identificação das contaminações fúngicas das plantas e ambiente foram analisadas as colônias encontradas em cada placa.

Os procedimentos de análise dos dados das culturas foram realizados no departamento de microbiologia do campus de Frutal da Universidade do Estado de Minas Gerais.

\subsection{Análise estatística dos resultados}

Foram feitas as análises descritivas de todas as variáveis utilizadas no estudo. As variáveis contínuas foram apresentadas em relação a seus valores de tendência central e de dispersão, e as variáveis categóricas como valores absolutos e relativos.

Foram calculadas as incidências de fungos filamentosos na mucosa oral nos diferentes períodos de tempo definidos no estudo e para o período todo de trabalho nos três grupos de trabalhadores.

Para testar as diferenças nas variáveis contínuas entre os três grupos de trabalhadores foi utilizado o teste de Kruskal-Wallis. Para testar a associação entre as variáveis categóricas foram utilizados os testes do qui-quadrado de Pearson ou o teste exato de Fisher. 
Para investigar fatores de risco ou de proteção para infecção fúngica na mucosa oral nos três grupos de trabalhadores rurais utilizamos modelos de regressão logística em modelos univariados e múltiplos (Hosmer et al., 2013; Evanschitzky et al., 2006).

Para todos os testes foi adotada a significância estatística de 5\%.

As análises foram realizadas no pacote estatístico Statistical Package for Social Sciences -SPSS, versão 15.

\subsection{Orçamento e recursos:}

Os gastos com a pesquisa foram por conta da pesquisadora, sem ônus às instituições ou participantes do projeto.

Este estudo foi aprovado pelo Comitê de Ética em Pesquisa da Faculdade de Medicina da Universidade de São Paulo, de acordo com a Lei 196 de outubro de 1996, sob o número №:200/11 (ANEXO D). 


\section{RESULTADOS}

\subsection{Condições Climáticas}

Em relação às condições climáticas na primeira fase da coleta de dados denominada (to), a velocidade do vento variou de 2 a $3 \mathrm{~km} / \mathrm{h}$ sentido noroeste, com uma pressão atmosférica em torno de $1019 \mathrm{~Pa}$ e a umidade relativa do ar em torno de $33 \%$. A temperatura atmosférica variou de $30^{\circ} \mathrm{C}$ a $34^{\circ} \mathrm{C}$, média de $32^{\circ} \mathrm{C}$.

$\mathrm{Na}$ fase ( $\left.\mathrm{t}_{1}\right)$, as condições climáticas se mantiveram com uma velocidade do vento em torno de $3 \mathrm{~km} / \mathrm{h}$ sentido sudeste, pressão atmosférica de $1020 \mathrm{~Pa}$ e umidade relativa do ar em $15 \%$. A temperatura variou de $22^{\circ} \mathrm{C}$ a $27^{\circ} \mathrm{C}$, média de $23,5^{\circ} \mathrm{C}$.

$\mathrm{Na}$ fase ( $\mathrm{t}_{2}$ ), obtivemos velocidade do ar de $10 \mathrm{~km} / \mathrm{h}$ sentido noroeste, pressão atmosférica de $1017 \mathrm{~Pa}$ e umidade relativa do ar em $60 \%$. A temperatura variou de $20^{\circ} \mathrm{C}$ a $25^{\circ} \mathrm{C}$, média de $22,5^{\circ} \mathrm{C}$.

\subsection{Características sociodemográficas}

As características sociodemográficas dos participantes do estudo podem ser analisadas através da Tabela 1. 
Tabela 1 - Análise descritiva das características demográficas e renda dos trabalhadores rurais.

\begin{tabular}{llll}
\hline Variavéis & \multicolumn{3}{c}{ Grupo de Trabalhadores Rurais } \\
\cline { 2 - 4 } & Cana-de-açúcar & Laranja & Abacaxi \\
\hline Idade (anos) - média + DP & $27.73 \pm 3.75$ & $27.50 \pm 3.14$ & $30.83 \pm 5.60^{1,2}$ \\
Sexo Masc.- N (\%) & $58(96.7)$ & $44(73.3)$ & $52(86.7)$ \\
Raça - N (\%) & & & \\
Caucasianos & $17(28.3)$ & $25(41.7)$ & $32(53.3)$ \\
Afro-descendentes & $43(71,7)$ & $35(58.3)$ & $18(30.0)$ \\
Orientais & 0 & 0 & $10(16.7)$ \\
Renda Mensal (USD) - média & 850 & 800 & 900 \\
Tabagistas - N (\%) & $7(11,7)$ & $8(13,3)$ & $22(36,7)$ \\
Etilistas - N (\%) & $12(20,0)$ & $15(25,0)$ & $10(16,7)$ \\
\hline
\end{tabular}

Teste Kruskal-Walis na cana-de-açúcar e abacaxi com $p>0,05 ; 2$ - Teste Kruskal-Walis na laranja e abacaxi com $p>0,05$.

Podemos observar que os trabalhadores da cana e da laranja, na média, são um pouco mais jovens em relação aos trabalhadores do abacaxi. Quanto ao sexo nos três grupos, mais de três quartos dos trabalhadores eram do sexo masculino, sendo que o predomínio de homens ocorreu de uma forma mais evidente no grupo de trabalhadores da cana-de-açúcar. Em relação a raça, houve um predomínio de trabalhadores afrodescendentes nas culturas de cana e de laranja quando comparados ao abacaxi e, nesta cultura, houve um predomínio de caucasianos. Trabalhadores de origem oriental foram detectados apenas na cultura de abacaxi.

Quanto à renda, os trabalhadores de abacaxi recebem salários mais elevados do que os outros dois grupos.

O percentual de tabagismo foi mais elevado entre os trabalhadores de abacaxi e menos elevado na cana-de-açúcar. O mesmo ocorreu com a variável etilismo. Não houve diferença em relação à ingestão de álcool (teste de KruskalWallis $p=0,06$ ) e tabagismo (Kruskal-Wallis $p=0,54$ ) entre os três grupos. 


\subsection{Contaminações ambientais}

Em relação à contaminação do meio ambiente, tanto na planta quanto no ar, encontramos um maior índice de placas de Petri contaminadas nas plantações de abacaxi e cana-de-açúcar, respectivamente. Esta contaminação pode ser avaliada na figura 12 .

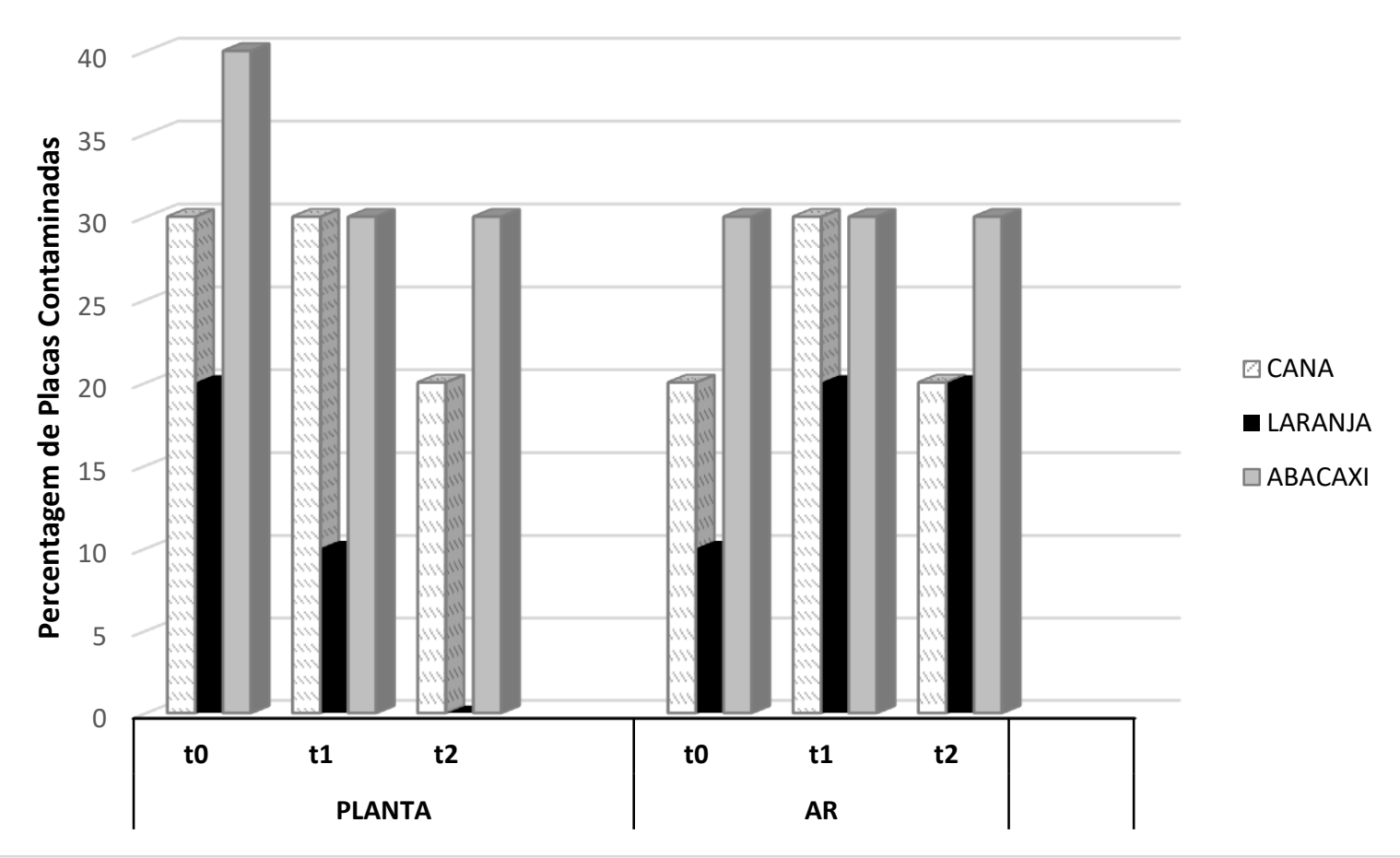

Figura 12 - Percentagem de placas de Petri contaminadas nos tempos de estudo definidos nesta pesquisa (10 placas em cada campo por período de tempo).

Em relação aos fungos encontrados nas plantas no meio ambiente como contaminantes, descritos na figura 13 , observamos um predominio de $F$. subglutians na cultura de cana-de-açúcar e de $F$. moniliforme nas culturas de laranja e de abacaxi nos períodos abrangidos por esta pesquisa. Constatou-se a presença de Puccinia melanocephala somente nos campos de cana-deaçúcar. Nestes campos, no tempo (to), três placas apresentaram contaminação por dois fungos diferentes. Já em ( $\left.\mathrm{t}_{1}\right)$, houve uma placa contaminada e, em ( $\left.\mathrm{t}_{2}\right)$, duas placas. Não foram encontrados fungos contaminantes das plantas na cultura da laranja no tempo ( $\mathrm{t}_{2}$ ). Em relação à contaminação pelo ar, nos campos 
de cana-de-açúcar, uma placa apresentou, nos tempos ( $\left.\mathrm{t}_{1}\right)$ e ( $\left.\mathrm{t}_{2}\right)$, os três tipos de fungos relacionados. Na contaminação do abacaxi, em (to) e (t 2 ) uma placa apresentou dois tipos de fungos.

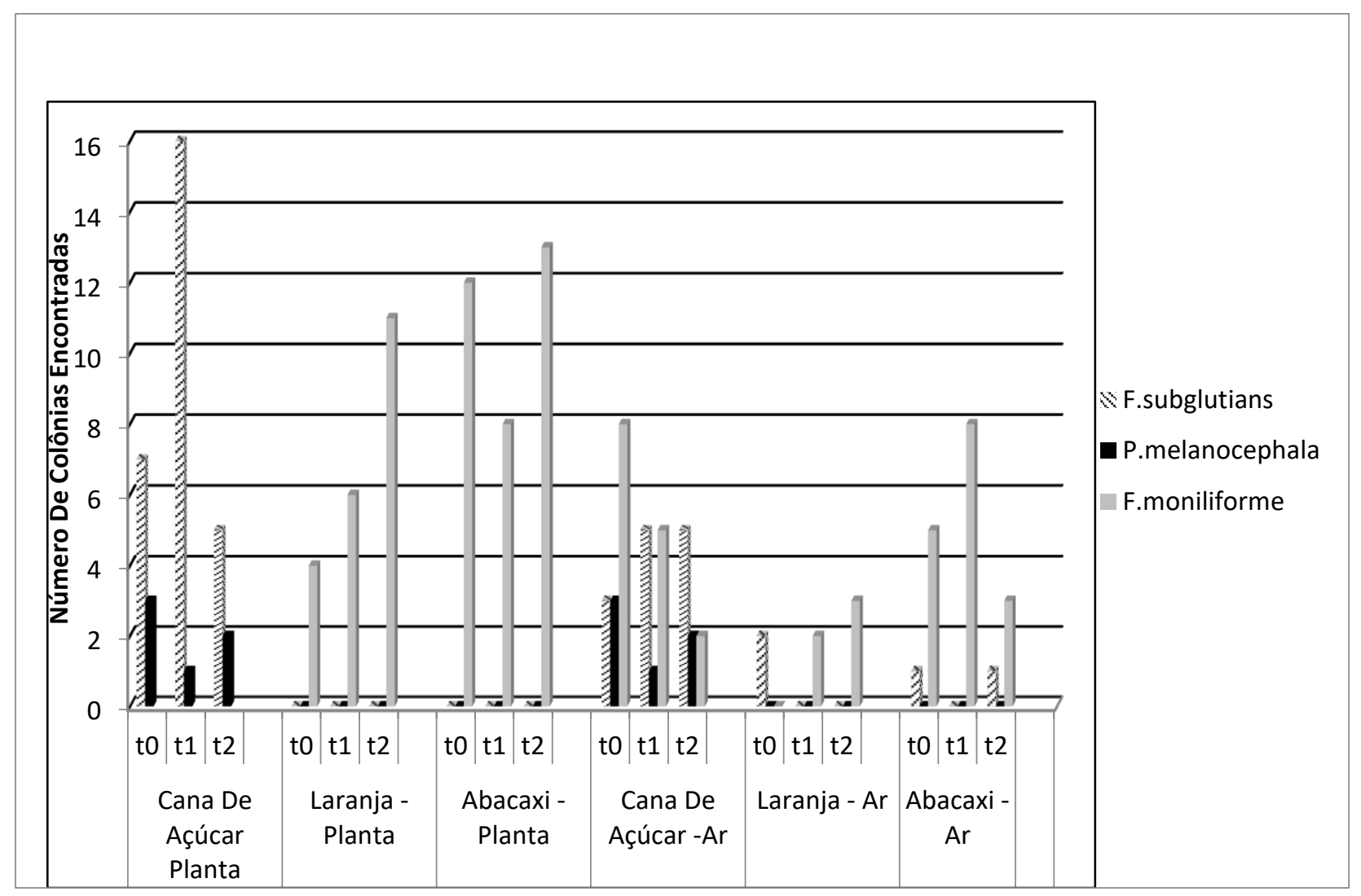

Figura 13 - Número de colônias encontradas, como contaminantes nos três tempos de analise nas culturas e no meio ambiente.

\subsection{Contaminação nos trabalhadores rurais}

A figura 14 mostra a contaminação fúngica nos trabalhadores das três culturas analisadas. A contaminação nos trabalhadores das três culturas ocorreu na segunda fase da pesquisa, no momento (t $\left.t_{1}\right)$. 


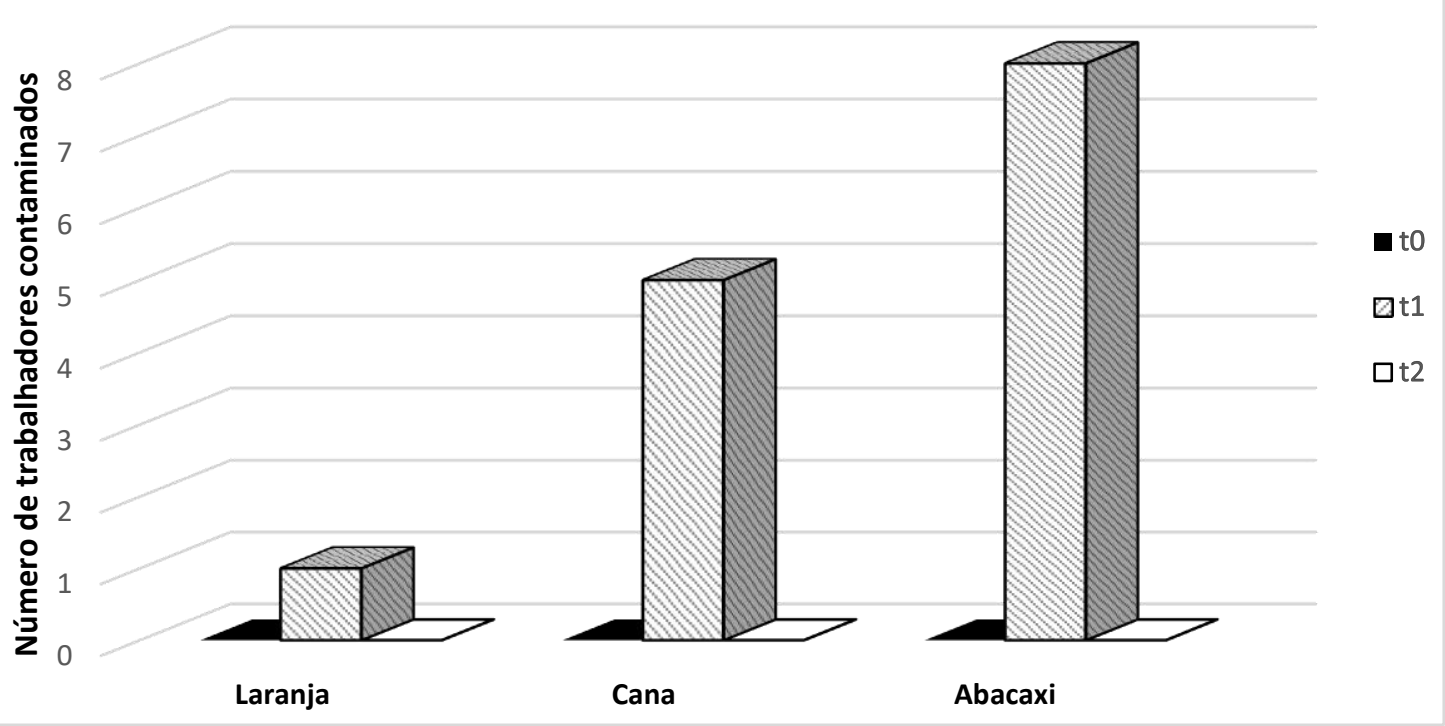

Figura 14 - Número de trabalhadores que apresentaram contaminação fúngica nos referentes tempos de observação do estudo.

Do corte de laranjas 1,6\% $(\mathrm{N}=1)$ foram contaminados por $F$. subglutinans.Em relação à cana-de-açúcar, $8,3 \%(\mathrm{~N}=5)$ dos trabalhadores demonstraram-se contaminados, sendo $5 \%(\mathrm{~N}=3)$ por $A$. niger e 3,3\%(N=2) por F. moniliforme. Os dois voluntários contaminados pelo $A$. niger apresentaram contaminação concomitante com $C$. albicans, no momento $\left(\mathrm{t}_{1}\right)$. Dentre os sessenta analisados das plantações de abacaxis, 13,3\% (N=8) foram contaminados com F. subglutinans. As características do Aspergillus niger podem ser observadas nas figuras 14, 15, 16 e 17, onde se verifica a presença de uma colonia filamentosa, granulosa de cor escura (que remete à borra de café) e reverso castanho. 


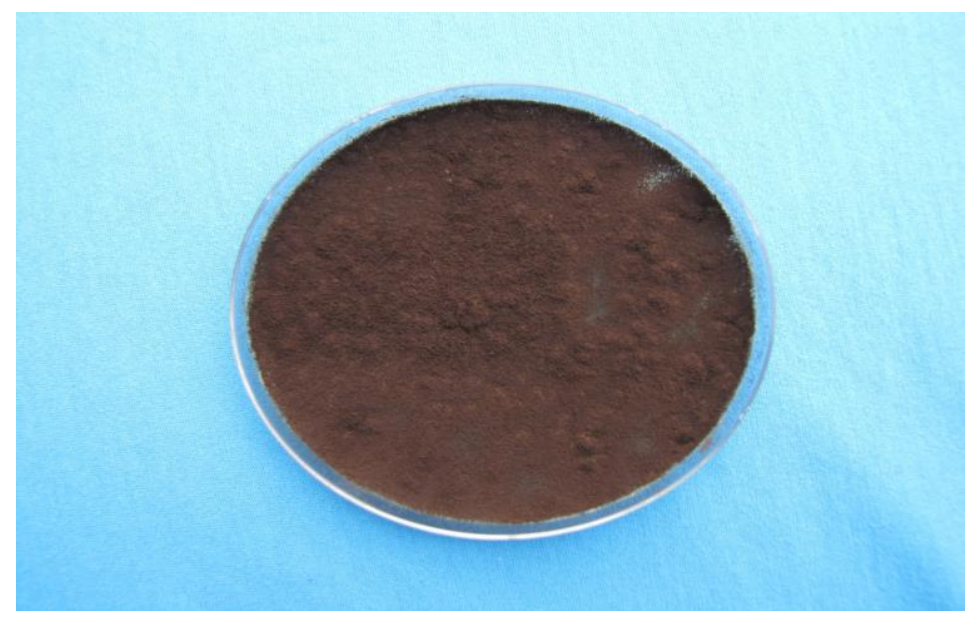

Figura 15 - Placa com Aspergillus niger, após repique.

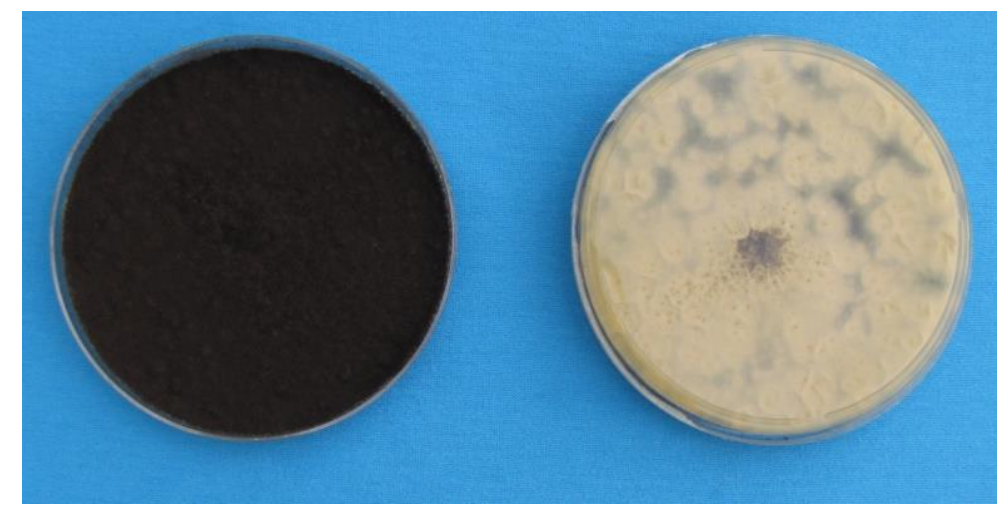

Figura 16 - Placas com Frente e Verso de A. niger.

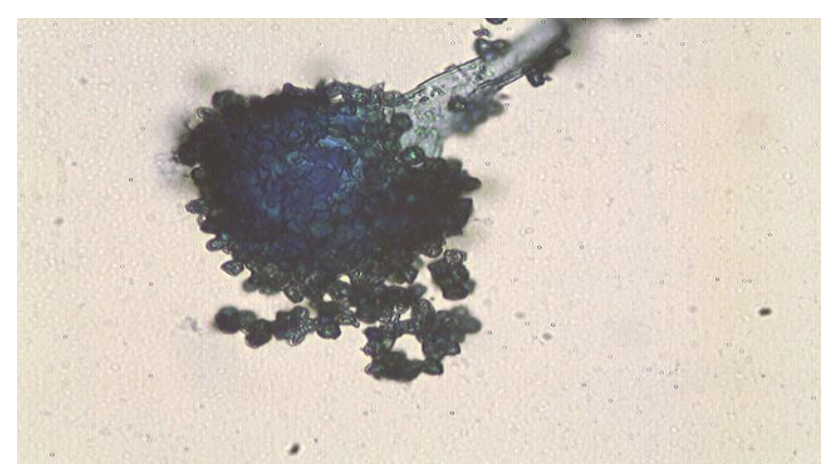

Figura 17 - Aspergillus niger (X100 LPCB: Nikon) 


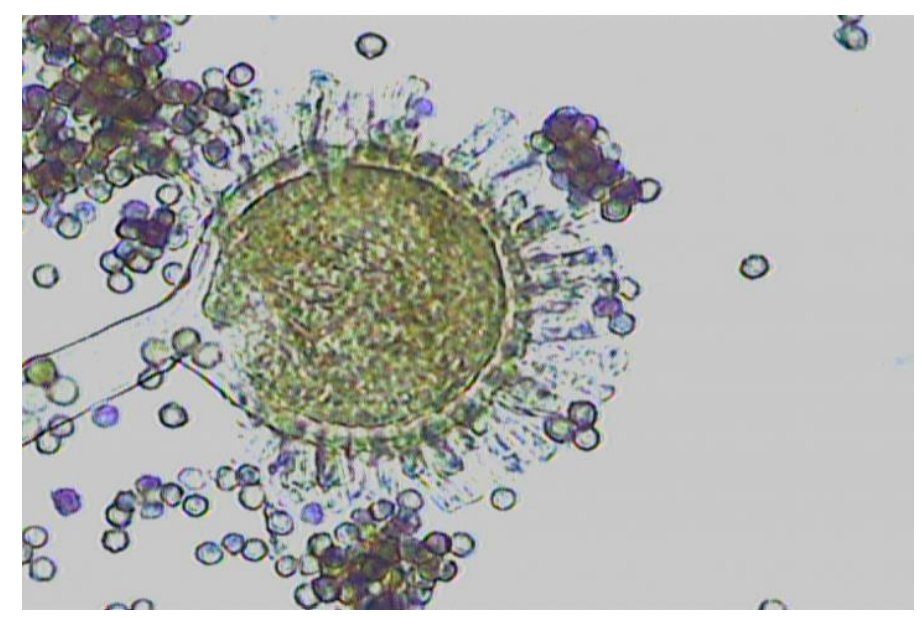

Figura 18 - Aspergillus niger (X400 LPCB: Nikon)

\subsubsection{Riscos de contaminação nos trabalhadores rurais}

Foram avaliados os riscos de contaminação em trabalhadores das três culturas definidas neste estudo. A tabela 2 apresenta resultados de regressões logísticas univariadas para investigar fatores de risco para infecção fúngica da mucosa oral. $\mathrm{O}$ ato de trabalhar na cultura do abacaxi se mostra um destes fatores de risco, se levadas em consideração as atividades nas culturas da cana e da laranja. Nenhuma outra característica demográfica foi considerada fator de risco ou proteção estatisticamente significante. 
Tabela 2 - Intervalos de confiança de odds ratio e 95\% para variáveis incluídas nos modelos individuais para investigar fatores de risco para infecção fúngica da mucosa oral.

\begin{tabular}{lcc}
\hline \multicolumn{1}{c}{ Variáveis } & OR & 95\% Cl \\
\hline $\begin{array}{l}\text { Grupos de Idade } \\
20-30 \text { anos } \\
>30 \text { anos }\end{array}$ & 1 & - \\
& 0,65 & $0,17-2,44$ \\
Tabagistas & & \\
Não & 1 & - \\
Sim & 1,8 & $0,46-7,0$ \\
& & \\
Etilistas & 1 & - \\
Não & 1,45 & $0,37-5,58$ \\
Sim & & \\
Renda Mensal & 1 & - \\
$\geq 851$ ( USD) & 2,2 & $0,27-17,50$ \\
$\leq 850$ (USD) & & \\
Grupo de Trabalhadores & 1 & - \\
Laranja & 5,36 & $0,61-47,36$ \\
Cana-de-açúcar & 9,08 & $1,10-75,02$ \\
Abacaxi & & \\
\hline
\end{tabular}




\section{DISCUSSÃO}

Este estudo demonstrou que trabalhar na cultura do abacaxi é um fator de risco para infecção fúngica na mucosa oral, se levadas em consideração as atividades na cultura da laranja. Além disso, houve contaminação fúngica na cultura de cana-de-açúcar no grupo de referência de pesquisa. Outros fatores como idade, taxa de ingestão de álcool, tabagismo, renda familiar e etnia não se mostraram fatores estatisticamente significativas na incidência da infecção fúngica filamentosa.

O aumento da taxa de infecção por fungos no começo do século $X X I$, que apresenta como variantes a região geográfica e aspectos demográficos, aliado a fatores de risco subjacentes ao ambiente de trabalho e às práticas médicas locais (Faria-Ramos et al., 2014; Centers for Disease Control and Prevention, 2014g), torna a pesquisa de contaminação fúngica em trabalhadores rurais cada vez mais necessária.

Essa, é a primeira pesquisa no mundo a estudar a contaminação fúngica por fungos filamentosos em mucosa oral de trabalhadores rurais. Levando-se em conta as dificuldades de trabalho e escassas condições de saúde, que envolvem, desde o horário de trabalho em turnos até a relação com o empregador, esse estudo traz informações importantes e inéditas que soma a outros que, investigando outras condições de saúde na população, procuram avaliar a situação do trabalhador rural de forma mais completa.

A saúde ocupacional é a procura do equilíbrio do homem no seu ambiente de trabalho (Santos e Leite, 2012) e, sabendo-se que no Brasil o contingente de trabalhadores rurais em condições de trabalho precárias é bastante expressivo (Abreu et al., 2014; Rosa e Navarro, 2014), esse equilíbrio é uma demanda que já deveria estar estabelecida há tempos.

O índice de contaminação na amostragem de trabalhadores desta pesquisa explica-se pelo fato de que quem vai ao ambulatório de dermatologia já apresenta uma queixa prévia, mas se realizada uma seleção aleatória, na qual 
os participantes não possuam ainda alguma patologia clinicamente diagnosticada, provavelmente seria difícil que fossem avaliados no ambulatório de dermatologia. Esse fato determina uma diferença notável entre a população de consultório e os participantes do estudo.

Um estudo longitudinal de incidência numa população desprovida de estudos epidemiológicos, em vez de um estudo transversal, permite uma melhor investigação dos fatores de risco. Talvez, se houvesse a oportunidade de incluir um maior número de participantes, a investigação sobre outros possíveis fatores de risco para infecção fúngica em mucosa oral destes trabalhadores seria mais abrangente.

A contaminação fúngica nos trabalhadores das três culturas ocorreu no segundo período da pesquisa $\left(\mathrm{t}_{1}\right)$ e teve como agente mais frequente o fungo do gênero Fusarium.

Nas atividades laborais deste estudo, a contaminação direta por fungos filamentosos em mucosa oral pode acontecer através de dois fatores: a primeira refere-se a postura ergométrica dos trabalhadores e a segunda aos hábitos relacionados às atividades laborais.

No plantio do abacaxi os riscos ocupacionais estão presentes em todas as etapas do processo produtivo e raramente observa-se algum tipo de Equipamento de Proteção Individual (EPI). Por tratar-se de um vegetal herbáceo, quase acaule (Giro,2011), seu plantio é realizado em posição inclinada ou agachada (Gonzaga et al., 2014), fazendo com que a região oral fique bem mais próxima da planta e do solo, permitindo a maior inalação de poeira e de fungos. Além disto, os trabalhadores são estimulados a não ter vínculo empregatício, o que interfere no fornecimento de EPI (Fundacentro, 2014), o que minimizaria este contato.

Os trabalhadores da cana-de-açúcar também apresentaram uma contaminação expressiva quando comparados ao grupo do controle de laranjas. Para essa atividade laboral, ser jovem e ser migrante nordestino são atributos bem valorizados, tornando-os potencialmente mais produtivos por se tratarem de pessoas simples e com baixa condição socioeconômica. Estes atributos as 
tornam pessoas habituadas a lidar com trabalhos pesados e a viver em situações adversas, tornando-as completamente voltadas para o trabalho (Rosa e Navarro, 2014). No manuseio da cana-de-açúcar, a proximidade das vias aéreas é menor, quando comparado ao do trabalho no abacaxi, pois muitos usam um pano enrolado na face, tampando o nariz e a boca, além do fato dos pés de cana-deaçúcar atingirem uma altura alta a partir do caule (entre 3 e 6 metros de altura) (Embrapa, 2012), sendo a postura do cortador, assim, sempre inclinada.

Quanto aos trabalhadores da laranja, apenas um foi contaminado. $\mathrm{Na}$ avaliação dos campos, observa-se que as mudas já medem 1,5 metro de altura e 3 centímetros de diâmetro, e os pés adultos atingem cerca de 8 metros de altura (Embrapa, 2009). Os trabalhadores da laranja normalmente utilizam escadas ou tesouras adaptadas para uso manual e sua posição ergométrica é ereta, devido à altura do citrus. Estas práticas, juntamente com o uso de anteparos no nariz e na boca como proteção (Pranav e Patel, 2016; Costa e Camarotto, 2012), minimizam o contato da região oral com o solo e com as plantas.

Os trabalhadores rurais também têm o hábito de colocar gravetos ou varas de grama na boca durante o seu trabalho. As pequenas lesões causadas por este hábito funcionam como porta de entrada para diversas doenças (Brás et al., 2015; Marin et al., 2014; Santo, 2008).

Além disto, a contaminação fúngica dos trabalhadores rurais tem ligação com os descumprimentos das normas de higiene (NR31), associadas à alimentação e a funções fisiológicas, que são realizadas no próprio local de trabalho. Esse quadro não condiz com a modernização dos campos; esperar-seia banheiros químicos e locais apropriados para alimentação. Essa ausência de condições sanitárias minimamente adequadas determina propriedades degradantes de emprego para o trabalhador do campo (Luz et al., 2014). Essas situações são observadas nas três culturas analisadas, principalmente nas de cana-de-açúcar e abacaxi, criando um ambiente de risco maior para trabalhadores dessas atividades agrícolas. 
Diversos estudos sobre a exposição ocupacional a fungos filamentos e doenças do trato respiratório foram desenvolvidos, como os realizados com agricultores (Żukiewicz-Sobczak et al., 2013; Adhikari et al.); trabalhadores de ambiente úmido (SahinKaya e Parlak, 2005; Lugauskas e Kristaponis - Sveistyte, 2004; DutkiewiczKrysinska-Traczyk e Pražmo, 2001) e trabalhadores de refinarias de açúcar (Jensen, Todd e Hart, 1993). No entanto, nenhum deles investigou o contágio da região oral.

A pesquisa científica que mais se aproxima ao presente estudo foi realizada por Martins-Diniz et al. (2005), analisando infecção fúngica filamentosa em orofaringe em trabalhadores que atuavam em unidades de terapia intensiva e centros cirúrgicos. Coincidentemente, a incidência de contaminação fúngica em orofaringe foi semelhante à encontrada neste estudo. Ademais, esses autores obtiveram com mais frequência o gênero Cladosporium. Ambientes laborais distintos apresentam características peculiares, que podem favorecer a infestação fúngica filamentosa dos trabalhadores que os frequentam. Identificar estes fatores e combatê-los deve fazer parte das rotinas de vigilância laboral.

A região oral é a via de acesso ao sistema digestivo, auxiliar na respiração e na fonação. Essa localização favorece a absorção e a excreção de substâncias assimiláveis ao organismo (de Carli et al., 2012). É um sítio anatômico que apresenta um grande número de outras afecções, o que dificulta o diagnóstico de contaminação fúngica filamentosa. Entre essas doenças, podemos citar o carcinoma de células escamosas, as leucoplasias, as candidíases puras e a sífilis secundária (Bertoni, 2010).

As doenças bucais decorrentes do ambiente laboral podem ser lesões que se manifestam em função de uma doença sistêmica ou causadas diretamente pelos agentes ambientais sobre as estruturas bucais (Hiroishi et al., 2012; de Carli et al., 2012). A localização anatômica, associada à higiene oral deficiente observada nas atividades laborais rurais, contribui para o aumento da concentração de patógenos na saliva (da Cruz et al., 2014; Amaral, Cortes e Ramôa, 2009). Essa colonização é contínua na região de orofaringe e apresenta, praticamente, metade de toda a microbiota presente no corpo humano, o que pode determinar infecções locais e à distância (da Cruz et al., 2014; Gaetti- 
Jardim et al., 2012; Barbosa et al., 2010; El-Solh et al., 2004; Patterson et al., 2000). Quando há um desequilíbrio na interação hospedeiro-patógeno em que os mecanismos de proteção do organismo são vencidos pela virulência do agente (Gaetti-Jardim et al., 2012; Patterson et al., 2000), há um aumento do risco de doenças, inclusive quando se trata de infecções fúngicas, reafirmando a importância dos resultados desta pesquisa.

Os organismos dos microbiomas da cavidade oral compreendem uma comunidade complexa e são componentes críticos do binômio saúde-doença. Apesar do componente fúngico fazer parte da microbiota oral, eles não foram bem identificados ainda (Ghannoum et al., 2010). A quebra do equilíbrio biológico desta região tem sido considerada o fator desencadeante ou mantenedor de diversas doenças bucais (Jenkinson e Lamont, 2005).

O desenvolvimento de fungos filamentosos está relacionado aos fatores ambientais para seu desenvolvimento. A temperatura é o fator ambiental que mais interfere no crescimento dos fungos e é considerada ótima para 0 crescimento quando se encontra entre $20^{\circ} \mathrm{C}$ e $30^{\circ} \mathrm{C}$, inclusive para produção de substâncias, como as lipases (Colla et al., 2013; Nazario, 1979). Ela influencia a reprodução micelial, a esporulação, a germinação de conídios e também na coloração das colônias, podendo ser utilizada como parâmetro para diferenciação de espécies (Maia et al., 2011). Os esporos podem ser levados a grandes distâncias pelos ventos, quando a via de dispersão é o ar atmosférico (Gambale, 1983). Essa facilidade de distribuição ocasiona a dispersão desta aeromicobiota em uma variedade de substratos, como os solos, plantas etc.

As temperaturas médias encontradas nos tempos desta pesquisa foram $32^{\circ} \mathrm{C}$ para (to), $24,5^{\circ} \mathrm{C}$ para ( $\left.\mathrm{t}_{1}\right)$ e $22,5^{\circ} \mathrm{C}$ para ( $\mathrm{t}_{2}$ ). Além disso, Pereira et al. (2013) observaram que cada localidade apresenta diferentes variações fúngicas, influenciadas por diversos fatores, inclusive a localização geográfica, sazonalidade e velocidade do vento (Menezes et al., 2004), o que amplia as condições favoráveis ao desenvolvimento dos fungos filamentosos.

O gênero Fusarium apresenta faixa de temperatura ótima para o seu crescimento entre $20^{\circ} \mathrm{C}$ e $25^{\circ} \mathrm{C}$, mas pode se desenvolver em temperaturas 
variando de $5^{\circ} \mathrm{C}$ a $40^{\circ} \mathrm{C}$ (Le Bars et al., 1994; Pitt e Hocking, 1997). O teor de umidade nos substratos propicia um microclima adequado ao desenvolvimento fúngico (Diniz, 2002), sendo o ideal de $25 \%$ a $30 \%$, principalmente para os gêneros Fusarium e Aspergilus. Para os períodos estudados nesta pesquisa, foram encontrados os seguintes teores de umidade: $33 \% \mathrm{em}\left(\mathrm{t}_{0}\right), 25 \% \mathrm{em}\left(\mathrm{t}_{1}\right) \mathrm{e}$ $60 \%$ em ( $\mathrm{t}_{2}$ ). Estes resultados corroboram com os encontrados nesta pesquisa para o desenvolvimento dos fungos analisados.

Os fungos filamentosos são encontrados em todos os biossistemas. As culturas de cana-de-açúcar, abacaxi e laranja apresentam como contaminantes algumas espécies de fungos, que podem provocar doenças em humanos. $O$ gênero fúngico mais comum encontrado tanto nas plantas quanto no ambiente foi o Fusarium e as mesmas espécies encontradas nos trabalhos de Vieira et al. (1989) e Olson (1969).

Culturas como a cana-de-açúcar e o abacaxi podem causar perdas por este gênero, que variam de $30 \%$ a $50 \%$ de toda a lavoura, mesmo com o desenvolvimento de mudas mais resistentes e dos meios de pulverização contínua (Rocha et al., 2016; Caetano et al., 2015; Nogueira et al., 2014). As espécies encontradas no meio ambiente e nas plantas nesta pesquisa concretizam essas afirmações.

Em relação ao padrão sociodemográfico, o trabalho rural apresenta uma característica importante: a de não ser contínuo, sistemático e linear, como é o trabalho nas fábricas (Tessari, 2011). Dependente das condições meteorológicas, das condições de mercado e do ciclo das plantas, o trabalho rural tem apresentado contínua e forte redução (Tessari, 2015; Dieese, 2013), sem que haja alteração nas características sociodemográficas em relação ao sexo, idade e cor. Essas características estão ligadas ao início da colonização, com o emprego da mão de obra escrava, onde a atividade rural era desenvolvida, principalmente, por homens, e mantém-se por muitas décadas, tendo sido retratado por diferentes autores nos últimos 50 anos (Pinto et al., 2012; Sabino et al., 2012; Danfré, et al., 2007; Olson, 1969). Mesmo com o surgimento do "novo rural brasileiro", formado pelo agronegócio e pela agricultura familiar, estas características sofreram poucas modificações (Camacho, 2014). Os achados 
nesta pesquisa confirmam essa manutenção destas características com 0 predomínio de homens, faiodérmicos, em idade próxima dos 30 anos, nas três culturas analisadas.

Quanto à renda, em um estudo caso-controle realizado por Prasad et al. (2014) com 150 trabalhadores rurais imunocompetentes, na Índia, observou-se que a renda mensal, inferior a 5000 rúpias nacionais indianas $(2,75$ a 77,18 dólares americanos), se mostrou fator de risco para otite filamentosa, quando comparada à renda mensal igual ou superior a 20000 rúpias nacionais indianas (308,70 dólares americanos). No presente estudo, a renda dos trabalhadores se mostrou muito maior do que a dos trabalhadores indianos avaliados no trabalho acima mencionado. Mesmo assim, apesar da ausência de significância estatística, estar no grupo de menor renda se mostrou um potencial fator de risco para infecção fúngica em orofaringe.

Evidências clínico-epidemiológicas têm apontado que fatores ou hábitos associados com o tabagismo e o consumo de álcool podem favorecer o surgimento de contaminação fúngica por ação deletéria no sistema imunológico (Magalhões, 2013). Em relação ao tabagismo, os compostos químicos encontrados no tabaco contribuem, de maneira inquestionável, para o desenvolvimento de alterações celulares em orofaringe, diminuindo a ação combativa de infecções bacterianas e fúngicas (Lee, Taneja e Vassallo, 2012). A ingestão de álcool, bem como o tabagismo, diminui a atividade mucociliar, podendo, dessa forma, afetar a mucosa (Parise-Fortes et al., 2011), propiciando um maior risco de contaminação fúngica filamentosa nos trabalhadores rurais. Nesta pesquisa não houve relação estatística quanto a esses hábitos.

Entre as infecções fúngicas não-filamentosas relacionadas ao tabaco e à ingestão de álcool está a candidíase, que é causada por Candida sp, sendo amplamente divulgada na literatura científica (Simões, Fonseca e Figueiral, 2013). Além da Candida sp, outro fungo que merece destaque é Paracoccidioides brasiliensis. Ele causa a principal micose sistêmica no Brasil, com maior frequência nas regiões sul, sudeste e centro-oeste, sendo as que mais se aproximam, em suas características, dos fungos filamentosos (Martinez, 2015; Magalhões, 2013). É um fungo termo-dimórfico e se apresenta sob duas 
formas: micélio e levedura. A forma micelial é encontrada na natureza à temperatura de $18^{\circ} \mathrm{C}$ a $25^{\circ} \mathrm{C}$ e é produtora de esporos ou conídios infectantes que, quando inalados pelos hospedeiros susceptíveis, podem se transformar em células leveduriformes em seus tecidos (Lacaz et al., 2002). Esse processo morfogenético é reversível, implicando na capacidade de adaptação às mudanças das condições ambientais e permitindo a sobrevivência do fungo e sua invasão aos tecidos do hospedeiro (de Macedo et al., 2016; Restrepo, 2012; San-Blas, Burger, 2011). O causador da paracoccidioidomicose é conhecido como a causa mais comum de lesão em orofaringe por fungos na América do Sul (Goes et al., 2014; Azenha et al., 2012).

O gênero encontrado com maior frequência neste estudo, o Fusarium, pode ser encontrado nos solos, plantas e no ar, sobrevivendo por meses nestes ambientes (Dos Santos e Wagner, 2014; Stanzani et al., 2007; Dignani e Anaissie, 2004). Sua classificação taxonômica apresenta espécies muito próximas, com um papel importante na estabilidade da comunidade microbiana (Peleg, 2010), como pode ser observado entre o F. subglutians e F. moniliforme. As metodologias genômicas para identificar as espécies e comunidades de fungos ainda são muito restritas e têm sido limitadas quando comparadas com aquelas que estão disponíveis para bactérias (Graça, 2015; Findeley et al, 2013; Dollive, 2012). Nesta pesquisa, optou-se em manter essa divisão pois, apesar de alguns autores os considerarem como variantes, eles apresentam o mesmo potencial de patogenicidade (Querales, 2010).

No ser humano, as espécies de Fusarium podem causar infecções superficiais, invasivas locais e disseminadas (Perini et al., 2013), sendo que os casos mais graves estão relacionados aos indivíduos imuno-incompetentes (Pemán e Salavert, 2014). A importância clinica desse gênero também se associa à produção de micotoxinas, principalmente as fumonisinas, resultado secundário do metabolismo do F. moniliforme (Graça, 2015). Mas é válido ressaltar que o gênero Fusarium pode estar presente na região da orofaringe de indivíduos saudáveis, o que foi comprovado pelo estudo de Ghannoum et al (2010), onde encontraram cerca de $30 \% \quad(\mathrm{~N}=20)$ de seus analisados contaminados por este gênero. 
Quanto ao risco ocupacional de contaminação fungica, a agricultura é o setor da economia com o maior risco de doença de pele e mucosas, cerca de 20\% delas causadas por fungos (Żukiewicz-Sobczak, Badora, Zwoliński, 2013). Estudos epidemiológicos para levantar causas de ceratites oculares por fungos filamentosos demonstram que, nos trabalhadores rurais, a contaminação ocular é muito mais frequente do que em outras atividades laborais (Comarella et al., 2015).

A grande maioria das micoses são de origem oportunista, relacionadas à imunodeficiência (Barroso et al., 2014; Goes et al., 2014) e que iniciam-se ao nível do trato respiratório ou da pele e mucosas (Huprikar e Shoham, 2013). No que se refere à contaminação cutaneomucosa, as infeções fúngicas estão frequentemente associadas a pessoas com atividade profissional ligada ao manuseio da terra e à pecuária (Brás et al., 2015). Ela ocorre através de pequenas lesões provocadas por material agressivo para a pele e mucosas, como farpas e espinhos, colocando os trabalhadores do meio agrícola com maior risco de contaminação através destas lesões (Brás et al., 2015). A infecção fúngica em humanos pode ser definida como "inerente a cada indivíduo", pois é dependente direta da condição clínica e da relação do indivíduo com o meio ambiente (Barroso et al., 2014), associado aos fatores socioeconômico, geográfico e climático (Marin et al., 2014).

O ambiente insalubre, decorrente de radiações solares, da presença de partículas no ar e de agentes infecciosos e parasitários (Hiroishil, et al 2012; Menegath e Fontana, 2010), além da falta de higiene e alimentação dos trabalhadores rurais no próprio local das culturas, levando ao descarte dos restos alimentares diretamente no solo, criam um ambiente propício ao crescimento fúngico no ambiente (Santos e Batista, 2015; Żukiewicz-Sobczak et al., 2013; Pfohl-Leszkowicze Manderville, 2007).

A infecção mais comum por Fusarium sp pode ser considerada aquela que acomete a pele e as mucosas. Nos indivíduos imunocompetentes, as lesões são normalmente localizadas e ocorrem por algum trauma (Nucci et al., 2013; Anaissie et al., 2009), podendo causar infecção superficial, invasiva ou disseminada (Shoham, 2013). 
O alto índice fúngico nas plantações pode ter uma possível explicação quando observada a situação dos fazendeiros das regiões sudeste e centrooeste do Brasil. O controle das pragas nas plantações, em sua grande maioria, é de responsabilidade do proprietário ou arrendatário da terra. Nas culturas do abacaxi, no Brasil, a fusariose causada por Fusarium moniliforme, é a principal doença (Palomino et al., 2015; De Souza et al., 2013), com perdas estimadas entre $50 \%$ e $100 \%$ dos frutos e em até $50 \%$ das mudas (Fernandes et al., 2015). O controle de fungos nas três culturas analisadas é um procedimento caro e pode chegar a 30\% do custo de produção (da Silva et al., 2015; Fundecitrus, 2014). Dos fungicidas usados para o combate desse fungo, estão registrados somente dois princípios ativos: o Paration metílico e o Etion, segundo o Ministério da Agricultura, Pecuária e Abastecimento (Brasil, 2014), no que esse refere ao abacaxi. Já para a cana-de-açúcar, os princípios ativos Azoxistrobina, Ciproconazol, Fluodioxonil, Metalaxil devem ser associados entre eles para que possam apresentar resultados satisfatórios no combate fúngico dos campos. Em relação à cultura da laranja, a substituição do fungicida Carbendazin pelo produto do grupo Estrobilurina tem ocorrido nos campos brasileiros desde 2009, o que tem encarecido as pulverizações preventivas (Fundecitrus, 2016). Esse custo, nas três culturas, gera falhas de ações preventivas, pois os agricultores preferem ter uma produtividade menor, diminuindo as irrigações de fungicidas nos campos agrícolas e aumentando sensivelmente o risco para a saúde do trabalhador (Mohanraj et al., 2002).

Especificamente na situação da laranja, é importante realçar que a retomada de uma prática antiga e importante de controle às pragas denominada poda (Azevedo et al., 2013) pelos citricultores brasileiros reduz sensivelmente a presença dos fungos nas plantas, principalmente aquelas que se desenvolvem no interior da copa (Santarosa, et al. 2013), o que pode justificar o baixo índice de contaminação nestas culturas (Laranjeiras, et al 2005). Isso reforça o índice de contaminação encontrada nos trabalhadores da laranja.

Neste estudo mostramos que os fungos presentes nos trabalhadores, eram os mesmos encontrados no local de trabalho. No entanto, ao contrário do gênero Fusarium, encontrado mais frequentemente nas lavouras analisadas, o 
Aspergillus niger não é um fungo comum a elas. Mesmo sendo amplamente encontrado nos biomas terrestres, não há relatos de doenças causadas por Aspergillus niger em gramíneas. Neste presente estudo, três trabalhadores da cana-de-açúcar apresentaram contaminação por este fungo, sendo dois deles com concomitância à infecção por $C$. albicans. As espécies de Candida e Aspergillus representam cerca de $70 \%$ das espécies que provocam infeções fúngicas em humanos (Robbins et al., 2011). O poder patogênico de Candida $s p$ é dependente não só de fatores do hospedeiro, mas também dos fatores de patogenicidade do fungo. Dentre as espécies de Candida que podem causar candidíase, a espécie Candida albicans é predominante, inclusive em orofaringe (Orasch et al., 2014; CDC, 2014g; Pfaller, Diekema, 2007). A presença de $C$. albicans não significa necessariamente que há imunossupressão no hospedeiro, pois foram isoladas leveduras da região oral de voluntários normais, utilizando uma metodologia semelhante à empregada nesta pesquisa (Barbosa et al., 2014; Simões et al., 2013). O Aspergillus niger, por sua vez, é considerado um agente emergente, capaz de se propagar de forma eficaz em diferentes ambientes (Meijer,et al, 2011), sendo um dos causadores da aspergilose em humanos e sua maioria é de origem oportunista (Afonso, 2015; Anaissie et al., 2009; Pfaller et al., 2007). Merece destaque a aspergilose cutânea-mucosa, em que o microrganismo entra no corpo através de uma fissura prévia, podendo evoluir para aspergilose invasiva (CDC, 2014j). Para a busca de uma possível explicação para esta contaminação, recorreu-se a Gomes et al. (2015) e Telles et al. (2011), que demonstraram que o ambiente da cana-de-açúcar é rico em celulose, hemicelulose e lenhina. Este meio rico nestas substâncias se mostraram um meio de cultura para fungos superior aos meios padrões, como ágar de dextrose de batata, ágar de dextrose de Sabouraud, e ágar de farinha de milho. Oito espécies de fungos, entre eles Aspergillus niger, Candida albicans e Fusarium sp, foram cultivados em meio de bagaço de cana concebendo um ambiente capaz de fornecer alimentação para os fungos, bem como evitar o crescimento de qualquer contaminante de bactérias. Além disto, esse meio aumenta a produção de esporos (Arushdeep e Umar, 2014). Observa-se, então, que o ambiente da lavoura com a presença da palha e bagaço da cana-de- 
açúcar é um meio propício ao crescimento fúngico no campo, inclusive para o $A$. Niger.

Durante a fase de manuseio da cana e da utilização do bagaço, há um aumento significativo de esporos de fungos na composição do ar, que podem ser levados a grandes distâncias (Freitas et al. 2012; Angelini et al., 2010; Singh, Alka Singh e Pandit, 1999). Devido à germinação do $A$. Niger, que é caracterizado por uma grande transição da transcrição, isto é, durante as primeiras duas horas após a inoculação (Leeuwen et al., 2013), a cana-deaçúcar se mostra um meio de cultura para diferentes tipos de fungos, como o Aspergillus niger, a Candida albicans e o Fusarium sp, causando um aumento do risco de infecção da orofaringe dos trabalhadores. Ou seja, a atividade laboral da cana-de-açúcar está inserida num meio de cultura natural para fungos.

A detecção de doenças em seus estágios iniciais pode afetar significativamente o prognóstico. Quanto mais cedo a intervenção terapêutica for efetuada, maiores as taxas de sobrevivência e recorrência dos pacientes. Apesar do risco de contágio biológico ser amplamente divulgado nos projetos de assistencia básica à saúde do trabalhador (Brasil, 2014), culturalmente as doenças de importância no trabalho rural estão associadas ao esforço físico e ao uso de agrotóxicos (Oliveira et al., 2013; Menegat e Fontana, 2010).

Os resultados deste estudo mostraram que as incidências de contaminação humana por fungos filamentosos nas culturas de abacaxi e canade-açúcar foram maiores do que as encontradas nos trabalhadores da cultura da laranja.

A atividade laboral agrícola propriamente dita envolve as atividades compostas por trabalhadores rurais responsáveis por tarefas que vão desde 0 plantio, passam pelo desenvolvimento da cultura e culminam com a colheita (Prado, 2011). Atualmente, quando se faz referência ao trabalho no campo, inclui-se também os operadores de máquinas diversas, responsáveis por atividades relacionadas ao trato do solo, fertilização, transporte, supervisão de campo, manutenção de equipamentos e colheita mecanizada (Prado, 2011). Mantendo essa linha de pensamento, os dados encontrados nesta pesquisa 
podem ser expandidos a outros setores das culturas analisadas, que, apesar de não participarem diretamente do contato com as plantas, estão de uma forma indireta envolvidas no trabalho agrícola, sendo potencialmente expostos aos mesmos fungos.

Deste modo, outras pesquisas poderiam ser desenvolvidas para que se possa mapear, de uma forma mais fidedigna, os riscos das atividades laborais rurais em relação à contaminação de orofaringe por fungos filamentosos.

Apesar dos trabalhadores contaminados não terem apresentado nenhuma manifestação clínica em consequência desta infecção, é importante ressaltar que uma avaliação adequada destes trabalhadores deve envolver também o exame das mucosas orais, na tentativa de controlar rapidamente estes quadros infecciosos. 


\section{CONCLUSÃO}

Podemos concluir que a participação dos trabalhadores rurais foi predominante de homens afrodescendentes nas culturas de cana e de laranja e homens caucasianos nas culturas de abacaxi.

Somente nas culturas do abacaxi observamos trabalhadores de origem oriental.

A idade e a condição socioeconômica dos trabalhadores das três culturas analisadas se mostraram praticamente as mesmas.

A contaminação dos trabalhadores das três culturas ocorreu na segunda fase do inquérito, no momento $\left(\mathrm{t}_{1}\right)$.

Houve maior incidência fúngica nos trabalhadores do abacaxi e cana-deaçúcar, quando comparados aos da laranja.

O gênero de fungos mais encontrados nos trabalhadores e nos campos das culturas analisadas foi o Fusarium.

Somente nos trabalhadores da cana-de-açúcar foi encontrado o A. niger (em três indivíduos), sendo que havia, em dois deles, concomitância com $C$. albicans.

O único fator de risco detectado foi o de trabalhar na cultura do abacaxi em relação a cultura de laranja.

A ingestão de bebida alcoólica, o tabagismo, a condição socioeconômica e a idade não se mostraram fatores de risco para contaminação por fungos filamentosos da região de orofaringe, nesta pesquisa. 


\section{CONSIDERAÇÕES FINAIS}

Os resultados deste estudo constituem um achado pioneiro, que evidenciou a contaminação fúngica filamentosa em orofaringe de trabalhadores rurais. As situações de risco, associadas à saúde do trabalhador rural, à alimentação deficiente, às condições sanitárias precárias e à deficiência dos serviços de saúde, promovem a presença grave de um complexo problema de saúde ocupacional.

Esse tema gera uma necessidade de se efetuar mais estudos. Os resultados possibilitam ampliar essas pesquisas para outras culturas, com intuito de criar métodos e desenvolver estratégias de saúde que diminuiriam a incidência de infeções fúngicas filamentosas nos trabalhadores rurais. 


\section{ANEXOS}

\section{ANEXO A}

\section{Vamos começar com perguntas sobre você}

FICHA CLÍNICA N. 음

Nome:

Endereço :

Telefone :

Cidade: De que Estado você é?

Sexo: $M() F()$ ldade: data nascimento :

\section{Hábitos:}

Fumante: ( ) sim () não

Quanto tempo? Quantos cigarros/dia?

Etilista: ( ) sim ( ) não Quanto tempo? Quantos copos por dia? Antes 30 dias?

Tem alguma doença?

Usa alguma medicação?

Teve alguma internação nestes últimos seis meses?

Há quanto tempo fez seu último tratamento dentário?

Mais de três meses ou menos

\section{Trabalho anterior}

Já trabalhou nos campos de cana-de-açúcar antes? Sim ou não

Se sim quanto tempo

Qual sua última ocupação?

\section{AVALIAÇÃO DERMATOLOGICA DA MUCOSA ORAL}

Exame bucal 
1.ALGUMA LESÃO APARENTE? ( ) SIM ( ) NÃO

Se sim descrever alterações 


\section{ANEXO B}

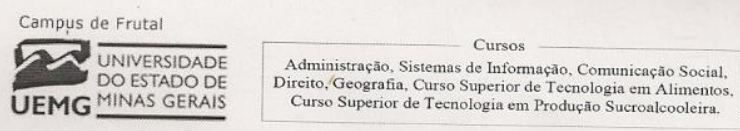

Frutal, 16 de março de 2012.

Ofício $n^{\circ} 054$ - alpfn

Assunto: Anuência para uso do Laboratório de Microbiologia da UEMG-Universidade do Estado de Minas Gerais - Campus de Frutal.

Prezados,

Em atenção à solicitação do Comitê de Ética e Pesquisa da Universidade de São Paulo, informamos a V.Sa., que o Campus local da Universidade do Estado de Minas Gerais, disponibiliza o Labora tório de Microbiologia, para execução dos experimentos da Tese de Doutorado, da doutoranda do Programa em Ciências da Saúde, Dra. Adriana Novaes Rodrigues.

Reiterando a autorização dada anteriormente, enfatizamos que a UEMG, encontra-se aberta para diálogos referentes a parcerias entre as Instituições, tendo como inspiração, projetos já em desenvolvimento entre as duas Instituições.

Colocando-nos à disposição de V. Sa., reiteramos protestos de estima e consideração.

Atenciosamente.
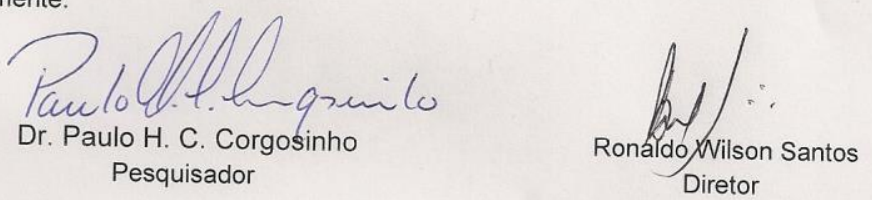

Ao

COMITÊ DE ÉTICA DA USP- Universidade de São Paulo

São Paulo - SP 


\section{ANEXO C}

\section{FACULdAdE de MEdicina dA UNIVERSIDAdE de SÃO PAULO}

Essas informações estão sendo fornecidas para sua participação voluntária neste estudo, cujo objetivo é identificar a presença de fungos na boca de trabalhadores rurais na região de Frutal, MG.

Durante a safra de cana-de-açúcar, de laranja, ou abacaxi e ao longo do período de trabalho (quatro vezes) será colhido material da parte de dentro da boca utilizando-se um "swab" (semelhante a um cotonete grande) procedimento que não trará nenhum dano ou dor a você. Qualquer dúvida pode ser esclarecida agora ou durante o exame. No momento da sua inclusão no estudo será feita uma entrevista com perguntas sobre você, seus hábitos e doenças anteriores. Tanto as informações do questionário quanto os resultados dos exames da boca serão usados de modo a caracterizar os grupos de trabalhadores, não havendo identificação dos entrevistados.

Garantia de acesso: em qualquer etapa do estudo, você terá acesso aos profissionais responsáveis pela pesquisa para esclarecimento de eventuais dúvidas. O principal investigador é o Dr. Alfésio Luís Ferreira Braga, que pode ser encontrado na Faculdade de Medicina da USP, Av. Dr. Arnaldo, 455, $1^{\circ}$ andar, sala 1304, Cerqueira César, CEP 01246-903, São Paulo, SP, telefone (11) 30618530. A pesquisadora executante é a Dra. Adriana Novaes Rodrigues, que pode ser encontrada na Sociedade Frutalense De Ensino Superior, Av. Brasília, 235, Vila Esperança, 38200-000 - Frutal, MG - Brasil, telefone: (34) 34236366. Se você tiver alguma consideração ou dúvida sobre a ética da pesquisa, entre em contato com o Comitê de Ética em Pesquisa (CEP) - Av. Dr. Arnaldo, 455 - Instituto Oscar Freire - 1ำ andar- tel: 3061-8004, FAX: 3061-8004- E-mail: cep.fmusp@hcnet.usp.br

É garantida a liberdade de você desistir do estudo a qualquer momento. Outros aspectos relevantes envolvendo a sua participação neste estudo:

- Direito de confidencialidade - as informações obtidas serão analisadas em conjunto com outros voluntários, não sendo divulgada a identificação de nenhum participante; • Direito de ser mantido atualizado - sobre os resultados parciais das pesquisas, quando em estudos abertos, ou de resultados que sejam do conhecimento dos pesquisadores; • Despesas e compensações - não há despesas pessoais para o participante em qualquer fase do estudo, incluindo exames e 
consultas. Também não há compensação financeira relacionada à sua participação. Se existir qualquer despesa adicional, ela será absorvida pelo orçamento da pesquisa; • Compromisso do pesquisador - utilizar os dados e o material coletado somente para esta pesquisa.

Acredito ter sido suficientemente informado a respeito das informações que li ou que foram lidas para mim, descrevendo o estudo ". Estudo Comparativo Da Microbiota Fúngica Em Mucosa de Cortadores de Cana-de-açúcar e Meio Ambiente Na Região do Triangulo Mineiro."

Eu discuti com o Professor Dr. Alfésio Braga e com a Dra. Adriana Novaes Rodrigues sobre a minha decisão em participar nesse estudo. Ficaram claros para mim quais são os propósitos do estudo, os procedimentos a serem realizados, seus desconfortos e riscos, as garantias de confidencialidade e de esclarecimentos permanentes. Ficou claro também que minha participação é isenta de despesas e que tenho garantia do acesso a tratamento hospitalar quando necessário. Concordo voluntariamente em participar deste estudo e poderei retirar o meu consentimento a qualquer momento, antes ou durante o mesmo, sem penalidades ou prejuízo ou perda de qualquer benefício que eu possa ter adquirido, ou no meu atendimento neste Serviço.

Assinatura do voluntário/representante legal

Data 11

Assinatura da testemunha

Data

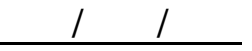

*para casos de voluntários menores de 18 anos, analfabetos, semi-analfabetos ou portadores de deficiência auditiva ou visual.

(Somente para o responsável do projeto)

Declaro que obtive de forma apropriada e voluntária o Consentimento Livre e Esclarecido deste paciente ou representante legal para a participação neste estudo.

Data

11


ANEXO D

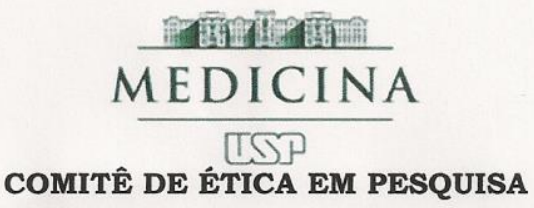

APROVAÇÃO

O Comitê de Ética em Pesquisa da Faculdade de Medicina da Universidade de São Paulo, em sessão de 25/04/2012, APROVOU o Protocolo de Pesquisa no 200/11 intitulado: "INCIDÊNCIA DE FUNGOS FILAMENTOSOS NA MUCOSA ORAL NORMAL DE TRABALHADORES RURAIS DA REGIÃO DE FRUTAL, MG.” apresentado pelo Departamento de PATOLOGIA

Cabe ao pesquisador elaborar e apresentar ao CEPFMUSP, os relatórios parciais e final sobre a pesquisa (Resolução do Conselho Nacional de Saúde no 196, de 10/10/1996, inciso IX.2, letra "c").

Pesquisador (a) Responsável: ALFÉSIO LUÍS FERREIRA BRAGA

Pesquisador (a) Executante: ADRIANA NOVAES RODRIGUES

CEP-FMUSP, 26 de Abril de 2012.

pllavemen.

Prof. Dr.Roger Chammas

Coordenador

Comitê de Ética em Pesquisa

Comitê de Ética em Pesquisa da Faculdade de Medicina

e-mail: cep.fmusp@hcnet.usp.br 


\section{BIBLIOGRAFIA}

Abreu PHB de, Alonzo HGA. Trabalho rural e riscos à saúde: uma revisão sobre - "uso seguro" de agrotóxicos no Brasil. Ciênc. Saúde coletiva. 2014;19(10):4197-4208.

Abu-Elteen KH, Hamad MA. Changing epidemiology of classical and emerging human fungal infections: a review. Jordan Journal of Biological Sciences (JJBS). 2012;5(4):215-229. Available from: http://jjbs.hu.edu.jo/files/v5n4/Binder1.pdf

Adhikari A, Reponen T, Lee SA, \& Grinshpun SA. Assessment of human exposure to airborne fungi in agricultural confinements: personal inhalable sampling versus stationary sampling. Annals of Agricultural and Environmental Medicine. 2004;11(2):269-277.

AFEIRA, 2015. Disponível em: http://www.ufrgs.br/afeira/materiasprimas/frutas/laranja/producao-produtividade.

Afonso SDOM. Aspergillus niger: sua utilização na indústria farmacêutica [dissertação]. Portugal: Instituto Superior de Ciências da Saúde Egas Moniz Caparica; 2015.

Agência Nacional de Vigilância Sanitária - ANVISA. Manual de Microbiologia Clínica para o controle de infecção relacionada à assistência à saúde, 2012. Módulo 8 - Detecção e Identificação dos Fungos de Importância Médica, 2007.

Aguiar CL, Menezes TJB. Produção de celulases e xilanases por Aspergillus niger IZ-9 usando fermentação submersa sobre bagaço de cana-de-açúcar. Boletim do Centro de Pesquisa de Processamento de Alimentos. 2000. v. 18, n. 1, p. 57-70.

Ainsworth GC. Introduction to the History of Mycology. Cambridge: Cambridge University Press; 1976.

Ainsworth G. Fungus Infections (Mycoses). In: Kiple, Kenneth, ed. The Cambridge World History of Human Desease. Cambridge: Cambridge University Press; 1993, p.730-734.

Al-Subai AAT. Air-borne fungi at Doha, Qatar. Aerobiologia. 2002;18(3-4):17583.

Alessi NP, Scopinho RA. A saúde do trabalhador do corte da cana-de-açúcar. In: Alessi NP. Filho AP, Pinheiro SA, Scopinho RA, Silva GB, editores. Saúde e Trabalho no Sistema Único de Saúde. São Paulo: Hucitec; 1994. p.121-51.

Alessi NP, Navarro VL. Saúde e trabalho rural: o caso dos trabalhadores da cultura canavieira na região de Ribeirão Preto, São Paulo, Brasil. Cad. Saúde Pública. Rio de Janeiro; 1997. v. 13, suple. 2.

Alexander P, Feine J, Huynh-Ba G, Vargas A, \& Oates TW. A critical review of diabetes, glycemic control and dental implant therapy. Clinical Oral Implants Research. 2013;24(2):117-127. 
Alexopoulos CJ, Mims CW, Blackwell M. Introductory Mycology. 4th ed. New York: John Wiley \& Sons; 1996.

Ali SA. Dermatoses ocupacionais. In: Mendes, R. (Ed.). Patologia do trabalho. Rio de Janeiro: Atheneu; 1995. p. 139-172.

Alison M. Innes Review of F. Blackburn 'Sugar-cane'. Journal of Tropical Ecology, 1985. p. 88.

Alves FJC. Progresso técnico na agricultura: mudança na organização e no processo de trabalho - o caso da cana-de-açúcar. In: Outras falas em processo de trabalho. Belo Horizonte: ed. Escola Sindical 7 de Outubro; 1992. pp. 117145.

Alves F. Migração de trabalhadores rurais do Maranhão e Piauí para o corte de cana em São Paulo. In: J. R. Novaes \& F. Alves (Orgs.). Migrantes: trabalho e trabalhadores no Complexo Agroindustrial Canavieiro (os heróis do agronegócio brasileiro). São Carlos: EDUFSCAR; 2007.

Amaral SM, Cortês AQ, Pires FR. Pneumonia nosocomial: importância do microambiente oral. J. bras. pneumol [on-line]. 2009 Nov [citado 1 ago. 2016]; 35(11):1116-1124.

Disponível

em: http://www.scielo.br/scielo.php?script=sci_arttext\&pid=S180637132009001100010\&lng=en.

Amorim DS, de-Maria-Moreira NL, de Amorim CDR, Santos SS, de Oliveira JM, Nunes CP, Gomes AP. Infecções por Aspergillus spp: aspectos gerais. Pulmão/ RJ. 2004;13(2);2. Disponível em: http://www.sopterj.com.br/revista/2004_13_2/08.pdf.

Anaissie EJ, McGinnis MR, Pfaller MA. Clinical mycology. Elsevier Health Sciences, 2009.

Anand BS, Alka S. Terlika Pandit Respiratory diseases among agricultural industry workers in India: a cross-sectional epidemiological study. Ann Agric Environ Med. 1999;6:115-126.

Andreae MO. Biomass burning: Its history, use and distribuion and its impact on environmental quality and global climat. In: Levine JS (ed.). Global biomass burning: atmospheric, climatic and biosphere implication. MIT Press, Cambridge, MA, 1991.

Angelini GARA, Balieiro FC, Saggin Jr OJ, Zanatta JA, Coutinho HLC, Salton JC, \& Franco AA. Impacto da retirada da palhada de áreas com cana-de-açúcar sobre os fungos micorrízicos arbusculares em solo de Cerrado, em Dourados, MS. Semana científica Joanna Dobereiner, outubro de 2010, Seropédica. Ciência para o Desenvolvimento Sustentável: anais... Seropédica: Embrapa Agrobiologia.

Aquino VR, Constante CC, Bakos L. Freqüência das dermatofitoses em exames micológicos em Hospital Geral de Porto Alegre, Brasil. An Bras Dermatol. 2007;82(3):239-44. 
Arango M, Castañeda E. Micosis Humanas. Procedimientos diagnósticos. Exámenes directos. Ediciones Rojo, Medellín. Editorial Presencia, Santafé de Bogotá, 1995.

Arbex MA. Avaliação dos efeitos do material particulado proveniente da queima da plantação de cana de-açúcar sobre a morbidade respiratória na população de Araraquara-SP [tese]. São Paulo: Faculdade de Medicina da Universidade de São Paulo; 2001.

Arbex MA, Bohm GM, Saldiva PHN, Conceição G, Popeii AG, Braga ALF. Assessment of the effects of sugar cane plantation burning on daily counts of inhalation therapy. Journal of the Air \& Waste Management Association 50. 2000. p. 1745-1749.

Arendorf TM, Walker DM. Oral candidal populations in health and disease. $\mathrm{Br}$ Dent J. 1979;147:267-72.

Arushdeep S, Umar F. Sugarcane bagasse: a potential medium for fungal cultures chinese. Journal of Biology. v. 2014.

Azenha MRC, Rubens B, Luiz G, de Lacerda SA. A retrospective study of oral manifestations in patients with paracoccidioidomycosis. Braz. Dent. J., Ribeirão Preto. 2012, v. 23, n. $6 . \quad$ Available from http://www.scielo.br/scielo.php?script=sci_arttext\&pid=S010364402012000600021\&lng=en\&nrm=iso. Access on 15 June 2014.

Bacon CW, White JF. Microbial endophytes. Marcel Dekker Inc., New York, N.Y, 2000.

Baker SE, Benneth JW. An overview of the genus Aspergillus. Mycology, New Jersey, v. 26, 2008. p. 551.

Barato MB. Fungos derivados da Antártica: biodiversidade e produção de enzimas lignocelulóticas a baixas e médias temperaturas [dissertação online]. São Paulo: Universidade Estadual Paulista, Instituto de Biociências de Rio Claro; 2014. Disponível em: http://hdl.handle.net/11449/123106.

Barbosa VS, Gomes VP, Petillo CR, Canabarro A. Presence of Candida sp. in diseased and healthy sites in patients with Chronic Periodontitis. Rev. Assoc. Paul. Cir. Dent. 2014;68(2):160-164.

Barbosa DSJC, Lobato PS, de Menezes SAF, de Alencar MTO, \& Pinheiro HHC. Perfil dos pacientes sob terapia intensiva com pneumonia nosocomial: principais agentes etiológicos. Rev Odontol UNESP. 2010;39(4):201-206.

Barbosa MALV. Os impactos ambientais causados pela monocultura da canade-açúcar no município de Americano do Brasil, 2006.

Barnes AC. The sugar cane. London: Hill Ed.; 1964. p. 456.

Barros, E. V. A matriz energética mundial e a competitividade das nações: bases de uma nova geopolítica. Disponível em: http://www.uff.br/engevista/9_1Engevista5.pdf. Acessado em: out. 2013. 
Barroso H, Meliço-Silvestre A, Taveira N. Microbiologia Médica. LIDEL, ed; 2014. v. 1.

Bierman WC, Van Arsdel Jr PP. Clinical evaluation of the patient with allergic and immunologic disease. In: Lockey RF, editor. Principles of Immunology and Allergy. Philadelphia: W.B Saunders; 1987. p.1-26.

Benchimol J. Adolph Lutz e a dermatologia em perspectiva histórica. In: Dermatologia e Micologia. Benchimol, Jaime e SÁ, Magali (orgs). Rio de Janeiro: Editora Fiocruz; 2004.

Bertoni MS. Contributions á l'étude botanique des plantes cultivées. I. Essai d'une monographie du genre Ananas. Anales Cient. Paraguayos. 1919. v. 2, n. 4, p. 250-322.

Bertoni T, Takao E, Dias JR, \& Svidzinski TIE. Paracoccidioidomicose e tuberculose: diagnóstico diferencial. J Bras Patole Med Lab. 2010;46(1):17-21.

Bitencourt DP, Ruas AC, Maia PA. Análise da contribuição das variáveis meteorológicas no estresse térmico associada à morte de cortadores de canade-açúcar. Cad. Saúde Pública. Rio de Janeiro, 2012. v. 28, n. 1. Disponível em: http://www.scielosp.org/scielo.php?script=sci_arttext\&pid=S0102-

311X2012000100007\&lng=en\&nrm=iso. Acessado em 26 de julho de 2014.

Blakburn F. Sugar Cane: The origin and history of the sugar cane. London, Longman; 1984. p. 1-32.

Bleger J. Temas de psicologia: entrevistas e grupos. São Paulo: Martins Fontes; 1990.

Botelho AV, Reis LM. Dicionário histórico Brasil: colônia e império. Editora Dimensão; 1998.

Bowman SM, Free SJ. The structure and synthesis of the fungal cell wall. Bioessays. 2006;28(8):799-808.

Brandes EW. Origin, dispersal and use breeding of the Melanesian Garden sugarcane and their derivates. Saccharum officinarum L Proceding International Society of Sugar Tecnhologists: 9-709-750.

Brás S, Sabino R, Laureano A, Simões H, Fernandes C, Marques-Pinto G, Veríssimo C. Cutaneous infection by different Alternaria species in a liver transplant recipient. Medical Mycology Case Reports. 2015;8:1-4. Available from: http://doi.org/10.1016/j.mmcr.2015.01.004.

Brasil.Ministério Da Agricultura e Pecuária.Produção Citrus no Brasil, 2010.

Brasil. Fundação João Pinheiro (FJP)a. Centro de Estatística e Informações (CEI), 2010.

Brasil. Ministério da Saúdeb. Agência Nacional de Vigilância Sanitária (ANVISA). Detecção e identificação dos fungos de importância médica. Salvador: Ministério da Saúde; 2012. 
Brasil. Instituto Brasileiro de Geografia e Estatística (IBGE)c. Senso parcial, 2010.

Brasil. Ministério da Saúde. Doenças relacionadas ao trabalho: manual de procedimentos para os serviços de saúded. Brasília (DF); 2006.

Brasil Ministério da Saúde. Instituto Nacional de Câncer, Coordenação de Prevenção e Vigilânciae. Consenso sobre Abordagem e Tratamento do Fumante. Rio de Janeiro: Ministério da Saúde; 2012.

Brasil. Ministério da Saúde. Instituto Nacional de Câncer, Coordenação de Prevenção e Vigilânciaf. Programa Nacional de Controle ao Tabagismo. Rio de Janeiro: Ministério da Saúde; 2016.

Brasil. Ministério da Saúde. Ceratite fúngicag. Disponível em: http://www.hse.rj.saude.gov.br/profissional/revista/37b/cerati.asp. Acesso em: 12 fev. 2011.

Brasil. Ministério da Saúde. Diretrizes e normas regulamentadoras de pesquisa envolvendo seres humanosh. Brasília (DF): Ministério da Saúde; 1997.

Brasil. Ministério da Saúde. Secretaria de Vigilância em Saúdei. Vigitel Brasil 2013: vigilância de fatores de risco e proteção para doenças crônicas por inquérito telefônico. Brasília: Ministério da Saúde; 2014. (Série G. Estatística e Informação em Saúde).

Brauner MCC, Zaro L. Saúde e meio ambiente: fatores condicionantes para a concretização do direito à saúde. JURIS, Rio Grande; 2012;17:53-74.

Brilhante RSN, Paixão GC, Salvino LK, Diógenes MJN, Bandeira SP, Rocha MFG, Santos JBF, Sidrim JJC. Epiodemiologia e ecologia das dermatofitoses na cidade de Fortaleza: Trichophyton tonsurans como importante patógeno emergente da Tinea capitis. Revista da Sociedade Brasileira de Medicina Tropical. 2000. v.33, n.5, p.417-425.

Bruns T. Evolutionary biology: a kingdom revised. Nature [S.I.: s.n.]. 2006;443(7113):758-61. Available from: http://www.nature.com/nature/journal/v443/n7113/full/443758a.html.

Caetano LCS, Ventura JA, Balbino J, de Souza MAURO. Behavior of pineapple genotypes Fusariose resistant compared to suscetible comercial cultivares. Revista Brasileira de Fruticultura. 2015;37(2):404-409.

Camara RNDA patrimonialização de material genético brasileiro. $O$ estudo de caso da coleção de fungos filamentosos do Instituto Oswaldo Cruz. Dissertação de Mestrado apresentada à Coordenação do Programa de Pós-Graduação em Museologia e Patrimônio UNIRIO/MAST - Rio de Janeiro, 2008.

Camacho RS. Paradigmas em disputa na educação do campo [tese]. São Paulo: Universidade Estadual Paulista, Faculdade de Ciências e Tecnologia; 2014, 806 f. Disponível em: http://hdl.handle.net/11449/108661.

Campbell CK, Johnson EM. Identification of pathogenic fungi. John Wiley \& Sons, 2013. 
Campos FMF, Santos M. Setor Sucroalcooleiro em Minas Gerais. Sindicato da Indústria do Açúcar e do Álcool de Minas Gerais-SIAMIG. Belo Horizonte; 2008. Disponível em: http://www.siamig1.com.br/index.php?option=com_content\&task=view\&id=262\& Itemid=95 >. Acesso em: 25 jan. 2015.

CanaOeste. Disponível em: http://www.canaoeste.com.br/index.html- 2012.

Castro PRC, Kluge RA. editores. Ecofisiologia de culturas extrativas: cana-deaçúcar, seringueira, coqueiro, dendezeiro e oliveira. Cosmópolis: Editora Stoller do Brasil; 2001. p. 138.

Castro JD. Geografia da Fome [monografia]. Rio de Janeiro: Faculdade de Educação e Ciências Humanas de Anicuns - FECHA; 1952, p.73.

Castro TM, Peixoto PG, Bussoloti FI, Nascimento VX, Xavier SD. Detecção de HPV na mucosa oral e genital pela técnica PCR em mulheres com diagnóstico histopatológico positivo para HPV genital. Revista Brasileira de Otorrinolaringologia. 2009;75(2):167-171.

Carvalho LP, do Nascimento LP. Administração de Recursos Humanos. 2a ed. v. 2. Editora: CENGAGE LEARNING; 2012.

Ceccato ADF, Junior C, Cuissi RC, Monteschi M, Oliveira NG, Padovani CR, \& Ramos D. Absenteeism due to occupational diseases among sugarcane workers. Cadernos de Saúde Pública. 2014;30(10):2169-2176.

CDC. Centers for Disease Control and Prevention - Oropharyngeal / Esophageal Candidiasis Thrush, 2014g. Available from: http://www.cdc.gov/fungal/diseases/candidiasis/thrush/index.html

CDC. Centers for Disease Control and Prevention -Symptoms of Aspergillosis, 2014j. Available from: http://www.cdc.gov/fungal/diseases/aspergillosis/symptoms.html

Cesnik R, Miocque J. Melhoramento da cana-de-açúcar. Brasília: Embrapa Informação Tecnológica; 2004.

Chalfoun SM, Batista LR. Fungos associados a frutos e grãos de café. Aspergillus \& Penicillium.Brasília. DF: Embrapa; 2003. p. 69.

Chao HJ, Schwartz J, Milton DK, \& Burge HA. Populations and determinants of airborne fungi in large office buildings. Environmental health perspectives. 2002;110(8):777.

Chang CW, Chung H, Huang CF, Su HJJ. Exposure assessment to airborne endotoxin, dust, ammonia, hydrogen sulfide and carbon dioxide in open style swine houses. The Annals of Occupational Hygiene. 2001;45(6):457-465.

Chor D, Faerstein E, Alves MGM, Lopes CS. How reproducible is self-reported information on exposure to smoking, drinking, and dietary patterns?. Evidence among Brazilian adults in the pro-health study. São Paulo: Med J; 2003;12:63-6. 
CitrusBr. Cultivo de laranja. Disponível em: www.citrusbr.com.

CityBrasil. História da Cidade. Disponível em: http://www.citybrazil.com.br/mg/frutal/historia-da-cidade. Acessado em: 12 de janeiro de 2016.

Clemente JC, Ursell LK, Parfrey LW, Knight R. The impact of the gut microbiota on human health: an integrative view. Cell. 2012;148(6):1258-1270.

Ctenas MLB, Quast D. Abacaxi. In: brasileiras. São Paulo: C2; 2000, p. 41-45. (Ed.). Frutas das terras

Colakoglu G. Indoor and outdoor mycoflora in the different districts of the city of Istanbul-Turkey. Indoor and Built Environment. 13:2(2004):91-100.

Colla LM, Reinehr C. O, Costa J. A. V. Aplicações e produção de lipases microbianas. Revista CIATEC-UPF; 2013, v. 4, n. 2, p. 1-14.

Comarella JD, Saraiva PGC, Saraiva FP. Corneal ulcer: a retrospective study of a case seen at the Hospital das Clínicas, Federal University of Espirito Santo. Rev. bras. oftalmol. Rio de Janeiro, 2015, v. 74, n. 2, p. 76-80. Available from: http://www.scielo.br/scielo.php?script=sci_arttext\&pid=S0034-

$72802015000200076 \&$ Ing=en\&nrm=iso. Access on: 26 mar. 2016.

Conab (Companhia Nacional de Abastecimento). Acompanhamento de safra brasileira: cana-de-açúcar. Brasília: Conab, 2009. Disponível em: http://www.conab.gov.br/conabweb/download/safra/2_levantamento2009_set20 09.pdf. Acessado em: set. 2009.

Conab (Companhia Nacional de Abastecimento). Safra de cana-de-açúcar no Brasil. 2015. Disponível em: http://www.conab.gov.br/. Acessado em: 01 fev. 2015.

Conab (Companhia Nacional de Abastecimento). Acompanhamento da Safra Brasileira de laranja. Safra 2013/2014, terceiro levantamento. Dezembro de 2014.

Coronado-Castellote L, Jiménez-Soriano Y. Clinical and microbiological diagnosis of oral candidiasis. Journal of Clinical and Experimental Dentistry. 2013;5(5):e279-86. Available from: doi:10.4317/jced.5124.

Costa M, Passos XS, Souza LKH, Miranda ATB, Lemos JD.A, Oliveira Júnior JGD, Silva MDRR. Epidemiology and etiology of dermatophytosis in Goiania, GO, Brazil. Revista da Sociedade Brasileira de Medicina Tropical. 2002;35(1):1922.

Costa SEA. Análise ergonômica do trabalhador de colheita de citros: comparativos dos métodos de colheita manual e semi mecanizado [dissertação]. FAPESP, 2013.

Costa SEA, Camarotto JA. An ergonomics approach to citrus harvest mechanization. Work; 2012, v. 41, n. Supplement 1, p. 5027-5032. 
Coopercitrus. Adensamento de plantio é estratégia para melhorar produtividade e lucratividade da laranja. +Laranja, 289 ed. 2010. Disponível em: $\mathrm{http}: / \mathrm{www}$.revista coopercitrus.com.br/?pag=materia\&codigo=5921. Acesso em: 02 jun. 2015.

Cotrim G. História Global: Brasil e geral. São Paulo: Editora Saraiva; 2005.

Cotten TK, \& Munkvold, GP. Survival of Fusarium moniliforme, F. proliferatum, and F. subglutinans in maize stalk residue. Phytopathology. 1998;88(6):550-555.

Cui J, Robinson DJ, Versace F, Lam YC, Minnix AJ, Karam-hage M, Dani AJ, Kosten RT, Wetter WD, Brown LV, Cinciripini MP. Diefferential cigarrete-related startle cue reactivity among light, moderate, and heavy smokers. Addict Behav. 2012;32:885-9.

Cui L, Morris A, Ghedin E. The human mycobiome in health and disease. Genome medicine. 2013;5(7):63. Available from: https://genomemedicine.biomedcentral.com/articles/10.1186/.

da Cruz, Kapitski M, Nascimento de M, Trevisani DM. Avaliação clínica da cavidade bucal de pacientes internados em unidade de terapia intensiva de um hospital de emergência. Rev Bras Ter Intensiva. 26.4;(2014):379-383.

da Silva N, Junqueira VCA. Métodos de análise microbiológica de alimentos. (Manual Técnico, 14). Campinas: ITAL; 1995, p. 229.

da Silva PV, Monquero PA, Munhoz WS. Controle em pós-emergência de plantas daninhas por herbicidas utilizados na cultura da cana-de-açúcar. Revista Caatinga. 2015, v. 28, n. 4, p. 21-32.

da Silva RP et al. Controle estatístico aplicado ao processo de colheita mecanizada de cana-de-açúcar. Eng. Agric. Jaboticabal. 2008, v. 28, n. 2, p. 292304.

Dalfré JT, Brandão JPR, Guimarães DB, Giancoli NA, Carvalho JLD, Andrade DO. et al. Microbiota fúngica da conjuntiva, da cana-de-açúcar e de anemófilos da Região Canavieira de Monte Belo - Minas Gerais. Arq. Bras. Oftalmol. 2007;70(3):445-449.

Davies RR, Ganderton MA, Savage MA. Clin Allergy. Human nail dust and precipitating antibodies to Trichophyton rubrum in chiropodists. 1983;13(4):30915.

Dawson L, Boopathy R. Cellulosic ethanol production from sugarcane bagasse without enzymatic saccharification. Bioresources. 2008, v. 3, n. 2, p. 452-460.

de Almeida DV, Coimbra CC, da Silva CF, Lyra ECQ, Silva FLC, Cavaleiro LHS. Epidemiologia dos pacientes no Departamento dermatológico de uma unidade de saúde Rev. para. med. 2004;18(2):45-49.

de Andrade SL. Fungos associados a tumores de cabeça e pescoço [dissertação]. Pernambuco: Universidade Federal Pernambuco; 2010. 
de Azevedo FA, Lanza NB, Sales CRG, Silva KI, Barros AL, de Negri JD. Poda na citricultura. Citrus Research \& Technology, Cordeirópolis. 2013, v.34, n.1, 2013. p.17-30.

de Bragança SL. Introdução à analise estatístia de variáveis dicotômicas e aplicações em dados socioeconômicos. Revista Brasileira de Economia;1977. v. 31, n. 2, p. 323-352.

de Carli BMG, de Carli JP, da Silva SO, Linden MSS, Trentin MS, \& de Medeiros UV. Doenças ocupacionais com manifestações bucais. Odonto. 2013;20(40):4955. Disponível em: http://dx.doi.org/10.15603/2176-1000/odonto.

de Ferreira MWF, Pereira RA, Schmidt FR, de SAJ, do Nascimento KNF. Cadeia produtiva da cachaça Triunfo: Um estudo de caso. Revista Verde de Agroecologia e Desenvolvimento Sustentável. 2012;7(3):41-45.

de Freitas RMC. Pulmonary paracoccidoidomycosis: radiology and clinicalepidemiological evaluation. Rev. Soc. Bras. Med. Trop. Uberaba; 2010, v. 43, n. 6. Available from: http://www.scielo.br/scielo.php?script=sci_arttext\&pid=S0037$86822010000600010 \& \operatorname{lng}=e n \& n r m=i s o$. Acesso em: 11 fev. 2011.

de Hoog GS, Guarro J, Figueras MJ, Gené J. Atlas of Clinical Fungi. 2nd ed. Baarn/Reus, Centralbureau voor Schimmelcultures. Universitat Rovira i Virgili, 2000.

de Macedo PM, de Oliveira LC, Freitas DFS, da Rocha JA, Freitas ADA, Nucci $M$, \& do Valle ACF. Acute paracoccidioidomycosis due to Paracoccidioides brasiliensis S1 mimicking hypereosinophilic syndrome with massive splenomegaly: diagnostic challenge. PLoS Negl Trop Dis. 2016;10(4). Available from: http://journals.plos.org/plosntds/article?id=10.1371/journal.pntd.0004487.

de Melo ML. O açúcar e o homem. MEC - Instituto Joaquim Nabuco de Pesquisas Sociais. Recife, 1975.

de Oliveira ER de, Mendes EdePP. Setor Sucroenergetico e transformações espaciais em Frutal. Espaço em Revista. 2014, v. 16, n. 1, p. 33-50.

de Oliveira IM. Cana-de-açúcar: um estudo sobre os impactos econômicos, sociais e ambientais da indústria canavieira no Estado de Goiás. Fasem Ciências. 2012, v. 1, n. 1, p. 63-72.

de Souza VE, Reis RC, de Jesus JL, Junghans DT, Souza FVD. Caracterização físico-química de novos híbridos de abacaxi resistentes à fusariose. Ciência Rural. 2013;43(7):1155-1161.

dos Santos, D W; Wagner, R. Caracterização química parcial de polissacarídeos da parede celular de fusarium subglutinans. Saúde, v. 1, n. 3, 2014.

Dean W. A ferro e fogo: a história e a devastação de mata atlântica brasileira. São Paulo: Cia das Letras, 1996.

Dejours C. Subjetividade, trabalho e ação. Revista Produção. São Paulo: 2004, v. 14, n.3, p. 27-34. 
Delgado AA, Azeredo CMA. Elementos de tecnologia e engenharia do açúcar de cana; Piracicaba: Escola Superior de Agricultura Luiz de Queiroz, 1977, v. II.

Delgado AA, Cesar M. AA. Elementos da tecnologia e engenharia de açúcar de cana. Piracicaba: Departamento de Tecnologia Rural - ESAL; 1977, v. 1, p. 363.

Denilson WC, Caroll GC. The Primitive Ascomycete A New Look at an Old Problem. Mycologia; 1966;58:249-26.

Dias M. Manual de impactos ambientais: orientações básicas sobre aspectos ambientais de atividades produtivas. Embrapa Solos-Outras publicações técnicas (INFOTECA-E), 2012.

Diawara M, Gomes MFM, Lirio VS, \& Tosta MDCR. Dimensionamento do agronegócio no Estado de Minas Gerais. Revista de Economia e AgronegócioREA. 2015, v. 3, n. 2.

Diesse - Departamento Intersindical de Estatística e Estudos Socioeconômicos. Disponível em: https://www.dieese.org.br/sitio/buscaDirigida?itemBusca=\&comboBuscaDirigida $=$ ANO $\% 7 C 2015$

Dignani MC, \& Anaissie E. Human fusariosis. Clinical Microbiology and Infection. 2004;10(s1):67-75.

Diniz SPSDS. Micotoxinas. Campinas: Livraria e Editora Rural; 2002.

Dollive S, Peterfreund GL, Sherrill-Mix S, Bittinger K, Sinha R, HoffmannC. et al. A tool kit for quantifying eukaryotic rRNA gene sequences from human microbiome samples. Genome Biol. 2012;13:R60.

Domsch KH, Gams W, Anderson TH. Compendium of soil fungi. New York: Academic Press; 1980, p. 859.

Domsch KH, Gams W, Anderson TH. Compendium of soil fungi. New York: Academic Press; 1993.

dos Santos ASC, Leite RB. Integração entre Medicina, Enfermagem e Odontologia do Trabalho: uma conquista para a população. Revista Brasileira de Odontologia. 2012;69(1):111-115.

dos Santos DW, Wagner R. Caracterização química parcial de polissacarídeos da parede celular de fusarium subglutinans. Saúde. 2014, v. 1, n. 3.

dos Santos, WA, da Silva BM, Passos ED, Zandonade E, Falqueto A. Associação entre tabagismo e paracoccidioidomicose: um estudo de caso-controle no Estado do Espírito Santo, Brasil. Association between smoking and. Cad. Saúde Pública. 2003;19(1):245-253. Disponível em: http://www.scielo.br/scielo.php?script=sci_arttext\&pid=S0102-

$311 X 2003000100027 \&$ Ing=en\&nrm=iso. Acesso em: 7 set. 2015.

Duarte GJ, Oliveira VC de B. Trabalho no corte da cana-de-açúcar e as condições de vida relevante no processo Saúde/Doença dos trabalhadores. 
Superintendência de Vigilância em Saúde. Disponível em: http://www.sgc.goias.gov.br/upload/arquivos/2013-05/o-trabalho-no-corte-decana-deacucar- e-as-condicoes-de-vida-relevantes-no-processo-saude-doencados-trabalhadores.pdf

Dutkiewicz J, Krysińska-Traczyk E, Skórska C, Sitkowska J, Prazmo Z, Golec M. Exposure to airborne microorganisms and endotoxin in herb processing plants. Ann Agric Environ Med. 2001;8(2):201-11.

El-Solh AA, Pietrantoni C, Bhat A, Okada M, Zambon J, Aquilina A, \& Berbary E. Colonization of dental plaques: a reservoir of respiratory pathogens for hospitalacquired pneumonia in institutionalized elders. Chest. 2004;126(5):1575-1582.

Elias AA, Mahara-Daian GLP, Cassunde MDO, Rodrigues F.M. M, Xavier R. F, Ramos E. M. C, Ramo D. Análise do transporte mucociliar de indivíduos fumantes em diferentes períodos de abstinência. Rev Bras Fisioter. 2010;14(Supl. 1):303.

Embrapa. Agência de Informação: cana-de-açúcar. Disponível em: http://www.agencia.cnptia.embrapa.br/gestor/cana-de-

acucar/arvore/CONTAG01_110_22122006154841.html. Acessado em: maio 2010.

Embrapa. Ministério Agricultura e Desenvolvimento, Cultura de frutas. Disponível em: $\quad$ https://www.agencia.cnptia.embrapa.br/gestor/cana-deacucar/arvore/CONTAG01_79_22122006154841.html. Acessado em: 03 set. 2011.

Empresa de Pesquisa Agropecuária de Minas Gerais (EPAMIG) - Belo Horizonte/Minas Gerais. Citricultura: Renovação Tecnológica. Informe Agropecuário. 2007, № 52.

Empresa de Pesquisa Agropecuária de Minas Gerais (EPAMIG) - Belo Horizonte/Minas Gerais. Citricultura: 2 Encontro Técnico da Citricultura. 2015.

Espinell-Ingroff AV. Medical mycology and training in the United States: a historical analysis. 2003.

Esposito E, Azevedo JL. Fungos: uma introdução à biologia, bioquímica e biotecnologia. 2a ed. Caxias do Sul: EDUCS; 2010, v. 01. p. 638.

Esteves JA, Cabrita JD, Nobre GN. Micologia Médica. 2a ed. Lisboa: Fundação Caloute Gulbenkian; 1990.

Evanschitzky H, lyer GR, Plassman, Hilke, Niessing, Jorge, Meffert, Heribert. The relative strength of affective commitment in securing loyalty in service relationships. Journal of Business Research. 2006, v. 59, 1207-1213.

Ezzati M, Riboli E. Behavioral and dietary risk factors for noncommunicable diseases. N Engl J Med. 2013;369:954-64. 
Faria NA. Aspectos ecológicos e clínicos da flora micótica anemófila de Belo Horizonte [tese]. Belo Horizonte: Faculdade de Medicina da Universidade Federal de Minas Gerais; 1987.

Faria RI, Neves MJ, Ricardo E, Santos AJ, Silva AT, Costa de OS, Pina-Vaz C. Species distribution and in vitro antifungal susceptibility profiles of yeast isolates from invasive infections during a Portuguese multicenter survey. European Journal of Clinical Microbiology \& Infectious Diseases. 2014;33(12):2241-2247.

Fausto B. História do Brasil. 11a ed. São Paulo: Edusp; 2006.

Fernandes BC. Desenvolvimento histórico da citricultura [monografia]. São Paulo: Universidade Estadual Paulista; 2010.

Fernandes OG, da Costa VGH, da Costa VFE, Dias PM. Uso de Substâncias Alternativas no Controle do Fungo Fusarium solani. Cadernos de Agroecologia. 2015;9(4).

Fidalgo O. Introdução a Micologia Brasileira. São Paulo: Rickia; 1968, v3.

Findley K, Oh J, Yang J, Conlan S, Deming C, Meyer JA, \& Kong $\mathrm{HH}$. Topographic diversity of fungal and bacterial communities in human skin. Nature. 2013;498(7454):367-370.

Fiocruz - Instituto Oswaldo Cruz. Disponível em: https://agencia.fiocruz.br/cole\%C3\%A7\%C3\%A3o-de-culturas-de-fungosfilamentosos-completa-90-anos-de-hist\%C3\%B3ria

Fischer F, Cook NB. Fundamentals of diagnostic mycology. Philadelphia: Saunders; 1998.

Fisher MC, Henk DA, Briggs CJ, Brownstein JS, Madoff LC, McCraw SL, \& Gurr SJ. Emerging fungal threats to animal, plant and ecosystem health. Nature. 2012;484(7393):186-194. Available from: http://doi.org/10.1038/nature10947.

Fitzpatrick TB. Tratado de Dermatologia. $7^{\text {a }}$ ed. São Paulo: Editora Revinter; 2011.

Fonseca LEP. Alcoolismo e distúrbios carenciais. In: Fortes JRA, Cardo WN, editores. Alcoolismo: diagnóstico e tratamento. $2^{\mathrm{a}}$ ed. São Paulo: Sarvier; 1991. p.129-39.

Freitas G. Micologia geral, micoses cutaneas e mucocutaneas, micoses subcutaneas e sistemicas. In Ferreira V, Sousa J, ed. lit. - Microbiologia. Lisboa: Lidel; 2000, p. 291-343.

Freitas MA, Pedrosa EMR, Mariano RLR, \& Maranhão SRVL. Seleção de Trichoderma spp: como potenciais agentes para o biocontrole de Meloidogyne incógnita em nada de açúcar (2012). Nematropica. 2012;42(1):115-122.

Freire WJ, Cortez LAB. Vinhaça de cana-de-açúcar. Guaíba: Agropecuária; 2000. p. 203. 
Fundecitrus. Reestimativa da safra de laranja 2015/16 do cinturão citrícola de São Paulo e Triângulo/Sudoeste Mineiro. 2016.

Gaetti-Jardim E, Monti LM, Ciesielski FIN, Gaetti-Jardim EC, Okamoto AC, Schweitzer CM, \& Avila-Campos MJ. Subgingival microbiota from Cebus apella (capuchin monkey) with different periodontal conditions. Anaerobe. 2012;18(3):263-269.

Gallo DO, Nakano SS, Neto RPL, Carvalho GC, Batista E, Berti Filho JRP, Parra RA, Zucchi SB, Alves \& Vendramim JD. Manual de entomologia agrícola. São Paulo: Agronômica Ceres; 1988.

Gambale W, Purchio A. Influência de fatores abióticos na dispersão aérea de fungos na cidade de São Paulo. Rev Microbiol. 1983;14:204-14.

Geiser DM, Jimenz GMM, Kang S, Mkalowska I, Veeraraghavan N, Ward TJ, Zhang N, Kuldau GA, O'Donnell K. Fusarium-IDv.1.0: A DNA sequence database for identifying Fusarium. European Journal of Plant Pathology. 2004;110:473479.

Gestão do campo. Disponível em: http://www.gestaonocampo.com.br/. Acessado em: 2015.

Giolo SR. Introdução à análise de dados categóricos: minicurso de estatística. Piracicaba: [s.n.], 2012. Disponível em: http://www.ufpr.br/ Giolo/CE073/. Acesso em: 10 fev. 2013.

Giraldes A. Levantamento de Necessidades de Treinamento. In: Manual de Treinamento e Desenvolvimento. São Paulo: Pioneira; 1999.

Giro, V. B. (2011). Crescimento do abacaxizeiro 'vitória'em resposta à aplicação de vermicomposto, ácidos húmicos e bactérias promotoras de crescimento (Doctoral dissertation, Dissertação (Mestrado Produção Vegetal)-Universidade Estadual do Norte Fluminense, Campos dos Goytacazes).

Góes AMD, Silva LDS, Araújo SDA, Cruz SGD, Siqueira WC, \& Pedroso ERP. Paracoccidioidomicose (doença de Lutz-Splendore-Almeida): etiologia, epidemiologia e patogênese. RMMG. 2014, p. 61-65.

Ghannoum MA, Jurevic RJ, Mukherjee PK, Cui F, Sikaroodi M, Naqvi A, \& Gillevet PM. Characterization of the oral fungal microbiome (mycobiome) in healthy individuals. PLoS Pathogens. 2010; 6(1). Available from: http://journals. plos.org/plospathogens/article?id=10.1371/journal.ppat.1000713.

Ghannoum MA, Mukherjee PK. The Human Mycobiome and its Impact on Health and Disease. Current Fungal Infection Reports. 2013;7(4):345-350. Available from: http://link.springer.com/article/10.1007/s12281-013-0162-x.

Godinho R, Lanza M, Godinho A, Rodrigues A, Assiz TM. Freqüência de positividade em teste cutâneo para aeroalérgenos. Rev. Bras. Otorrinolaringol. 2003;69(6):824-8. 
Goes T, Bailão EFL, Correa CR, Bozzi A, Santos LI, Gomes A, \& Goes AM. New developments of RNAi in Paracoccidioides brasiliensis: prospects for highthroughput, genome-wide, functional genomics. PLoS Negl Trop Dis. 2014;8(10):e3173.

Goldsmith L, Katz S, Gilchrest B, Paller A, Leffell D. \& Wolff K. Fitzpatrick's Dermatology in General Medicine, eighth edition. McGraw-Hill, 2011, v. 1.

Gonçalves DB. Considerações sobre a expansão recente da lavoura canavieira no Brasil. Informações Econômicas. São Paulo. 2009, v. 39, n. 10, p. 70-82.

Gonçalves VN, Cantrell CL, Wedge DE, Ferreira MC, Soares MA, Jacob MR, \& Zani CL. Fungi associated with rocks of the Atacama Desert: taxonomy, distribution, diversity, ecology and bioprospection for bioactive compounds. Environmental microbiology. 2016;18(1):232-245.

Gomes GMF, de Vasconcelos AM, do Egito AS, da Costa CJ, de Oliveira FNL, \& Salles HO. Biodegradation of sugarcane bagasse by microorganisms from sheep or goats. Bioscience Journal. Uberlândia; 2015, v. 31, n. 1, p. 204-214.

Gomes SDC. Uma inserção dos migrantes nordestinos em São Paulo: o comércio de retalhos. Imaginário. 2006, v.12, n. 13, p.143-169.

Gomes MJP. Gênero Clostridium spp. LABACVET, Microbiologia Clínica. 2013. Disponível em: http://www.ufrgs.br/labacvet/pdf/clostridium.pdf. Acessado em: 03 jun. 2014.

Gonzaga MA, Donatelli S, Tencarte APR, Adissi PJ, Santos EID. Análise coletiva do trabalho executado no cultivo do abacaxi no município de Guaraçaí, São Paulo. Ed. 2014. Disponível em: http://www.fundacentro.gov.br/.

Gouveia N. Saúde e meio ambiente nas cidades: os desafios da saúde ambiental. Saúde e Sociedade. 1999;(8)1:49-61.

Goyer N, Lavoie J, Lazure L, Marchand G. Les bioaérosols en milieu de travail: guide d'évaluation, de contrôle et de prévention. Études et recherches, guide technique T-23. Institut de recherche Robert-Sauvé en santé et en sécurité du travail. 2001, p. 63.

Graça MG. Avaliação de método molecular para detecção direta de Fusarium em água [tese]. Programa de doenças infecciosas e parasitárias.São Paulo: Universidade de São Paulo; 2015.

Granyt C, Hunter CA, Flanningan B, Bravery AF. The moisture requirements of moulds isolated from domestic dwellings. International Biodeterioration. 1988;25:259-284.

Guarro J, Gené J. Fusarium infections: criteria for the identification of the responsible species. Mycoses. 1992;35:109-114.

Guimarães AR, Matos PFD. A produção de abacaxi como forma de (re)organização produtiva da agricultura familiar em Monte Alegre De Minas- 
MG. In: 210 Encontro Nacional De Geografia Agrária - Universidade Federal de Uberlândia, 2012.

Guimarães AR. Agricultura familiar em Monte Alegre de Minas-MG: Persistência e resistência dos produtores de abacaxi. In: 10 Simpósio Mineiro de GeografiaAlfenas-MG, 2014.

Guerra FL, Cunha EG da, Silva ACSB, Knop S. Análise das condições favoráveis à formação de bolor em edificação histórica de Pelotas-RS, Brasil. Ambient. constr. [online]. 2012, v. 12, n. 4 [citado em 18-07-2016], p. 7-23. Disponível em: http://www.scielo.br/scielo.php?script=sci_arttext\&pid=S1678-

$86212012000400002 \& \operatorname{lng}=e n \& n r m=i s o$.

Haley LD, Trandel J, Coyle MB. Cumitech II: practical methods for culture and identification of fungi in the clinical microbiology laboratory. Coordinating ed., Sherris J. C. American Society for Microbiology, Washington, D.C; 1980.

Hanson JR. The Chemistry of Fungi. [S.I.]: Royal Society of Chemistry; 2008.

Hibbett DS, Binder M, Wang Z. Fossil mushrooms from Miocene and Cretaceous ambers and the evolution of homobasidiomycetes. Am. J. Bot. 1997;84:981-991.

Hiroishi WK, Rosetti E, Orenha ES, \& Naressi SCM. Odontologia do Trabalho: um novo olhar sobre a saúde bucal do trabalhador. Brazilian Dental Science. 2012;14(3/4):66-76.

Höfling FJ, Barros MDL, Alves CBAA, de Laet SMP, Gonçalves BR. Colonização bucal por espécies de Candida - Parte I. Prevalência e colonização. Revista da Faculdade de Odontologia-UPF. 2011;9(1).

Hosmer Jr DW, Lemeshow S, \& Sturdivant RX. Assessing the fit of the model. Applied Logistic Regression, Third Edition. 2013, p. 153-225.

Hosoi J, Hariya T, Denda MT. Regulation of the cutaneous allergic reaction by humidity. Contact Dermatitis. [S. I.], 2000, v. 42, p. 81-84.

Huprikar S, \& Shoham S. Emerging fungal infections in solid organ transplantation. American Journal of Transplantation. 2013;13(Suppl 4):262271. Available from: http://doi.org/10.1111/ajt.12118.

lamanaka BT, Oliveira IS, Taniwaki MH. Micotoxinas em Alimentos. Anais da Academia Pernambucana de Ciência Agronômica. 2013. v. 7, p. 138-161.

INDEX FUNGORUM. Disponível em: http://www.indexfungorum.org/Names/Names.asp. Acessado em: out. 2011.

Instituto Nacional do Câncer (INCA). Disponível em: http://www2.inca.gov.br/wps/wcm/connect/inca/portal/home.

Instituto Brasileiro de Geografia e Estatístico-IBGE. Dados sobre a área do município, socioeconômico e da cultura temporária da cana-de-açúcar. Disponível em: http://www.ibge.gov.br/cidadesat/topwindow.htm?1. Acesso em: 01 jan. 2016. 
Innes AM. Review of F. Blackburn 'Sugar-cane'. Journal of Tropical Ecology. 1985;1, p. 88. Available from: doi:10.1017/S0266467400000110.

Irnive JE. Sugarcane. In: Chen, JCP, Chou CC, editors. Cane Sugar HandBook: a manual for cane sugar manufactures and their chemists. New York: John Wiley \& Sons, Inc., 12th ed, 1993, p. 1090.

Jenkinson HF, Lamont RJ. Oral microbial communities in sickness and in health. Trends in Microbiology. 2005. v. 13, n. 12, p. 589-595.

Jensen PS, Todd WF, Hart ME, Mickelsen RL, O'Brien DM. Evaluation and control of worker exposure to fungi in a beet sugar refinery. Am. Ind. Hyg. Assoc. J. 1993;54(12):742-748.

Jesus RS. Avaliação da formação de biofilme de fungos emergentes e sua susceptibilidade a antifúngicos na forma livre e nanocapsulada [tese]. Rio Grande do Sul: Universidade Federal do Rio Grande do Sul; 2013.

Kaneko ASN. Responses of agaric fruit-bodies to light and gravity: growth straight downward in response to light from below. Mycoscience. 2006;41(1):67 -74.

Khoury A, Atoui A. Ochratoxin A: general overview and actual molecular status. Toxins 2: 2010, p. 461-493.

Kirk PM, Cannon PF, Minter JC, \& Stalpers JA. Dictionary of the Fungi. 10th ed. Wallingford: CAB International; 2008.

Klyve GE, Oakley CG. Perseus ed. Byronic Books; 1989.

Klein V. Características agronômicas, químicas e bromatológicas de variedades de cana-de-áçucar para uso forrageiro [dissertação]. Goiás: Universidade Federal de Goiás-UFG; 2010.

Koller OC. Citricultura: Laranja, Limão e Tangerina. Porto Alegre: Rígel; 1994, p. 416.

Kosiak B, Torp M, Skjerve E, Andersen B. Alternaria and Fusarium in Norwegian grains of reduced quality: a matched pair sample study. Int. J. Food Microbiol. 2004;93(1):51-62.

Kozak PPJR, Gallup J, Cummins LH. Currently available methods for home mold surveys. II Examples of problem homes surveyed. Annals of Allergy. 1980;45(3):167-176.

Krysinska-Traczyk E, Dutkiewicz J. Aspergillus candidus: a respiratory hazard associated with grain dust. Annals of Agricultural and Environmental Medicine. 2000;7:2:101-109.

Krysisnka-Traczyk E, Pande BN, Skórska C, Sitkowska J, Prasmo Z, Cholewa G, Dutkiewicz J. Exposure of Indian agricultural workers to airborne microorganisms, dust and endotoxin during handling of various plant products. Ann Agric Environ Med. 2005;12:269-275. 
Kumar R, Kumar AV. Biodeterioration of stone in tropical environments - an overview. 1 ed. E.U.A.: J. Paul Getty Trust; 1999, p. 85.

Lacaz CDS, Porto E, \& Martins JEC. Micologia médica: fungos, actinomicetos e algas de interesse médico. Revista do Instituto de Medicina Tropical de São Paulo. 1991;33(4):332-332.

Lacaz CS, Porto E, Heins-Vaccari EM, Melo NT. Guia para identificação: fungos, actinomicetos e algas de interesse médico. São Paulo: Sarvier; 1998.

Lacaz CS, Porto E, Martins JEC, Heins-Vaccari EM, Melo NT. Tratado de Micologia Médica Lacaz. São Paulo: Sarvier; 2002. p. 1104.

Laranjeira, F.F.; Feichtengerger, E.; Bassanezi, R.B.; Spósito, M.B. Manejo integrado de doenças dos citros. In: Mattos JR., D.; De Negri, J.D.; Pio, R.M.; Pompeu JR, J. (Ed.). Citros. Campinas: Instituto Agronômico e Fundag, 2005.

Laurell AC, Noriega M. Processo de produção de saúde: trabalho e desgaste operário. São Paulo: Hucitec; 1989.

Le Bars J, Le Bars P, Dupuy J, \& Boudra H. Biotic and abiotic factors in fumonisin B1 production and stability. Journal of AOAC International. 1994;77(2):517-521.

Lee J, Taneja V, Vassallo R. Cigarette smoking and inflammation: cellular and molecular mechanisms. J. Dent. Res. 2012;91(2):142-149.

Leeuwe MR. van, Krijgsheld P, Bleichrodt R, Menke H, Stam H, Stark J, Dijksterhuis J. Germination of conidia of Aspergillus niger is accompanied by major changes in RNA profiles. Studies in Mycology. 2013;74(1):59-70. Available from: http://www.ncbi.nlm.nih.gov/pubmed/23449598.

Li WC, Zhou J, Guo SY, Guo LD. Endophytic fungi associated with lichens in Baihua mountain of Beijing, China. Fungal Diversity. 2007;25:69-80.

Lim SS, Vos T, Flaxman AD, Danaei G, Shibuya K, Adair-Rohani H, \& Aryee M. A comparative risk assessment of burden of disease and injury attributable to 67 risk factors and risk factor clusters in 21 regions, 1990-2010: a systematic analysis for the Global Burden of Disease Study 2010. The lancet. 2013;380(9859):2224-2260.

Lima MCP, Kerr-Corrêa F, Rehm J. Consumo de álcool e risco para doença coronariana na região metropolitana de São Paulo: uma análise do Projeto GENACIS. Revista Brasileira de Epidemiologia. Associação Brasileira de Pós Graduação em Saúde Coletiva; 2013. v. 16, n. 1, p. 49-57. Disponível em: http://hdl.handle.net/11449/30563.

Longo DL, Faucci AS, Kasper DL, Hauser SL et al. Medicina interna de Harrison. 18a ed. Editora: McGraw-Hill; 2013.

Lorenzi H. Plantas daninhas na cultura da cana-de -açúcar: plantas daninhas na lavoura do nordeste brasileiro. In: 4o Encontro Técnico Goal, cana-de açúcar. Recife. Anais. 1995. 
Lorian V. editor. Antibiotics in laboratory medicine, 3rd ed. Williams \& Wilkins, Baltimore, 1991.

Low CY, \& Rotstein C. Emerging fungal infections in immunocompromised patients. F1000 Medicine Reports. 2011. Available from: http://doi.org/10.3410/M3-14.

Lugauskas A, Krikstapolis A. Microscopic fungi found in the libraries of Vilnius and factors affecting their development. Indoor and Built Environment. 2004;13(3):169-182.

Lugauskas A, Krikstaponis A, Seskauskas V. Species of conditionally pathogenic micromycetes in the air of dwellings and occupational premises. Indoor and Built Environment. 2003;12(3):167-177.

Luz VG, Zangirolani LTO, Vilela RA. de G, Filho HRC. Consumo alimentar e condições de trabalho no corte manual de cana-de-açúcar no estado de São Paulo1. Saude soc. [online]. 2014, v. 23, n. 4, p. 1316-1328. [citado 26 mar. 2016]. Disponível em: http://www.scielo.br/scielo.php?script=sci_arttext\&pid=S0104$12902014000401316 \&$ Ing=en\&nrm=iso >. ISSN 0104-1290.

Machado FBP. Brasil, a doce terra: história do setor. ProCana.com. Ribeirão Preto; 2003. Disponível em: http://www.jornalcana.com.br/Conteudo/Histori adoSetor.asp. Acesso em: 12 jun. 2012.

Magalhões EM. de S. Análise da prevalência de infecção pelo Paracoccidioides brasiliensis em áreas rurais de Alfenas, Minas Gerais [dissertação]. Alfenas: Universidade Federal de Alfenas; 2013.

Maia FGM, Armesto C, Zancan WL. A, Maia JB, Abreu MS. Efeito da temperatura no crescimento micelial, produção e germinação de conídios de Colletotrichum spp. isolados de mangueira com sintomas de antracnose. Bioscience Journal. Uberlândia; 2011, v. 27, n. 2, p. 205-210.

Manginni PR. A saúde e suas relações com a biodiversidade, a pesca e a paisagem em duas comunidades de pescadores artesanais no litoral do Paraná [tese]. Paraná: Universidade Federal do Paraná; 2010.

Manginni PR, Silva JCR. Medicina da Conservação: aspectos gerais. In: Cubas ZS, Silva JCR, Catão-Dias JL. (Org.). Tratado de Animais Selvagens - Medicina Veterinária. São Paulo. 2006, v. 1, p.1258-1268. 2006.

Manguinhos do sonho à vida: a ciência na Belle Époque. Rio de Janeiro: Casa de Oswaldo Cruz; 1990.

Mantelatto P. E. Estudo do processo de cristalização de soluções impuras de sacarose de cana-de-açúcar por resfriamento [dissertação]. São Carlos: Universidade Federal de São Carlos; 2005, p. 272.

Manzano RP, Fukushima RS, Gomes JDF, Garippo G. Digestibilidade do bagaço de cana-de açúcar tratado com reagentes químicos e pressão de vapor. Revista Brasileira de Zootecnia. 2000, v. 29, n. 4, p. 1196-1204. 
Marafante LJ. Tecnologia da fabricação do álcool e do açúcar. São Paulo: Ícone; 1993, p. 148.

Marin E, Stefano J, Sinhorelli M, Mendes AN. Análise das principais micoses encontradas na rotina de um laboratório de análises clínicas na cidade de jataí, estado de Goiás, Brasil. 2014;(2):43-52.

Marin S, Velluti A, Ramos AJ, Sanchis V. Effect of essential oils on zearalenone and deoxynivalenol production by Fusarium graminearum in non-sterilized maize grain. Food Microbiol. 2004;21(3):313-318.

Martinez R. Blastomicose Sul-Americana (Paracoccidioidomicose): Etioepidemiologia e ecologia. In: Tratado de Infectologia (R. Veronesi \& R. Focaccia, org.). São Paulo: Editora Atheneu; 1996, p. 1081-1083.

Martinez R. Epidemiology of Paracoccidiomycosis. Rev. Inst. Med. trop. S. Paulo. São Paulo. 2015, v. 57, supl 19, p. 11-20. Sept. Available from $<$ http://www.scielo.br/scielo.php?script=sci_arttext\&pid=S0036-

46652015000800011\&lng=en\&nrm=iso. Accessed on: 1 Mar. 2016.

Martins-Dinis JN, da Silva RA, Miranda ET. Monitoramento de fungos anemofilos e de leveduras em unidades hospitalar. Revista de Saúde Pública. 2005;39(3):398-405.

Medina JC, Bleinroth EW, Bernhardt LW, Hashizume T. A cultura do abacaxi. In: Medina JC et al. Frutas tropicais 2. São Paulo: Canton; 1978, p. 06-68.

Meijer M, Houbraken JAMP, Dalhuijsen S, Samson RA, Vries RP. Growth and hydrolase profiles can be used as characteristics to distinguish Aspergillus niger and other black aspergilli. Studies in Mycology. 2011;69(1):19-30. Available from: http://www.ncbi.nlm.nih.gov/pubmed/21892240.

Melzer ACDS, Igutti AM. Working conditions and musculoskeletal pain among Brazilian pottery workers. Cad. Saúde Pública. Rio de Janeiro. 2010, v. 26, n. 3 Available from: http://www.scielosp.org/scielo.php?Script=sci_arttext\&pid=S0102311X2010000300007\&lng=en\&nrm=iso. Accessed on: 11 Feb. 2011.

Mendes EdePP. A produção rural familiar em Goiás: as comunidades rurais no município de Catalão [tese]. Presidente Prudente: Universidade Estadual Paulista; 2005, 296f.

Mendes S. Infeções fúngicas e dermatologia [tese]. Porto: Universidade Fernando Pessoa; 2014.

Menegat RP, Fontana RT. Condições de trabalho do trabalhador rural e sua interface com o risco de adoecer. Ciência, Cuidado e Saúde. Santo Ângelo. 2010 , v. 9 , n. 1, p. 52-59.

Menezes EA, Carvalho PG, Trindade ECPM, Sobrinho GM, Cunha FA \& Castro FFM. Airborne fungi causing respiratory allergy in patients from Fortaleza, Ceará, Brazil. Jornal Brasileiro de Patologia e Medicina Laboratorial. 2004a;40(2):79-84. 
Messner B, Bernhard D. Smoking and cardiovascular disease: mechanisms of endothelial dysfunction and early atherogenesis. Arterioscler Thromb Vasc. Biol. 2014;34(3):509-15.

Mezzari A, Perin C, Santos Jr AS, Bernd LAG, Gesu GD. Fungos anemófilos e sensibilização em indivíduos atópicos em Porto Alegre, RS. Rev Assoc Med Bras 2003;49(3):270-3.

Mills JY. Ecology of Mycotoxigenic Fusarium species on cereal seeds. J Food Potec. 1989;52:737-42.

Minas Gerais. Secretaria de Agricultura de Minas Gerais. Produção de Abacaxi de Minas Gerais. 2011. Disponível em: http://www.agricultura.mg.gov.br/noticias/707. Acesso em: 04 abr. 2011.

Minas Gerais. Secretaria de Estado de Desenvolvimento Econômico. Minas prepara mão de obra para ampliar produção de açúcar e álcool. 2009. Disponível em:

http://www.desenvolvimento.mg.gov.br/index.php?option=com_content\&task=vi ew\&id=426\&itemid=74. Acesso em: 05 abr. 2011.

Minas Gerais. Secretaria de Estado de Saúde. Relatórios de visitas técnicas em Frutal e Fronteira. 2008.

Minelli L, Neme L. Atualização em micoses superficiais. RBM rev. bras. med. 2004, v. 61, n. 5, p. 28-34.

Mims AS, Mims III FM. Fungal spores are transported long distances in smoke from biomass fires. Atmos Environ. 2004;38(9):651-5.

Mohanraj D, Padmanaban P, Viswanathan R. Biological control of sugarcane diseases. In: Gnanamanickan SS. (Ed.). Biological control of crop diseases. Chennai: CRC PRESS; 2002, p. 161-78.

Mora C, Tittensor DP, Adl S, Simpson AG, Worm B. How many species are there on Earth and in the ocean? PLoS Biol. 2011;9(8). Available from: http://journals.plos.org/plosbiology/article?id=10.1371/journal.pbio. 1001127.

Moraes LF. Gonçalo M. Tavares e os seus Senhores [tese]. São Paulo: Faculdade de Filosofia, Letras e Ciências Humanas, Universidade de São Paulo; 2012.

Morisseau C, Ward BL, Gilchrist DG, Hammock BD. Multiple epoxide hydrolases in Alternaria alternata f. sp. lycopersici and their relationship to medium composition and hostspecific toxin production. Appl Environ Microbiol. 1999;65(6):2388-95.

Morris A, Beck JM, Schloss PD, Campbell TB, Crothers K, Curtis JL, \& Jablonski $\mathrm{K}$. Comparison of the respiratory microbiome in healthy nonsmokers and smokers. American journal of respiratory and critical care medicine. 2013;187(10):1067-1075. 
Moscovici F. Desenvolvimento interpessoal: treinamento em grupo. 4a ed. Rio de Janeiro: José Olympio; 1995.

Moyes DL, Naglik JR. The mycobiome: influencing IBD severity. Cell Host Microbe. 2012;11:551-552. Available from: https://kclpure.kcl.ac.uk/portal/en/publications/the-mycobiome-influencing-ibdseverity(5296aba4-84b1-4deb-aacc-44a7cec26fed)/export.html.

Munkvold GP, McGee DC, Carlton WM. Importance of Different Pathways for Maize Kernel Infection by Fusarium moniliforme. Phytopathology. 1997, v. 87, n. 2.

Munkvold GP, McGee DC, Carlton WM. Pathways for infection of corn kernels by Fusarium moniliforme. (Abstr.) Phytopathology. 1994;84:1144.

Muñoz P, Burillo A, Bouza E. Environmental surveillance and other control measures in the prevention of nosocomial fungal infections. Clin. Microbiol Infect. 2001;7 Suppl 2:38-45.

Murray CJ, Lopez AD. Measuring the global burden of disease. New England Journal of Medicine. 2013;369(5):448-457.

Murray P, Rosenthal K, Pfealler M. Microbiologia Médica. 5a ed. Rio de Janeiro: Elsevier; 2006.

Mycology online. Disponível: http://www.mycology.adelaide.edu.au/Fungal_Descriptions/Hyphomycetes_(hya line)/Aspergillus/niger.html. Acesso em: 07 out. 2013.

Nannipieri P, AscherJ, Ceccherinni MT, Landi L, Pietramellara G, Renlle G. Microbial diversity and soil functions. European Journal of Soil Cience. Oxford. 2003 , v. 54, p. 655-670.

Nascimento MdoDSB, Leitão VMS, da Silva MACN, Maciel LB, Muniz Filho WE, Viana GMdeC et al. Eco-epidemiologic study of emerging fungi related to the work of babaçu coconut breakers in the State of Maranhão, Brazil. Rev. Soc. Bras. Med. Trop. [online]. 2014;47(1):74-78 [citado 13 abr. 2016]. Disponível em: $\quad$ http://www.scielo.br/scielo.php?script=sci_arttext\&pid=S0037$86822014000100074 \& \operatorname{lng}=$ en.

Nazario W. Revisão das micotoxicoses de interesse médico e veterinário. Biológico. 1979;45(7/8):113-22.

Nelson PE, Dignani MC, Anaissie EJ. Taxonomy, biology, and clinical aspects of Fusarium species. Clinical Microbiology Reviews. 1994. v. 7, n. 4, p. 479-504.

Neves MF, Trombin VG, Consoli M. O mapa sucroenergético do Brasil. In: Souza ELL, Macedo IC, editores. Etanol e bioeletricidade: a cana-de-açúcar no futuro da matriz energética. São Paulo: Luc Projetos de Comunicação; 2010.

Nogueira SR. Lima FSO, Rocha EM, Araujo DHM. Fungicidas no controle de fusariose do abacaxi no estado de Tocantins, Brasil. Rev. de Ciências Agrárias [online]. 2014, v. 37, n. 4, p. 447-455 [citado 10 mar. 2016]. Disponível em: 
http://www.scielo.mec.pt/scielo.php?script=sci_arttext\&pid=S0871-

018X2014000400010\&lng=pt\&nrm=iso. ISSN 0871-018X.

Novaes, JRP. Campeões de produtividade: dores e febres nos canaviais paulista. Ver. Estudos Avançados. São Paulo; 2007.

Novaes J. Quadra fechada [videocassete]. Vídeo documentário (VHS). Rio de Janeiro: IE/UFRJ; 2007. Laurell AC, Noriega M. 1989.

Nucci M, Queiroz-Telles F, Alvarado-Matute T, Tiraboschi IN, Cortes J, Zurita J, \& Echevarria JI. Epidemiology of candidemia in Latin America: a laboratorybased survey. PloS one. 2013;8(3).

Olbrich SRLR. Estudo da prevalência de fungos em travesseiros de crianças com rinite e, ou, asma [tese]. Botucatu: Universidade Estadual Paulista; 2010.

Oliveira CASD, Costa SM, Zocratto KBF, \& Branco KMGR. Avaliação microbiana da recontaminação de artigos odontológicos estéreis segundo o manuseio das embalagens. RFO UPF. 2001;16(3):256-260.

Oliveira JC. Tópicos em micologia médica. 4a ed. Rio de Janeiro: Editora Rio de Janeiro; 2014.

Oliveira KNS, Bezerra LR, Bezerra MAR, Oliveira KNS, Carneiro CT. Fadiga laboral em trabalhadores rurais. Rev Rene. 2013;14(5):866-76.

Oliveira LRR. Validação de salas limpas com o monitoramento ambiental, Montes Claros-MG [dissertação]. Montes Carlos: Faculdade de Ciência e Tecnologia de Montes Claros; 2010.

Oliveira MTB, Braz FS, Ribeiro MAG. Airbone fungi isolated from Natal, State of Rio Grande do Norte -Brazil. Rev. de Microbiologia. 1993;24(3).

Oliveira RAD. Referênciais teóricos da migração internacional e a questão da mobilidade espacial dos cortadores de cana. Rev. bras. estud. popul. São Paulo. 2014, v. 31, n. 2, p. 453-469. Disponível em: http://www.scielo.br/scielo.php?script=sci_arttext\&pid=S0102$30982014000200011 \&$ Ing=en\&nrm=iso. Acesso em: 26 mar. 2016.

Olson Cl. Fungal contamination of conjuctive and lid margin. Arch Ophthalmol. 1969;81:351-5.

Orasch C, Marchetti O, Garbino J, Schrenzel J, Zimmerli S, Mühlethaler K, Bille J. Candida species distribution and antifungal susceptibility testing according to European Committee on Antimicrobial Susceptibility Testing and new vs. old Clinical and Laboratory Standards Institute clinical breakpoints: a 6 year prospective candidaemia s. Clinical Microbiology and Infection. 2014;20(7):698705. Available from: http://doi.org/10.1111/1469-0691.12440.

Ortiz E, Ng RTY, Alliegro FC, Teixeira C, Muranaka EB, \& Sakano E. Microbiology of rhinosinusitis in immunosupressed patients from the University Hospital. Brazilian journal of otorhinolaryngology. 2011;77(4):522-525. 
Palomino MEP, Chimento M, Fernandes AAR, \& Fernandes L. A cultivar de abacaxi 'vitória'e uma proposta de indicação geográfica para o polo da região norte do estado do espírito santo. Cadernos de Prospecção. 2015;8(3):577.

Palone MRT, Silva TRD, Vieira NA, \& Dalben GDS. Sequência de Robin e suas repercussões sobre a microbiota bucal: revisão de literatura. Pediatr Mod. 2013;49(11):445-50.

Parise-Fortes MR et al. Imunologia da paracoccidioidomicose. Anais Brasileiros de Dermatologia. Rio de Janeiro, 2011, v. 86, n. 3, p. 516-525.

Pati PK, Sharma M, Salar RK, Sharma A, Gupta AP, Slingh B. Studies on leaf spot disease of Withania somnifera and its impact on secondary metabolites. Indian Journal of Microbiology. 2008;48:432-437.

Patterson TF, Kirkpatrick WR, White M, Hiemenz JW, Wingard JR, Dupont B, \& Aspergillus Study Group. Invasive Aspergillosis Disease Spectrum, Treatment Practices, and Outcomes. Medicine. 2000;79(4):250-260.

Pavón Moreno MA, González Alonso I, Martín de Santos R, \& García Lacarra T. Importancia del género Alternaria como productor de micotoxinas y agente causal de enfermedades humanas. Nutrición Hospitalaria. 2012;27(6):17721781.

Peculienel VRAH, Baulciniene I, Raapassalo M. Isolation of yeasts and enteric bacteria in root-filed teed with chronic apical periodontists. International Endodontic Journal, 2001;34:429-434.

Peleg AY, Hogan DA \& Mylonakis E. Medically important bacterial-fungal interactions. Nature Rev. Microbiol. 2010;8:340-349.

Pemán J, Salavert M. Enfermedad fúngica invasora por Scedosporium, Fusarium y Mucor. Revista Iberoamericana de Micología. 2014, v. 31, n. 4, p. 242-248.

Pereira BFP, de Melo LE, da Costa PF. Fungos anemófilos isolados na cidade de Belém, estado do Pará-Brasil. Revista Eletrônica de Biologia (REB). 2013, v. 6 , n. 1, p. 82-93.

Perfect JR, Casadevall A: Fungal molecular pathogenesis: what can it do and why do we need it? In Molecular Principles of Fungal Pathogenesis. Edited by: Heitman J, Filler SG, Edwards JE, Mitchell AP. Washington DC: ASM Press; 2006:3-12.

Perini GF, Camargo LFA, Lottenberg CL, \& Hamerschlak N. Fusariose disseminada com endoftalmite em paciente com neoplasia hematológica. Einstein. São Paulo. 2013;11(4):545-546.

Pfaller MA, Diekema DJ. Epidemiology of invasive candidiasis: a persistent public health problem. Clin Microbiol Rev. 2007;20(1):133-63. Available from: http://cmr.asm.org/content/20/1/133.full.pdf+html. 
Pfohl-Leszkowicz A, Manderville R. Ochratoxin A. An overview on toxicity and carcinogenicity in animals and humans. Molecular Nutrition \& Food Research. 2007;51:61-99.

Pinheiro ET, Gomes P, Ferraz CC, Teixeira FB, Sousa-Filho SJ. Microorganisms from canals of rood filled teeth with periapical lesions. International Endodontic Jounal. 2003;36(1):1-11.

Pinto VdeS, Galesi VMN, Fukasava S, Vicentini AP. Vigilância Epidemiológica da Paracoccidioidomicose no Estado de São Paulo, 2008 a 2011. BEPA, Bol. epidemiol. paul. [online] 2012, v. 9, n. 103, p. 04-15 [citado 30 set. 2015]. Disponible en: http://periodicos.ses.sp.bvs.br/scielo.php?script=sci_arttext\&pid=S1806$42722012000700001 \& \operatorname{lng}=e s \& n r m=i s o$.

Pires JG. Comparação dos meios de cultura e das técnicas de quantificação de bactérias e fungos em reservatórios e tubulações de água de equipos odontológicos [tese]. São Paulo: Universidade de São Paulo; 2014.

Piteira C. A qualidade do ar interior em instalações hospitalares. Lisboa: Lidel, 2007.

Pitt JI, Hocking AD. Fungi and Food Spoilage. 2nd edition. Inglaterra: Blackie Academic and Professional; 1997.

Pitt JI, Hocking AD. Fungi and Food Spoilage. Sydney: Academic Press; 1985.

Prado ML. Setor sucroalcooleiro, automação e novos gerenciamentos: novos perfis do trabalho. Estudos de Sociologia. 2011, v. 16, n. 31.

Prakash R, Jha SN. Basics of the Genus Aspergillus. International Journal of Research in Botany. 2014;4(2):26-30. Available from: http://urpjournals.com/tocjnls/30_14v4i2_2.pdf

Pranav PK, Patel T. Impact of ergonomic intervention in manual orange harvester among the workers of a hilly region in India. Work, n. Preprint, 2016, p. 1-9.

Prasad SC, Kotigadde S, Shekhar M, Thada ND, Prabhu P, D'Souza T, \& Prasad KC. Primary otomycosis in the Indian subcontinent: predisposing factors, microbiology, and classification. International journal of microbiology. 2014.

Prefeitura Municipal de Frutal. Disponível em: http://www.frutal.mg.gov.br.

Prista J, Uva AS. A utilização de indicadores biológicos em saúde ocupacional. Revista Portuguesa de Saúde Pública. 2006;6:45-54.

Proença M, Pitta F, Kovelis D, Mantoani LC, Furlanetto KC, Zabatiero J, \& Ramos EMC. Transporte mucociliar e sua relação com o nível de atividade física na vida diária em fumadores saudáveis e não fumadores. Revista Portuguesa de Pneumologia. 2012;18(5):233-238.

Querales PJ. Caracterização morfológica e genética de Fusarium spp. isolado de sementes e associados a podridão do colmo do milho (Zea mays L.) [tese]. 
São Paulo: Escola Superior de Agricultura Luiz de Queiroz, Universidade de São Paulo; 2010.

Quesada NV, Lange JH. Final clearance criteria after mould remediation. Indoor and Built Environment. 2004;13(3):199-203.

Rautiala S, Kangas J, Louhelainen K, Reiman M. AlHA Farmers' exposure to airborne microorganisms in composting swine confinement buildings. J Fairfax. Va. 2003;64(5):673-7.

Restrepo A, Gomez BL, Tobón A. Paracoccidioidomicose: Latin America's Own Fungal Disorder. Current Fungal Infection Reports. 2012, v. 6, p. 303-311.

Ribeiro CAF. Potencialidades de diferentes linhagens de levedura da espécie Saccharomyces cerevisiae na tecnologia de aguardente de cana [dissertação]. Piracicaba: Escola Superior de Agricultura Luiz de Queiroz, Universidade de São Paulo; 1997, p. 107.

Ribeiro H, Assunção JVD. Efeitos das queimadas na saúde humana. Estud. av. São Paulo. 2002, v. 16, n. 44. Disponível em: http://www.scielo.br/scielo.php?script=sci_arttext\&pid=S0103$40142002000100008 \&$ Ing=en\&nrm=iso. Acesso em: 1 fev. 2015.

Ribeiro H. Queimadas de cana-de-açúcar no Brasil: efeitos à saúde respiratória. Rev. Saúde Pública. São Paulo. 2008, v. 42, n. 2.

Ripoli TCC, Ripoli MLC. Biomassa de cana-de-açúcar. colheita, energia e ambiente. Piracicaba: Barros \& Marques Editoração Eletrônica; 2005, p. 302309.

Rivas S, Thomas CM. As interações moleculares entre o tomate e a folha moldam o pathogen: Fulvum do Cladosporium. Revisão anual de Phytopathology. 2005.43:395-436.

Robbins N, Uppuluri P, Nett J, Rajendran R, Ramage G, Lopez-Ribot JL, Cowen LE. Hsp90 governs dispersion and drug resistance of fungal biofilms. PLoS Pathogens. 2011;7(9). Available from: http://journals.plos.org/plospathogens/article?id=10.1371/journal.ppat. 1002257 .

Rocha FdaS, Ferreira GHS, Silva TCSR, Amaral FL, Muniz MdeFS, \& Pereira EA. Caracterização de Fusarium solani f. sp. piperis, produção de fitotoxina e incidência da fusariose no norte de Minas Gerais. Summa Phytopathologica. 2016;42(1):67-72. Disponivel em: https://dx.doi.org/10.1590/0100-5405/2100.

Rocha FLR, Marziale MHP, Hong O-S. Work and health conditions of sugar cane workers in Brazil. Rev. Esc. Enferm. USP [Internet]. 2010 Dec [cited 2011 May 29]; 44(4):978-983. Available [rom: http://www.scielo.br/scielo.php?script=sci_arttext\&pid=S008062342010000400017\&lng=en. Access on: 11 Feb. 2011.

Rocha FLR, Marziale MHP, Robazzi MLCC. A pobreza como fator predisponente ao adoecimento de trabalhadores do corte de cana-de-açucar. Rev. LatinoAm.Enfermagem. Ribeirão Preto. 2007, v. 15, n. spe. 
Rocha LO, Tralamazza SM, Reis GM, Rabinovitch L, Barbosa CB, \& Corrêa B. Multi-Method approach for characterizing the interaction between Fusarium verticillioides and Bacillus thuringiensis subsp. kurstaki. PloS one. 2014, v. 9, n. 4, p. e92189.

Rodrigues AG, Araujo R. Comparison of Andersen and Honey Jar methods for monitoring hospital wards. Indoor and Built Environment. 2007;16(1)71-78.

Rodrigues AN, Sobrinho J, Derdadini O, Franco JM, Rodrigues Neto JOR, Genestra M. Lesões cutâneas em mulheres colhedoras de laranja atendidas no programa de saúde da família da cidade de Planura, Minas Gerais, Brasil. Brasília Med. 2010;47(3):300-303.

Rosa LA, Navarro VL. Trabalho e trabalhadores dos canaviais: perfil dos cortadores de cana da região de Ribeirão Preto (SP) ${ }^{1}$. Cad. psicol. soc. trab. São Paulo, 2014, v. 17, n. 1, p. 143-160. Disponível em: http://pepsic.bvsalud.org/scielo.php?script=sci_arttext\&pid=S1516$37172014000200011 \& \mathrm{lng}=$ pt\&nrm=iso. Acesso em: 26 mar. 2015.

Rose CS. Bioaerosols: Assessment and Control. In: Macher J, Ammann HA, Burge HA, Milton DK, Morey PR. (ed.). American Conference of Governmental Industrial Hygienists. Cincinnati, OH, Antigens, 1999:25-11.

Rose CS, Martyny JW, Newman LS, Milton DK, King TE Jr, Beebe JL, McCammon JB, Hoffman RE, Kreiss K. Lifeguard lung: endemic granulomatous pneumonitis in an indoor swimming pool. Am. J. Public Health. 1998;88(12):1795-800.

Rosolen V, Herpin U, Melfi AJ. Expansion of hidromorphic soil cover in the southwest landscape of brasilian amazon: texture and porosity soil changes. Caminhos de Geografia. 2007, v. 8, n. 20.

Rumin CR, Navarro VL, Perioto NW. Trabalho e saúde no agrobusiness paulista: estudo com colhedores manuais de cana-de-açúcar da região oeste do Estado de São Paulo. Cad. psicol. soc. trab. 2008, vol.11, no. 2, p. 193-207. ISSN 15163717.

Rumora L, Kovacic S, Rozgai R, Cepelak I, Pepeljnjek S, Zanic, Grubisc T. Cytotoxic and genotoxic effects of fumonisin B1 on rabbit kidney RK13 cell line. Arch Toxicol. 2002;76(1):55-61.

Sabino R, Faísca VM, Carolino E, Veríssimo C, Viegas C. Occupational Exposure to Aspergillus by Swine and Poultry Farm Workers in Portugal Journal of Toxicology and Environmental Health, Part A. Current Issues. 2012, v. 75, Issue 22-23.

Sabouraud R. Contribution a l'etude de la trichophytie humaine. Etude clinique, microscopique et bacterioloqique sur la pluralite des trichophytons de l'homme. Ann. Dermatol. Syphil. 1892;3:1061-1087. 
Sadhra S, Gardiner K. Requirements of monitoring exposure to workplace contaminants. In: Sadhira S, Rampal K. ed. lit. Occupational health: risk assessment and management. London: Blackwell Science; 1999, p. 129-158.

Sahin I, Kaya D, Parlak AH, Oksuz S, Behcet M. Dermatophytoses in forestry workers and farmers. Mycoses. 2005;48(4):260-4.

Sampaio T. O tupi na geographia nacional. São Paulo: O Pensamento; 1914, p. 285.

Samson RA, Hoekstra ES, Frisvad JC, Filtenborg O. Introduction to food and airborne fungi. $6 a$ ed. Baarn: CBS; 2000, p. 389.

Samson RA, Hoekstra ES, Frisvad JC. Introduction to Food and Airborne Fungi. 7th ed. Centraalbureau voor Schimmelcultures: Utrecht, The Netherlands; 2004.

Samson RA, Houbraken J, Summerbell RC, Flannigan B, Miller JD. Common and important species of fungi and actinomycetes in indoor environments. In: Microogranisms in Home and Indoor Work Environments. New York: Taylor \& Francis; 2001, p. 287-292.

San-Blas G, Burger E. Experimental medical mycological research in Latin America - a 2000-2009 overview. Revista Iberoamericana de Micologia. Barcelona. 2011, v. 28, n. 1, p. 1-25.

San Miguel MM, Cisteró AB. Utilidad de los alergenos recombinantes de hongos en la práctica diaria. Alergol Inmunol Clin. 2003;18(3):117-21.

Santarosa, E., Koller, O. C., Casamali, B., \& Petry, H. B. Production and physicochemical quality of fruits in'Valencia'orange trees with different pruning intensities and frequencies. Revista Brasileira de Fruticultura, 2013; 35(3), 790-798.

Santo AHÇ. Tendência da mortalidade relacionada à paracoccidiomicose no Estado de São Paulo, Brasil, 1985a 2005: estudo usando causas múltiplas de morte. Rev Panam Slud Publica. Washigton. 2008, v. 23, n. 5, p. 313-324.

Santos APA, Batista SB. Isolamento e caracterização fenotípica de microorganismos isoldos de solo poluído por resíduos sólidos do bairro carrapicho município de Várzea Grande-Mato Grosso. Connection Line. 2015;12.

Schlegel HG. General microbiology. Cambridge University Press, Cambridge, 1993.

Schmidt $\mathrm{RH}$. Basic elements of equipment cleaning and sanitizing in food processing and handling operations. Florida: Institute of Food and Agricultural Sciences, University of Florida, 1997. Available from: http://edis.ifas.ufl.edu. Access on: 21 Jun. 2014.

Scopinho RA. Condições de vida e saúde do trabalhador em assentamento rural. Ciênc. saúde coletiva. Rio de Janeiro. 2010, v. 15, supl. 1, p. 15751584. em: http://www.scielo.br/scielo.php?script=sci_arttext\&pid=S1413-

$81232010000700069 \&$ Ing=en\&nrm=iso. Acesso em: 22 set. 2015. 
Scopinho RA. Vigiando a vigilância: saúde e segurança no trabalho em tempos de qualidade total. São Paulo: Annablume-Fapesp; 2003.

Scriban R. Biotecnologia. São Paulo: Manole; 1985, p. 488.

Scwartman S. Um Espaço para a Ciência: a formação da comunidade científica no Brasil. Segunda parte. Ministério da Ciência e Tecnologia, Brasília, 2001. Disponível em: http://www.schwartzman.org.br/simon/spacept/espaco.htm. Acesso em: 10 jun. 2013.

Secretaria de Minas e Energia. Minas Gerais. 2010. Disponível em: http://www.mme.gov.br/

Serra LH, Araújo M. A terminologia da cana-de-açúcar no Brasil na perspectiva do agricultor e do agrônomo: oralidade e escrita em questão. Debate Terminológico. 2011, n. 13, p. 54-66. ISSN: 1813-1867.

Shoenlein-Crusis I, Paula C. Adolph Lutz e a micologia. In: Dermatologia e Micologia. Benchimol, Jaime e SÁ, Magali (orgs). Rio de Janeiro: Editora Fiocruz; 2004, p. 25-33.

Shoham S. Emerging fungal infections in solid organ transplant recipients. Infectious disease clinics of North America. 2013, v. 27, n. 2, p. 305-316.

Sidrin JJC, Rocha MFC. Micologia Médica: a luz de autores contemporâneos. Rio De Janeiro: Guanabara Koogan; 2004.

Silva ARP. As transformações socioespaciais de Frutal-MG [dissertação]. Uberlândia: Universidade Federal de Uberlândia; 2012, 172 f. il.

Simão S. O abacaxizeiro. In: Simão S. Tratado de fruticultura. Piracicaba: FEALQ; 1998, p. 249-288.

Simões RJ, Fonseca P, Figueiral MH. Infecções por Candida spp na Cavidade Oral. Odontol. Clín.-Cient. [online]. Recife. 2013, v. 12, n. 1, [citado mar. 2013]. Disponível em: http://revodonto.bvsalud.org/scielo.php?script=sci_arttext\&pid=S1677$38882013000100004 \&$ Ing=pt\&nrm=iso. Acesso em: 01 out. 2015.

Simpson DP. Cassell's Latin Dictionary. 5a ed. London: Cassell Ltd; 1979, p. 883. ISBN 0-304-52257-0.

Singh AB, Alka S, Pandit T. Respiratory diseases among agricultural industry workers in India: a cross-sectional epidemiological study. Ann Agric Environ Med. 1999;6:115-126.

Singh AB. Pollen and Fungal Aeroallergens Associated with Allergy and Asthma in India. Global Journal of Immunology and Allergic Diseases. 2014;2:19-28.

Soriano JM, Dragacci S. Intake, decontamination and legislation of fumonisins in foods. Food Research International. 2004;37(4):367-374. 
Sorensen LK, Elbaek TH. Determination of mycotoxins in bovine milk by liquid chromatography tandem mass spectrometry. J Chromatogr B Analyt Technol Biomed Life Sci. 2005;820(2):183-196. doi:10.1016/j.jchromb.2005.03.020.

Sousa JP, Franco MH, Rodrigues MA. Riscos dos agentes biológicos. Lisboa: IDICT; 2001.

Stanzani M, Tumietto F, Vianelli N, Baccarani M. Update on the treatment of disseminated fusariosis: focus on voriconazole. Therapeutics and clinical risk management. 2007;3(6):1165.

Steenkamp ET, Wingfield BD, Coutinho TA, Wingfield MJ, Marasas WFO. Differention of Fusarium subglutinans f.sp. pini by tristone gene sequence data. Applied and Environmental Microbiology. Washington. 1999, v. 65, n. 8, p. 34013406.

Steele DB, Stowers MK. Techniques for selection of industrially important microorganisms. Annual Review of Microbiology. 1991, v. 45, p. 89-106.

Stelmach R, Fernandes FLA, Carvalho-Pinto RM, Athanazio RA, Rached SZ, Prado GF, Cukier A. Comparison between objective measures of smoking and self-reported smoking status in patients with asthma or COPD: are our patients telling us the truth? Jornal Brasileiro de Pneumologia. 2015;41(2):124-132.

Stuart RM. Comunidade de fungos endofíticos associada à cana-de-açúcar convencional e geneticamente modificada [tese]. Piracicaba: Escola Superior de Agricultura Luiz de Queiroz, Universidade de São Paulo; 2006.

Sweeney J, Dobson ADW. Mycotoxin production by Aspergillus, Fusarium and Penicillium species. International Journal of Food Microbiology. 1998, v. 43, p. 141-158.

Távora LG, Gambale W, Heins-Vaccaril EM. Comparative performance of two air samplers for monitoring airborne fungal propagules. Brazilian Journal of Medical and Biological Research. 2003;36(5)613-616.

Taylor TN, Taylor EL. The distribution and interactions of some Paleozoic fungi. Review of Palaeobotany and Palynology. 1996;95(1-4):83-94.

Telles MR, Saran LM, Uneda SH. Produção, propriedades e aplicações de bioplástico obtido a partir da cana-de-açúcar. Ciência e Tecnologia. 2011;2(1):52-63.

Tessari CA. A escassez sazonal de mão de obra na agricultura e o trabalhador nacional: nem vadio, nem escasso, nem instável. Oeste paulista. 1890-1915. 2011.

Tessari CA. O padrão de demanda por mão de obra na lavoura paulista e a questão do trabalhador nacional: nem vadio, nem escasso, nem instável (18901915). Economia e Sociedade. 2015, v. 23, n. 2, p. 465-487. 
Thomaz Júnior A. Por trás dos canaviais, os "nós" da cana: a relação capital x trabalho e o movimento sindical dos trabalhadores na agroindústria canavieira paulista. São Paulo: editora Annablume; 2002.

Tokesshi H. Doenças da cana-de-açúcar (híbridos de Saccharum spp.). In: Kimati H, Amorin L, Bergamin Filho A, Camargo LEA, Rezende JAM. (eds.). Manual de Fitopatologia. São Paulo: Editora Agronômica Ceres; 1997. v. 2, p. 207-225.

Torelo L. Treinamento técnico-operacional. In: Boog GG. (org.). Manual de Treinamento e Desenvolvimento. São Paulo: McGraw-Hill; 1980, p. 503.

Tortora GJ, Funke BR, Case CL. Microbiologia. 6a ed. Porto Alegre: Artmed editora; 2002.

Tsai SM, Yang CS, Crandal MS. Measurements of airborne fungal and endotoxin levels in waterdamaged buildings. Indoor Air Quality Moisture, Microbes, and Heath Effects: Indoor Air Quality and Moisture in Buildings; 2001.

Trabulsi LR, Altathum F, Gompertz OF, Candeias JAN. Microbiologia. 3a ed. São Paulo: Atheneu; 1999, p. 421-422.

Tremaroli V, Backhed F. Functional interactions between the gut microbiota and host metabolism. Nature. 2012;489:242-9.

Underhill DM, lliev ID. The mycobiota: interactions between commensal fungi and the host immune system. Nature Publishing Group. 2014;14(6):405-416. doi:10.1038/nri3684

União de Indústrias de cana-de-açúcar (ÚNICA). 2009. Disponível em: http://www.unica.com.br/

Ursell LK, Metcalf JL, Parfrey LW, Knight R. Defining the human microbiome. Nutrition reviews. 2012;70(suppl 1):S38-S44.

Vello LS. Saúde do trabalhador na atenção primária à saúde: estudo de caso em um município na região metropolitana de São Paulo [tese]. São Paulo: Universidade de São Paulo; 2015.

Ventura JA, Zambolim L, Gilbertson RL. Proposição de nova forma specialis em Fusarium subglutinans no abacaxizeiro. Resumo. Fitopatologia Brasileira. 1993, v. 18, p. 280.

Verzignassi JR, Santos MdeF, Matos APde, Benchimol RL, Poltronieri LS. Fusariose do abacaxizeiro no Pará. Summa Phytopathologica. 2009;35(4):329$330 . \quad$ Disponível em: http://www.scielo.br/scielo.php?script=sci_arttext\&pid=S0100$54052009000400014 \&$ Ing=en\&tIng=pt.10.1590/S0100-54052009000400014. Acesso em: 23 set. 2015.

Viera. Genetic instability of sugarcane plants derived from meristem cultures. Genetic Molecular Biology. 2002;25(1):91-96. 
Vieira LA, Belfort Júnior RB, Fischman OF, Scarpi M. Estudo da flora fúngica da conjuntiva normal, da cana-de-açúcar e de anemófilos da regiäo canavieira de Santa Rita, Paraíba, Brasil. Arq. bras. Oftalmol. 1989;52(3):63-7.

Vilas Boas SW, Dias EC. Impactos sobre a Saúde do Trabalhador - Contribuição para a discussão sobre as políticas no setor sucro-alcooleiro e as repercussões sobre a saúde dos trabalhadores. In: Impactos da indústria canavieira no Brasil. 2005. Plataforma BNDES. IBASE - Versão preliminar. p. 23-35. Disponível em: http://www.plataformabndes.org.br. Acesso em: 28 nov. 2014.

Vilas Boas SW. O setor sucroalcooleiro na microrregião de Frutal - Iturama, Minas Gerais: suas características e reflexos na saúde dos cortadores de cana [dissertação]. Rio de Janeiro: Escola Nacional de Saúde Pública Sergio Arouca, Fundação Oswaldo Cruz; 2009.

Vilela RADG, Santos SAD, Silva AJND, Almeida IMD. Surveillance experience in the sugarcane sector: challenges in disrupting the perilous "marathon" of the sugarcane plantations. Ciência \& Saúde Coletiva. 2014;19(12):4659-4668.

Vishwakarma SK, Kumar P, Nigam A, Singh A, Kumar A. Pokkah boeng: An emerging disease of sugarcane. J Plant Pathol Microb. 2013;4(170):2.

Wade WG. The oral microbiome in health and disease. Pharmacological research. 2013, v. 69, n. 1, p. 137-143.

Wadhwani K, Scrivastava KA. Fungi from otites media of agricultural field Works. Mycophatology. 1894;88:155-159.

Watling R. The Role of Amateur in Micology - What would we do without them! In: Mycoscience. Springer Japan. 1998, v. 39, n. 4, p. 1618- 2545.

Winstone HVF, Howard C. Descoberta da Tumba de Tutancâmon. Constable, 1991.

Zhicheng S, Pangcheng L. Extrinsic allergic alveolitis. In: Work-related Lung Disorders. Blackwells. 1986, p. 320-344.50.

Zukiewicz-Sobczak WA, Chmielewska-Badora J, Wróblewska P, Zwoliński J. Farmers' occupational diseases of allergenic and zoonotic origin. Postep Derm Alergol. 2013;30(5):311-315. 